\title{
10. HIGH-RESOLUTION NEOGENE PLANKTONIC FORAMINIFER BIOSTRATIGRAPHY OF SITE 806, ONTONG JAVA PLATEAU (WESTERN EQUATORIAL PACIFIC) ${ }^{1}$
}

\author{
William P. Chaisson ${ }^{2}$ and R. Mark Leckie ${ }^{2}$
}

\begin{abstract}
The Neogene biostratigraphy presented here is based on the study of 230 samples through $737 \mathrm{~m}$ of pelagic sediment in Hole 806B. Sediment accumulation is interrupted only once in the uppermost lower Miocene (Zone N6), apparently coincident with a widespread deep-sea hiatus. Preservation of planktonic foraminifers through the section ranges from good to moderately poor. One hundred and ten species of planktonic foraminifers were identified; taxonomic notes on most species are included. All of the standard low-latitude Neogene foraminiferal zones are delineated, with the exceptions of Zones N8 and N9 because of a high first occurrence of Orbulina, and Zones N18 and N19 because of a high first occurrence of Sphaeroidinella dehiscens.

Good agreement exists between the published account of the variation in planktonic foraminiferal species richness and the rates of diversification and turnover, and measurements of these evolutionary indexes in the record of Hole 806B. The global pattern of change in tropical/transitional species richness is paralleled in Hole 806B, with departures caused by either ecological conditions peculiar to the western equatorial Pacific or by inexactness in the estimation of million-year intervals in Hole 806B.

Temporal changes in the relative abundance of taxa in the sediment assemblages, considered in light of their depth habitats, reveal a detailed picture of historical change in the structure of the upper water column over the Ontong Java Plateau. The dominance of surface dwellers (Paragloborotalia kugleri, P. mayeri, Dentoglobigerina altispira, Globigerinita glutinata, and Globigerinoides spp.) throughout the lower and middle Miocene is replaced by a more equitable distribution of surface $(D$. altispira and Globigerinoides spp.), intermediate (Globorotalia menardii plexus), and deep (Streptochilus spp.) dwellers in the late Miocene, following the closing of the Indo-Pacific Seaway and the initiation of large-scale glaciation in the Antarctic. The shoaling of the thermocline along the equator engendered by these climatic and tectonic events persisted through the Pliocene, when initial increases in the abundance of a new set of shallow, intermediate, and deep dwelling species of planktonic foraminifers coincide with the closing of the Panamanian Seaway.
\end{abstract}

\section{INTRODUCTION}

One of the principal objectives of Ocean Drilling Program (ODP) Leg 130 was to collect a depth transect of complete Neogene sections down the northeastern flank of Ontong Java Plateau in the western equatorial Pacific (Fig. 1). The goal was to evaluate the vertical distribution of a variety of parameters of paleoceanographic significance (Kroenke, Berger, Janecek, et al., 1991). Site 806 anchors this transect near the top of the plateau in a water depth of $2520 \mathrm{~m}$. Hole $806 \mathrm{~B}$ contains the thickest $(738 \mathrm{~m})$ and most complete Neogene sequence drilled during Leg 130 (Kroenke, Berger, Janecek, et al., 1991). The pelagic sediments of Hole $806 \mathrm{~B}$ contain rich assemblages of calcareous and siliceous microfossils and represent a rare opportunity to further refine biostratigraphies and the correlation between microfossil groups in an expanded, virtually complete tropical section. The section also provides a wealth of material for high-resolution sedimentologic, isotopic, geochemical, geophysical, and physical properties analyses. The absence of a paleomagnetic stratigraphy in all but the upper $10 \mathrm{~m}$ (Kroenke, Berger, Janecek, et al., 1991) is the only disappointing feature of this section, particularly from a geochronologic point of view.

Neogene planktonic foraminifers have been widely studied in the subtropical and tropical Pacific (e.g., Brönnimann and Resig, 1971; Jenkins and Orr, 1972; Keller, 1981a, 1981b, 1981c; Orr and Jenkins, 1980; Srinivasan and Kennett, 1981a, 1981b; Barron et al., 1985; Saito, 1985; Stone and Keller, 1985). The purpose of this study is twofold. First, we establish a high-resolution planktonic foraminiferal biostratigraphy through the Neogene of Hole 806B. This provides a

\footnotetext{
'Berger, W.H., Kroenke, L.W., Mayer, L.A., et al., 1993. Proc. ODP, Sci. Results, 130: College Station, TX (Ocean Drilling Program).

${ }^{2}$ Department of Geology and Geography, University of Massachusetts, Morrill Science Center, Amherst, MA 01003, U.S.A.
}

chronostratigraphic framework for sedimentologic, geochemical, and geophysical research at this site. Second, we evaluate the species concepts and morphologic variability of low-latitude taxa, and then document taxon ranges and compare Hole $806 \mathrm{~B}$ datums with other published records, including nearby Deep Sea Drilling Project (DSDP) Hole 289. The ranges of the 110 species encountered in this study provide a large data base for the study of species richness and rates of speciation, extinction, and turnover in the tropics.

We present 228 samples from the basal Miocene through Pleistocene of Hole $806 \mathrm{~B}$ and two additional samples from the uppermost Oligocene of Hole $806 \mathrm{C}$. The Neogene ( $0-23.7 \mathrm{Ma}$ ) of Hole $806 \mathrm{~B}$ is represented by $737.75 \mathrm{~m}$ of section. This translates into an average sample density of approximately 31 samples per $100 \mathrm{~m}$ of section with an average temporal resolution of about 104 k.y. In addition, we examined numerous additional samples to refine biostratigraphic datums. For example, in the Miocene/Pliocene boundary interval, the average temporal resolution is approximately $22.6 \mathrm{k} . \mathrm{y}$.

\section{METHODS}

A total of 230 samples from Cores $130-806 \mathrm{~B}-1 \mathrm{H}$ through $-78 \mathrm{X}$ (0-743.1 mbsf) and Cores 130-806C-59X and -60X (740.0-759.2 mbsf) were examined in detail for planktonic foraminifers. Most cores are represented by three samples, typically from Sections 2, 5, and the core catcher (CC). Cores with poor recovery are represented by one or two samples, depending on the amount of sediment recovered. The relative abundances of planktonic foraminiferal species in these 230 samples are shown on the distribution table (Table 1, in back pocket). Additional samples, typically from Sections 1, 3, 4, and 6, were examined for key taxa or to more closely resolve the placement of biostratigraphic boundaries. These samples are not shown on the distribution table.

Samples were soaked in a neutral $\mathrm{pH}$ mixture of diluted hydrogen peroxide and Calgon for about an hour. The samples began to get 


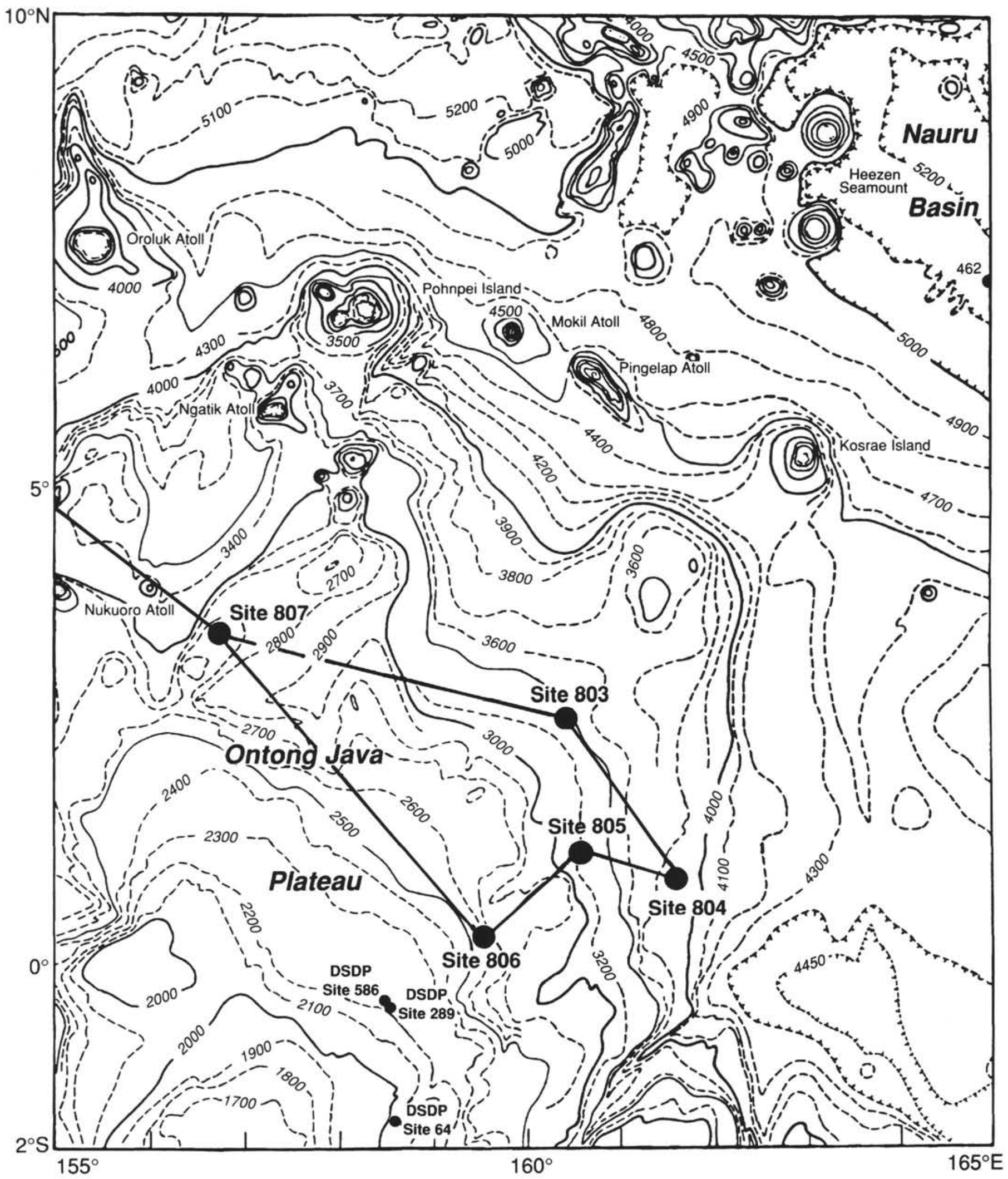

Figure 1. Bathymetric map of the Ontong Java Plateau and adjacent basins. Legs 130 sites are indicated by large dots connected by the ship track. Earlier DSDP sites are indicated by smaller dots. Contour intveral is $1000 \mathrm{~m}$. 
chalky below $200 \mathrm{mbsf}$, and the sediment consisted of all chalk below 530 mbsf. Chalky samples were ultrasonicated for 10-15 s. Small bits of chalk were carefully squeezed between the finger tips to enhance disaggregation. This physical manipulation did not result in enhanced breakage of foraminiferal tests. The disaggregated sediment was washed over a $63-\mu \mathrm{m}$ sieve. The samples were then dried in an oven at approximately $100^{\circ} \mathrm{C}$. Nearly all samples below $530 \mathrm{mbsf}$ had to be washed twice to completely free the foraminiferal tests from the chalky matrix.

The dried sediment was sprinkled on a picking tray, and individual specimens were picked and mounted on a gummed population slide. All samples were examined at least twice. Relative abundance data were based on the $>63-\mu \mathrm{m}$ fraction, although in many samples the $>250,150-250$, and $63-150 \mu \mathrm{m}$ fractions were also examined for rare species. Three categories of foraminiferal species abundance were recorded: rare $(<5 \%)$, few $(5 \%-15 \%)$, and common $(>15 \%)$. Foraminiferal preservation was based on a qualitative assessment of the degree of test breakage and/or dissolution: good (minimal breakage), moderately good $(10 \%-30 \%$ breakage, minor etching on susceptible species), moderate $(30 \%-50 \%$ breakage, significant etching on susceptible species), and moderately poor (50\%-70\% breakage, etching on thick-walled species). The relative abundance of radiolarians and benthic foraminifers in the sediment assemblages was also estimated.

\section{LITHOSTRATIGRAPHY OF SITE 806}

Site 806 was drilled in a water depth of $2520 \mathrm{~m}$ on the northeastern margin of the Ontong Java Plateau $\left(0^{\circ} 19.1^{\prime} \mathrm{N}, 159^{\circ} 21.7^{\prime} \mathrm{E}\right)$, approximately $125 \mathrm{~km}$ northeast of DSDP Sites $289 / 586$ (Kroenke, Berger, Janecek, et al., 1991). Hole 806B cored the entire Neogene sequence (Cores 130-806B-1H to -78X; 0-743.1 mbsf), although drilling was stopped in the Oligocene/Miocene boundary interval. The boundary was not recovered in Hole $806 \mathrm{~B}$ because of poor recovery in Core $130-806 \mathrm{~B}-78 \mathrm{X}$, the lowest core in this hole. Hole $806 \mathrm{C}$ cored through the boundary interval. The Oligocene/Miocene boundary is placed between Cores 130-806B-78X-CC and 130-806C-59X-CC, at approximately $738 \mathrm{mbsf}$, based on planktonic foraminiferal evidence.

A total of $776.4 \mathrm{~m}$ was cored at Holes $806 \mathrm{~B}$ and $806 \mathrm{C}$. Two lithologic subunits were recognized. Subunit IA $(0-339 \mathrm{mbsf})$ is composed of foraminifer nannofossil ooze to nannofossil ooze with foraminifers. Subunit IB (339-776.4 mbsf) is composed of foraminifer nannofossil chalk to nannofossil chalk with foraminifers. The first signs of sediment induration (chalk) occur at approximately $200 \mathrm{mbsf}$. The ooze-chalk transition is placed at approximately 339 mbsf (at the boundary between Subunits IA and IB). Below $530 \mathrm{mbsf}$, the sediment is composed entirely of chalk and is well lithified. In a gross sense, the foraminifer content of the sediments is relatively low in the upper Oligocene and lower Miocene, highest in the middle Miocene, low again in the upper Miocene, and relatively high through the Pliocene and Pleistocene based on qualitative shipboard smear slide analysis through the entire sequence and quantitative grain-size analyses throughout Subunit IA (Kroenke, Berger, Janecek, et al., 1991). No obvious correlation exists between relative foraminifer abundance and sedimentation rate.

The entire sequence is moderately to heavily bioturbated. Two thin beds of well-sorted foraminifer ooze are noted at 39.4 and $45.1 \mathrm{mbsf}$ in Hole $806 \mathrm{C}$. Several centimeter-size porcellanite nodules are recorded in Holes 806B and 806C at approximately 240, 315, 350, 509, and 514 mbsf. None of these horizons correspond with planktonic foraminiferal biostratigraphic boundaries. With the exception of one condensed interval in the lower Miocene (Zone N6, approximately $580 \mathrm{mbsf}$ ), no evidence exists of interruption, hiatus, or significant reworking other than bioturbation.

\section{BIOSTRATIGRAPHY AND ZONAL CRITERIA}

We largely follow the zonal scheme of Blow (1969) as emended by Srinivasan and Kennett (1981a, 1981b) and Kennett and Srinivasan (1983), including the subdivision of Zones N4 and N17, and the use of the last occurrence (LO) of Globorotalia fohsi s.l. to define the Zone N12/N13 boundary. We have further emended this scheme in two ways (Fig. 2). First, following Berggren et al. (1985a, 1985b) and Berggren and Miller (1988), we use the first occurrence (FO) of Paragloborotalia kugleri s.s. to define the top of Zone P22/base of Subzone N4a (Oligocene/Miocene boundary), instead of the FO of Globigerinoides primordius (Bolli, 1957; Blow, 1969; Bolli and Premoli Silva, 1973; Bolli and Saunders, 1985) or the FO of Globoquadrina dehiscens (Kennett and Srinivasan, 1983). Keller (1984) subdivided Zone N4 into three subzones based on the successive first occurrences of P. kugleri, Globigerinoides triloba s.1., and G. dehiscens. However, specimens of the genus Globigerinoides are very rare in the basal Miocene of Hole $806 \mathrm{~B}$, and this prohibits the application of these subzonal criteria. Leckie et al. (this volume) record the FO of $G$. primordius at or near the base of upper Oligocene Zone P22 in the western North Atlantic, casting further doubt on the reliability of the "Globigerinoides datum" in the low latitudes. Second, because Blow's "Globorotalia pseudopima" was not differentiated from Neogloboquadrina dutertrei in this study, we could not recognize Zone N20 in the mid-Pliocene. Instead, we used a widespread mid-Pliocene coiling change in species of Pulleniatina (sinistral to dextral), dated at $3.8 \mathrm{Ma}$ (Berggren et al., 1985b), to subdivide Zone N19.

\section{Zone N22/N23}

Age: latest Pliocene to Holocene.

Definition: Total range of Globorotalia truncatulinoides.

Discussion: Blow (1969) differentiated Zones N23 and N22 on the FO of Globigerinella calida calida in the late Pleistocene. However, in Hole 806B, G. calida s.l. is rare, and we recognize it below the FO of $G$. truncatulinoides and therefore cannot differentiate Zone N23 as proposed by Blow (1969). Likewise, Kennett and Srinivasan (1983) report a range of early Pliocene (N19) to Holocene for G. calida.

The Pliocene/Pleistocene boundary, approximated by the LO of Globigerinoides fistulosus and dated at 1.6 Ma (Berggren et al., 1985b), is in Core 130-806B-5H-2. The LO of Globorotalia tosaensis is in Core 130-806B-2H-CC.

Occurrence in Hole 806B: Cores 130-806B-6H-5 to the top of the hole (52.0-0 mbsf).

\section{Zone N21}

Age: late Pliocene.

Definition: Interval from the FO of Globorotalia tosaensis to the FO of Globorotalia truncatulinoides.

Occurrence in Hole 806B: Cores 130-806B-9H-2 to $-6 \mathrm{H}-6$ (75.5-52.0 mbsf).

\section{Zone N19(part)/N20}

Age: mid-Pliocene.

Emended definition: Interval from the mid-Pliocene coiling change in species of Pulleniatina (from sinistral to dextral) to the FO of Globorotalia tosaensis.

Discussion: Blow's (1969) original concept of Zone N20 could not be recognized in Hole 806B. Globorotalia miocenica is used in the Atlantic, Gulf of Mexico, and Caribbean as a mid-Pliocene marker taxon (Bolli, 1970; Berggren, 1973; Bolli and Premoli Silva, 


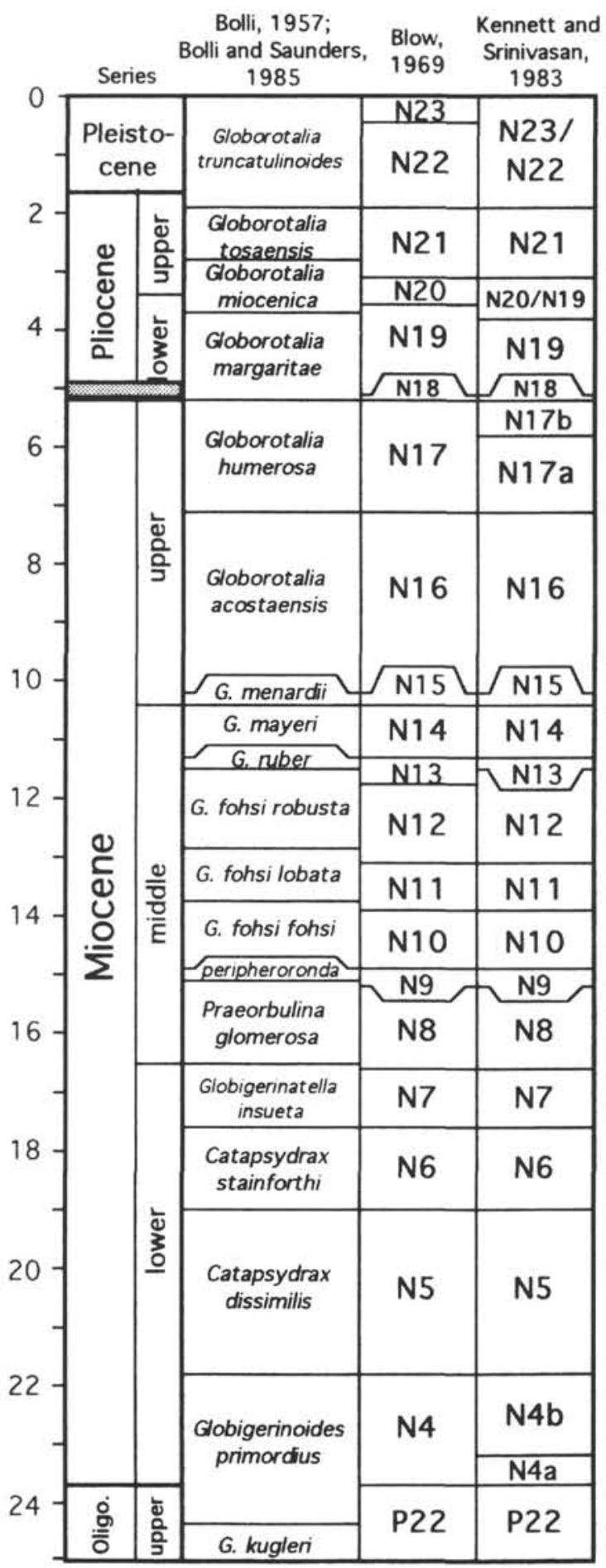

Datums used in this study

(from Berggren et al., 1985b)

FO G. truncatulinoides (1.9 Ma)

FO G. tosaensis ( $3.1 \mathrm{Ma}$ )

Coiling change in Pulleniatina (3.8 Ma)

FO S. dehiscens s.I. (5.1 Ma)

FO G. tumida ( $5.2 \mathrm{Ma})$

FO P. primalis $(5.8 \mathrm{Ma})$

FO G. plesiotumida (7.1 Ma)

FO N. acostaensis (10.2 Ma)

LO G. mayeri (10.4 Ma)

FO G. nepenthes (11.3 Ma)

LO G. fohsi s.I. (11.5 Ma)

FO G. fohsi s.I. (13.1 Ma)

FO G. praefohsi (13.9 Ma)

FO G. peripheroacuta (14.9 Ma)

FO Orbulina spp. (15.2 Ma)

FO P. sicana (16.6 Ma)

LO C. dissimilis (17.6 Ma)

FO G. insueta (19.0 Ma)

LO G. kugleri (21.8 Ma)

FO G. dehiscens (23.2 Ma)

FO G. kugleri (23.7 Ma)

Figure 2. Zonal scheme, zonal marker species, and absolute ages used in this study.

1973), but it is absent in the Pacific. The widespread coiling change in all species of Pulleniatina is a convenient way to subdivide Zone $\mathrm{N} 19$ into mid-Pliocene and lower Pliocene parts in the tropical Pacific. In Hole 806B, the LO of Globorotalia margaritae is in Core 130-806B-9H-5 and the LO of Sphaeroidinellopsis spp. is in Core 130-806B-9H-3.

Occurrence in Hole 806B: Cores $130-806 \mathrm{~B}-12 \mathrm{H}-1$ to $-9 \mathrm{H}-3$ (102.5-75.5 mbsf).

\section{Zone N18/N19 Undifferentiated}

Age: early Pliocene.

Definition: Interval from the FO of Globorotalia tumida to the mid-Pliocene coiling change in Pulleniatina (sinistral to dextral).

Discussion: The FO of Sphaeroidinella dehiscens s.1. is used to differentiate Zone N18 and Zone N19 (Blow, 1969; Srinivasan and Kennett, 1981a, 1981b; Kennett and Srinivasan, 1983). However, the 
FO of $S$. dehiscens s.l. in Hole $806 \mathrm{~B}$ is anomalously high (Core $130-806 \mathrm{~B}-10 \mathrm{H}-\mathrm{CC})$ by reference to other lower Pliocene datums, thereby prohibiting differentiation of these two zones at this site.

The LO of Globoquadrina dehiscens (Core 130-806B-18H-7) is above the FO of Globorotalia tumida. A similar stratigraphic overlap was observed by Srinivasan and Kennett (1981a, 1981b) in nearby DSDPSite 289. The FO of Globorotalia margaritae (Core 130-806B$19 \mathrm{H}-1$ ) is also just above the FO of G. tumida in Hole 806B.

Occurrence in Hole 806B: Cores 130-806B-19H-3 to $-12 \mathrm{H}-2$ (172.0-102.5 mbsf).

\section{Subzone N17b}

Age: latest Miocene.

Definition: Interval from the FO of Pulleniatina primalis to the FO of Globorotalia tumida.

Occurrence in Hole 806B: Cores 130-806B-22H-CC to $-19 \mathrm{H}-4$ (206.1-172.0 mbsf).

\section{Subzone N17a}

Age: late Miocene.

Definition: Interval from the FO of Globorotalia plesiotumida to the FO of Pulleniatina primalis.

Occurrence in Hole 806B: Cores $130-806 \mathrm{~B}-29 \mathrm{H}-3$ to $-23 \mathrm{H}-1$ (296.7-206.1 mbsf).

\section{Zone N16}

Age: late Miocene.

Definition: Interval from the FO of Neogloboquadrina acostaensis to the FO of Globorotalia plesiotumida.

Occurrence in Hole 806B: Cores 130-806B-38X-4 to $-29 \mathrm{H}-4$ (354.7-296.7 mbsf).

\section{Zone N15}

Age: early late Miocene.

Definition: Interval from the LO of Paragloborotalia mayeri to the FO of Neogloboquadrina acostaensis.

Occurrence in Hole 806B: Cores 130-806B-39X-4 to -38X-CC (364.4-354.7 mbsf).

\section{Zone N14}

Age: latest middle Miocene.

Definition: Interval from the FO of Globigerina nepenthes to the LO of Paragloborotalia mayeri.

Occurrence in Hole 806B: Cores 130-806B-40X-CC to $-39 \mathrm{X}-5$ (378.0-364.4 mbsf).

\section{Zone N13}

Age: middle Miocene.

Definition: Interval from the LO of Globorotalia fohsi s.l. to the FO of Globigerina nepenthes.

Occurrence in Hole 806B: Cores $130-806 \mathrm{~B}-44 \mathrm{X}-3$ to $-41 \mathrm{X}-2$ (411.3-378.0 mbsf).

\section{Zone N12}

Age: middle Miocene.

Definition: Total range of Globorotalia fohsi s.l.

Discussion: The species concept of Globorotalia fohsi s.l. includes all members of the fohsi group that are fully carinate with an imperforate band and/or a thin keel. This includes $G$. fohsi fohsi, $G$. fohsi lobata, and $G$. fohsi robusta.
Occurrence in Hole 806B: Cores $130-806 \mathrm{~B}-48 \mathrm{X}-2$ to $-44 \mathrm{X}-4$ (449.9-411.3 mbsf).

\section{Zone N11}

Age: middle Miocene.

Definition: Interval from the FO of Globorotalia praefohsi to the FO of Globorotalia fohsi s.1.

Occurrence in Hole 806B: Cores 130-806B-51X-CC to $-48 \mathrm{X}-5$ (483.5-449.9 mbsf).

\section{Zone N10}

Age: middle Miocene.

Definition: Interval from the FO of Globorotalia peripheroacuta to the FO of Globorotalia praefohsi.

Occurrence in Hole 806B: Cores $130-806 \mathrm{~B}-53 \mathrm{X}-\mathrm{CC}$ to $-52 \mathrm{X}-2$ (500.4 483.5 mbsf).

\section{Zone N8/N9 Undifferentiated}

Age: early middle Miocene.

Definition: Interval from the FO of Praeorbulina sicana s.s. to the FO of Globorotalia peripheroacuta.

Discussion: The FO of Orbulina spp. is used to differentiate Zones N8 and N9. In Hole 806B, Orbulina is not found below the uppermost part of Zone N10 (Core 130-806B-52X-2), making differentiation of these two zones impossible at this site.

Occurrence in Hole 806B: Cores 130-806B-59X-5 to $-54 \mathrm{X}-1$ (558.2-500.4 mbsf).

\section{Zone N7}

Age: late early Miocene.

Definition: Interval from the LO of Catapsydrax dissimilis to the FO of Praeorbulina sicana s.s.

Occurrence in Hole 806B: Cores 130-806B-61X-4 to $-59 \mathrm{X}-6$ (575.2-558.2 mbsf).

\section{Zone N6}

Age: early Miocene

Definition: Interval from the FO of Globigerinatella insueta to the LO of Catapsydrax dissimilis.

Occurrence in Hole 806B: Cores 130-806B-62X-1 to $-61 \mathrm{X}-5$ (580.3-575.2 mbsf).

\section{Zone N5}

Age: early Miocene.

Definition: Interval from the LO of Paragloborotalia kugleri to the FO of Globigerinatella insueta.

Occurrence in Hole 806B: Cores 130-806B-68X-CC to -62X-2 (642.7-580.3 mbsf).

\section{Subzone N4b}

Age: early Miocene.

Definition: Interval from the FO of Globoquadrina dehiscens to the LO of Paragloborotalia kugleri.

Occurrence in Hole 806B: Cores 130-806B-77X-CC to -69X-1 (728.9-642.7 mbsf).

\section{Subzone N4a}

Age: earliest Miocene. 
Table 2. Planktonic foraminiferal datums in Hole 806B and their stratigraphic positions.

\begin{tabular}{|c|c|c|c|c|c|c|c|}
\hline Datum & $\begin{array}{c}\text { Stratigraphic } \\
\text { Position } \\
\end{array}$ & $\begin{array}{l}\text { Age } \\
(\mathrm{Ma})\end{array}$ & \multicolumn{2}{|c|}{ Core, section. interval (cm) } & \multicolumn{2}{|c|}{ Depth (mbsf) } & $\begin{array}{c}\text { Interpolated } \\
\text { Depth } \\
\end{array}$ \\
\hline LO Globigerinoides fistulosus s.s. & Plio-Pleistocene boundary & 1.6 & $5 \mathrm{H}-1,32-34$ & $5 \mathrm{H}-2,32-34$ & 35.32 & 36.80 & 36.06 \\
\hline LO Dentogiobigerina attispira & & 2.9 & $8 \mathrm{H}-4,29-31$ & $8 \mathrm{H}-5,29 \cdot 31$ & 68.29 & 69.79 & 69.04 \\
\hline FO Globigerinoides fistulosus s.s. & & 2.9 & $8 H \cdot 6.29 \cdot 31$ & $8 H \cdot 7,29-31$ & 71.29 & 72.79 & 72.04 \\
\hline LO Sphaeroidinellopsis & & 3.0 & $9 H-2.29-31$ & $9 H-3,29-31$ & 74.79 & 76.29 & 75.54 \\
\hline LO Globorotalia margaritae & & 3.4 & $9 \mathrm{H}-4,29-31$ & 9 H.5. 29.31 & 77.79 & 79.29 & 78.54 \\
\hline$\triangle$ Pulleniatina & Base N19-20/top N18-N19 & 3.8 & $12 \mathrm{H}-1,30-32$ & $12 \mathrm{H}-2.30-32$ & 101.80 & 103.30 & 102.55 \\
\hline LO Pulleniatina spectabilis & & 3.9 & 12H-5. 29-31 & $12 \mathrm{H} \cdot \mathrm{CC}$ & 107.79 & 111.00 & 109.40 \\
\hline FO Globorotalia tumida & Base N18-N19/top N17b & 5.2 & $19 \mathrm{H}-3,29-31$ & $19 \mathrm{H}-4,29-31$ & 171.29 & 172.79 & 172.04 \\
\hline FO Pulleniatina & Base N17b/top N17a & 5.8 & $22 \mathrm{H}-\mathrm{CC}$ & $23 \mathrm{H}-1,30-32$ & 206.00 & 206.30 & 206.15 \\
\hline FO Globorotalia plesiotumida & Base N17a/top N16 & $7+1$ & $29 \mathrm{H}-3,30-32$ & $29 \mathrm{H}-4,30-32$ & 296.00 & 297.50 & 296.75 \\
\hline FO Neogloboquadrina acostaensis & Base N16/top N15 & 10.2 & $38 \times-4, \quad 32-34$ & $38 \mathrm{x}-\mathrm{CC}$ & 353.92 & 355.43 & 354.68 \\
\hline LO Paragloborotalia mayeri & Base N15/lop N14 & 10.4 & $39 \times-4,32-34$ & $39 \times-5 . \quad 32-34$ & 363.62 & 365.12 & 364.37 \\
\hline FO Globigerina nepenthes & Base N14/top N13 & 11.3 & $40 \mathrm{x} \cdot \mathrm{CC}$ & $41 X-2 . \quad 34-36$ & 375.96 & 380.04 & 378.00 \\
\hline LO Globorotalia fohsi s.l. & Base N13/top N12 & 11.5 & $44 X-3, \quad 34-36$ & $44 X-4.34-36$ & 410.54 & 412.04 & 411.29 \\
\hline FO Globorotalia fohsi s.l. & Base N12/top N11 & 13.1 & $48 X-2, \quad 34-36$ & $48 \times-5, \quad 34-36$ & 447.64 & 452.14 & 449.89 \\
\hline FO Globorotalia praefohsi & Base N11/top N10 & 13.9 & $51 X \cdot C C$ & $52 X-2 . \quad 31-33$ & 482.60 & 484.41 & 483.51 \\
\hline Fo Globoquadrina dehiscens & Base N4b/top N4a & 23.2 & $77 \mathrm{X} \cdot \mathrm{cc}$ & $78 \mathrm{X}-1, \quad 30-32$ & 724.05 & 733.70 & 728.87 \\
\hline FO Paragloborotalia kugleri & Base N4a/top P22 & 23.7 & $78 \mathrm{x} \cdot \mathrm{CC}$ & $59 x-\mathrm{CC}$ & 734.70 & 740.81 & 737.75 \\
\hline
\end{tabular}

Notes: Reference is to $\mathrm{N}$ zones and series boundaries as defined in this paper, sample interval, and depth in the hole. Absolute ages are from Berggren et al. (1985b).

Definition: Interval from the FO of Paragloborotalia kugleri to the FO of Globoquadrina dehiscens.

Occurrence in Hole 806B: Cores 130-806B-78X-CC to -78X-1 (737.7-728.9 mbsf).

\section{Zone P22}

Age: late Oligocene.

Definition: Interval from the LO of Paragloborotalia opima to the FO of Paragloborotalia kugleri.

Occurrence in Hole 806C: Cores 130-806C-62X-CC (bottom of hole) to $-59 \mathrm{X}-\mathrm{CC}$ (776.4-737.7 mbsf),

\section{PLANKTONIC FORAMINIFERAL DATUMS}

The ages of planktonic foraminiferal datums (first and last occurrences) used in this study are from Berggren et al. (1985b) (Table 2). These ages were used to construct an age vs. depth plot of the section, and to calculate rates of speciation, extinction, and turnover per million-year interval. In a later section, we compare Hole $806 \mathrm{~B}$ speciation, extinction, and turnover rates with the global rates of Wei and Kennett (1986), who also used the datums of Berggren et al. (1985b). We have estimated ages of additional datums in Hole 806B by interpolation along the sedimentation rate curve (Table 3 ). Selected first and last occurrence datums in Hole 806B are shown in Figure 3.

The planktonic foraminiferal biostratigraphy of ODP Site 806 is very similar to that of nearby DSDP Site 289 (Srinivasan and Kennett, 1981a, 1981b). However, several taxa are present whose FOs or LOs do not correlate between the two sites (Fig. 4). For example, the FOs of Globorotalia birnageae, Sphaeroidinellopsis seminulina, Globorotalia menardii, and Globigerinoides conglobatus, and the LOs of Globorotalia birnageae, "Neogloboquadrina" continuosa, and Globigerina woodi all differ significantly between Sites 289 and 806 . We attribute these discrepancies primarily to minor differences in taxonomic interpretation between workers. The stratigraphic ranges of some taxa in Hole 806B also differ somewhat from the ranges of Kennett and Srinivasan (1983) and Bolli 
Table 3. Estimated datums derived graphically by interpolating between planktonic foraminiferal datums.

\begin{tabular}{|c|c|c|c|c|}
\hline & Datum & Core, section & $\begin{array}{l}\text { Depth } \\
\text { (mbsf) }\end{array}$ & $\begin{array}{l}\text { Age } \\
\text { (Ma) }\end{array}$ \\
\hline LO & Globlgerina apertura & $5 \mathrm{H}-5$ & 41.52 & 1.7 \\
\hline LO & Globigerina woodi & $6 \mathrm{H}-5$ & 51.23 & 1.9 \\
\hline LO & Globigerina decoraperta & $7 \mathrm{H}-2$ & 56.15 & 2.2 \\
\hline FO & Globigerina rubescens & $9 \mathrm{H}-2$ & 82.50 & 3.5 \\
\hline LO & Pulleniatina spectabllilis & $12 \mathrm{H}-2$ & 111.00 & 3.9 \\
\hline LO & Globigerina nepenthes & $13 \mathrm{H}-2$ & 112.80 & 3.95 \\
\hline LO & Globorotalia plesiotumida & $13 \mathrm{H}-5$ & 117.30 & 4.0 \\
\hline FO & Pulleniatina spectabilis & $15 \mathrm{H}-5$ & 136.29 & 4.3 \\
\hline LO & Globorotalia cibaoensis & $15 \mathrm{H}-\mathrm{CC}$ & 139.50 & 4.5 \\
\hline LO & Neogloboquadrina acostaensis & $16 \mathrm{H} \cdot 5$ & 145.79 & 4.6 \\
\hline LO & Globorotalia Manai & $17 \mathrm{H}-\mathrm{CC}$ & 158.50 & 4.9 \\
\hline LO & Globoquadrina baroemoenensis & $18 \mathrm{H}-2$ & 160.30 & 4.95 \\
\hline LO & Globoquadrina dehiscens & $18 \mathrm{H}-\mathrm{CC}$ & 168.00 & 5.1 \\
\hline FO & Globorotalia margaritae & $19 \mathrm{H}-1$ & 168.29 & 5.15 \\
\hline FO & Globoquadrina cunglomerata & $19 \mathrm{H}-5$ & 174.29 & 5.3 \\
\hline LO & Globorotalia lenguaensis & $20 \mathrm{H}-5$ & 183.79 & 5.5 \\
\hline FO & Globorotalia cibaoensis & $29 \mathrm{H}-5$ & 269.30 & 6.7 \\
\hline FO & Globorotalia Nuanai & $31 \mathrm{H}-2$ & 283.82 & 6.8 \\
\hline FO & Candeina nttida & $31 \mathrm{H}-2$ & 283.82 & 6.8 \\
\hline FO & Globigerinoides extremus & $31 \mathrm{H}-5$ & 288.32 & 6.9 \\
\hline FO & Globigerina apertura & $40 x-5$ & 374.82 & 11.0 \\
\hline LO & Globorotalia praemenardif & $40 x-5$ & 374.82 & 11.0 \\
\hline FO & Globigerina decoraperta & $42 x-2$ & 389.72 & 11.3 \\
\hline FO & Globorotalia lenguaensis & $46 \times-C C$ & 436.00 & 12.5 \\
\hline LO & Globorotalia Dirnageae & $51 \times-2$ & 475.09 & 13.7 \\
\hline LO & Globorotalia praescttula & $51 \times-5$ & 479.65 & 13.75 \\
\hline LO & Globorotalia archeomenardif & $52 X-C C$ & 490.33 & 14.3 \\
\hline FO & Globorotalia praemenardil & $54 X-2$ & 503.71 & 15.1 \\
\hline FO & Globorotalia archeomenardii & $56 X-2$ & 523.15 & 15.6 \\
\hline LO & Globigerinoides altiapertura & $59 \times-2$ & 552.00 & 16.4 \\
\hline FO & Globorotalia praescitula & $63 \times-2$ & 590.8 & 19.4 \\
\hline LO & Globoquadrina binalensis & $63 \times-2$ & 590.80 & 19.4 \\
\hline FO & Globoquadrina binalensis & $71 x-3$ & 669.10 & 22.2 \\
\hline FO & Globorotalla birnageae & $71 \mathrm{x}-\mathrm{CC}$ & 670.28 & 22.25 \\
\hline
\end{tabular}

Note: Planktonic foraminiferal datums from Berggren et al. (1985b) along the sedimentation rate curve (Fig. 6).

and Saunders (1985) (Fig. 5). Again, we attribute the discrepancies to differences in the interpretation of species concepts and the accepted range of morphologic variability by the three groups of workers. Taxonomic discussions are provided in a later section. Diachroneity may also be responsible for observed differences in stratigraphic ranges (e.g., Dowsett, 1988, 1989; Hess et al., 1989).

\section{SEDIMENTATIONRATES AND HIATUSES}

The Neogene (0-23.7 Ma) of Hole $806 \mathrm{~B}$ is represented by approximately $737.7 \mathrm{~m}$ of pelagic ooze and chalk with an average sedimentation rate of $31.1 \mathrm{~m} / \mathrm{m}$.y. However, sedimentation rates were not constant through the section based on a plot of age vs. depth (Fig. 6). The planktonic foraminiferal datums, ages, and stratigraphic positions used to construct the age vs. depth curve for Hole 806B are presented in Table 2. The ages of planktonic foraminiferal first (FO) and last (LO) occurrences are from Berggren et al. (1985b). Inherent uncertainties are present in the ages determined for individual planktonic foraminiferal datums. Datums continue to be revised with improved correlation between biostratigraphy and magnetostratigraphy, and with graphic correlation. Dowsett $(1988,1989)$ has recently shown that many late Neogene planktonic foraminiferal and calcareous nannofossil events are diachronous by more than $0.2 \mathrm{Ma}$. Taking the above into account, changes in apparent sedimentation rates depicted here reflect general trends, based on this particular set of planktonic foraminiferal datums, and considering that we have not corrected for compaction.

Six intervals of relatively constant sedimentation rates are apparent on the age vs. depth plot (Fig. 6). One striking feature of this plot is the very high sedimentation rates for the uppermost Miocene through lower Pliocene (Subzone N17a through Zone N19). Berger et al. (this volume) calculated mass accumulation rates for the Neogene of Site 806 based on these planktonic foraminiferal datums and the calcareous nannofossil datums of Takayama (this volume). They also found changing accumulation rates throughout the section, with particularly high rates through the uppermost Miocene and lower Pliocene interval. The relationship between planktonic foraminiferal zones (this study) and calcareous nannofossil zones (Takayama, this volume) in Hole 806B is shown in Figure 7.

The Neogene sedimentary record is punctuated by hiatuses at most deep-sea sites that have been examined (e.g., Keller and Barron, 1983, 1987). Of the ten widespread Neogene hiatuses (Keller and Barron, 1987) only NH1b (Zones N6 and lower N7) is unambiguously represented, as what is probably a condensed interval, in the stratigraphic record of Hole 806B. This agrees well with the record of Site 289, located $125 \mathrm{~km}$ to the southwest of Site 806 , where both NH1b and $\mathrm{PHa}$ are detectable (Keller and Barron, 1983, 1987). Hiatus NH1 represents the most significant erosional event of the Miocene (Keller and Barron, 1983, 1987). This hiatus is thought to have been caused by the opening of the Drake Passage, the subsequent initiation of deep circum-Antarctic circulation, and the reorganization of bottom-water flow. Keller and Barron (1987) divide the event into two parts (NH1a: upper Zone N4 to lower Zone N5, and NHIb: Zones N6 to lower N7). Hiatus NH1b was the more corrosive event and the cause of the removal of much of Zone N6 in Hole 806B. Globigerinatella insueta and Catapsydrax dissimilis occur together in only two samples, and foraminiferal preservation below the FO of Globigerinatella insueta is moderately poor, documenting the rise of the lysocline preceding the complete removal of sediments. On the depth vs. age plot (Fig. 6), the apparent sedimentation rate between the FO of Globigerinatella insueta and the LO of Catapsydrax dissimilis (Zone N6) is only 3.1 $\mathrm{m} / \mathrm{m}$.y., approximately an eighth of the rates above and below.

A second condensed interval may be present in the mid-Pliocene of Hole 806 where the LO of Globorotalia margaritae (3.4 Ma), the LO of Sphaeroidinellopsis (3.0 Ma), and the FO of Globorotalia tosaensis (3.1 $\mathrm{Ma}$ ) all fall within a short interval of Core 130-806B-9H (Table 2). This corresponds with Hiatus NH8 and may be associated with the closing of the Panamanian Seaway (Keller and Barron, 1987; Barron, 1989).

\section{PLANKTONIC FORAMINIFERAL SPECIES RICHNESS}

It is necessary to count specimens in a sample to measure species diversity (Buzas, 1979). In this study, however, abundance was assessed only qualitatively in the course of doing the biostratigraphy. Species richness, a tally of the number of species in each sample, is presented in Figure 8 as a rough measure of diversity, that is, without reference to measurement of dominance or equitability. A first-order pattern is immediately evident. The number of species increases from 13 in the two samples in uppermost Oligocene Zone P22 to a peak of 26 in lower Miocene Zone N6. A drastic decline in lower Miocene 


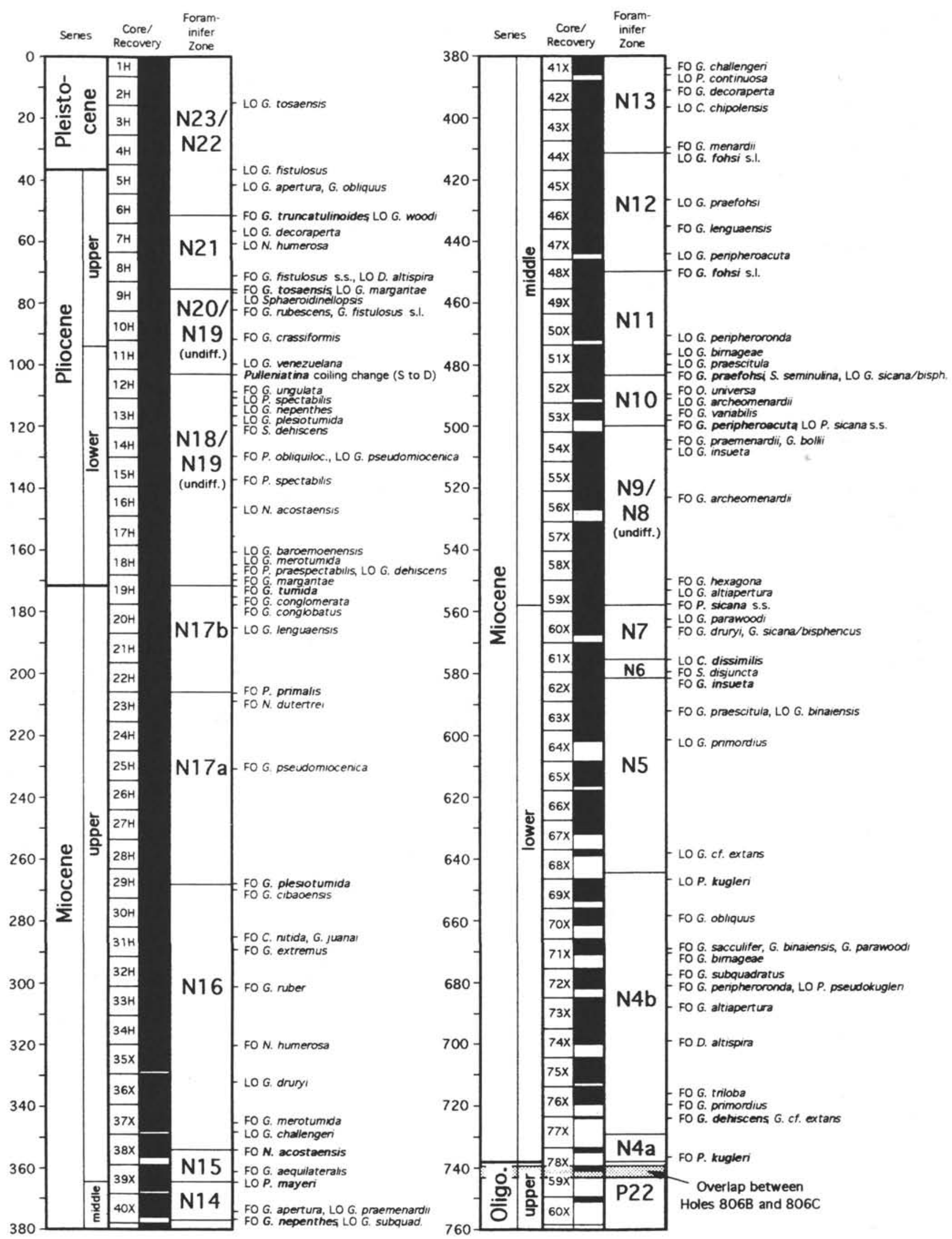

Figure 3. Selected planktonic foraminiferal first and last occurrences are indicated with reference to depth and core number in Holes 806B and 806C. Core recovery is indicated in black. 


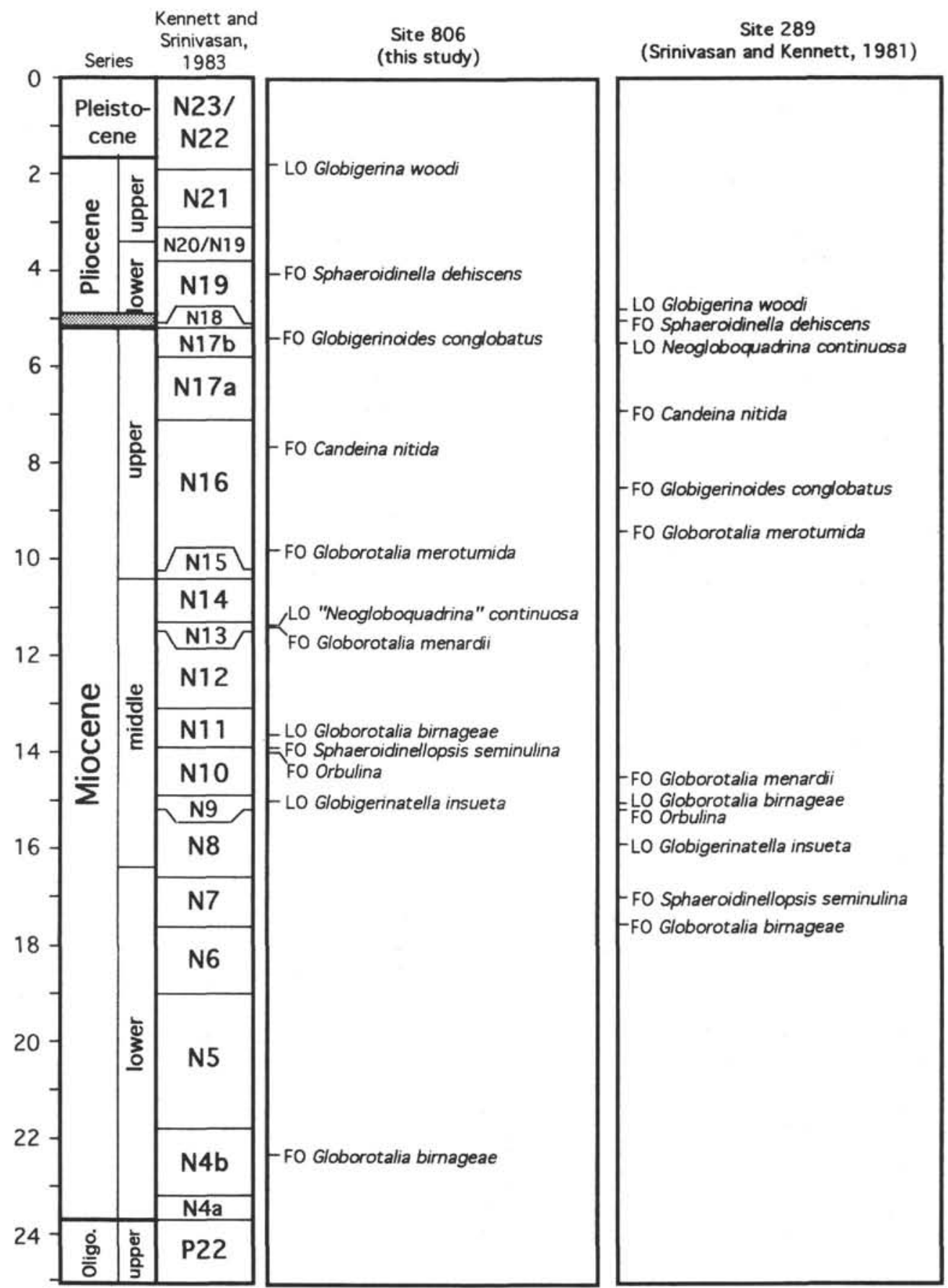

Figure 4. Comparison of first and last occurrences of planktonic foraminiferal species at Site 806 and DSDP Site 289. Only species at significant variance are shown.

Zone N7 is followed by a slight recovery and a stable interval where species richness oscillates around 21 per sample upsection through uppermost middle Miocene Zone N14. From upper Miocene Zone N15 through Subzone N17a, the number of species per sample increases before suffering another drastic decline in uppermost Miocene Subzone N17b. In lower Pliocene Zone N18/N19, the level of richness recovers to Subzone N17a values. The count then oscillates around 28 species per sample from lower Pliocene Zone N18/N19 to upper Pliocene Zone N21. Finally, a decline occurs throughout uppermost Pliocene-Pleistocene Zone N22/N23.

The drastic declines in species richness that are observed in lower Miocene Zone N7 and uppermost Miocene Subzone N17b in Hole
$806 \mathrm{~B}$ correspond to large global turnovers (i.e., the rate of extinction plus the rate of speciation) of planktonic foraminiferal species (Wei and Kennett, 1986) (Table 4 and Figs. 9-10). The global turnover of planktonic foraminifers in the world ocean is associated with episodes of climatic cooling that initiated significant ice-sheet growth in Antarctica (Haq, 1980, 1984; Kennett et al., 1985; Wei and Kennett, 1986).

Using the equations presented by Wei and Kennett (1986), turnover rates were calculated from the Site 806 data (Fig. 10). Turnover events at Site 806 are generally correlated with the global trends but are smaller. All species present throughout each million-year interval were counted. The million-year intervals in Site 806 were estimated 


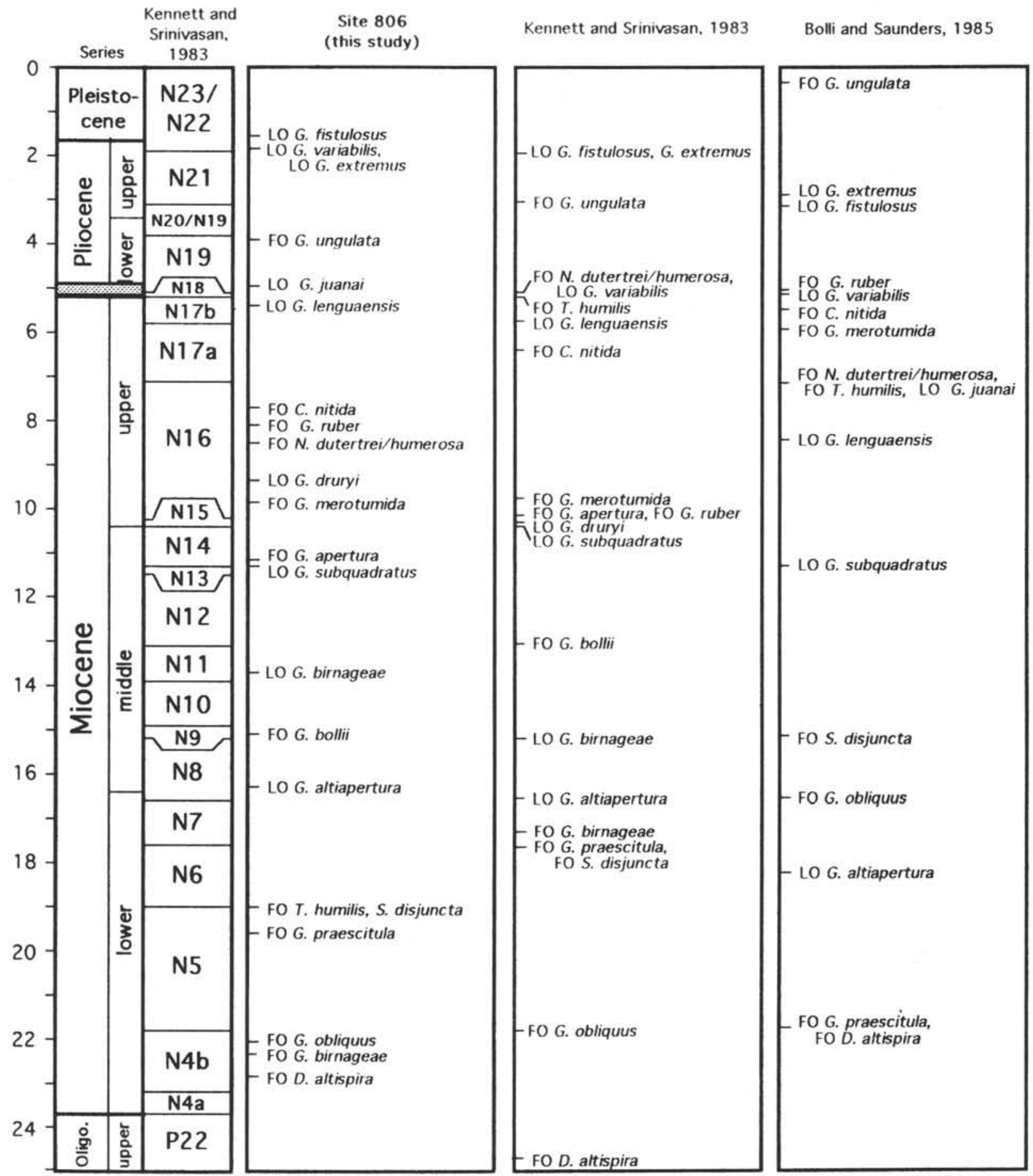

Figure 5. Comparison of first and last occurrences of planktonic foraminiferal species between Hole 806B and global stratigraphic ranges published by Kennett and Srinivasan (1983) and Bolli and Saunders (1985).

based on calculated sedimentation rates and interpolation between the planktonic foraminiferal datums of Berggren et al. (1985b). Wei and Kennett (1986) also used the datums of Berggren et al. (1985b).

The rates of diversification (i.e., the rate of speciation minus the rate of extinction) were also calculated at million-year intervals and compared to the global trends described by Wei and Kennett (1986) (Fig. 9). The global curve shows acmes of diversification to be responsible for the high turnover rates near the lower/middle Miocene boundary and in the uppermost Miocene. The site curve shows a slower increase in the rate of diversification across the lower/middle Miocene boundary. The rate of diversification is negative in the uppermost Miocene through Pleistocene in the western equatorial Pacific, that is, more extinctions occur than speciations in this interval.

Some of the species ranges documented in Hole 806B are different from globally synthesized ranges (Fig. 5), perhaps largely because of subtle differences in taxonomic interpretations. Some of the differences in ranges may be ecological rather than evolutionary in origin and may indicate the existence of physical and biological paleo- 


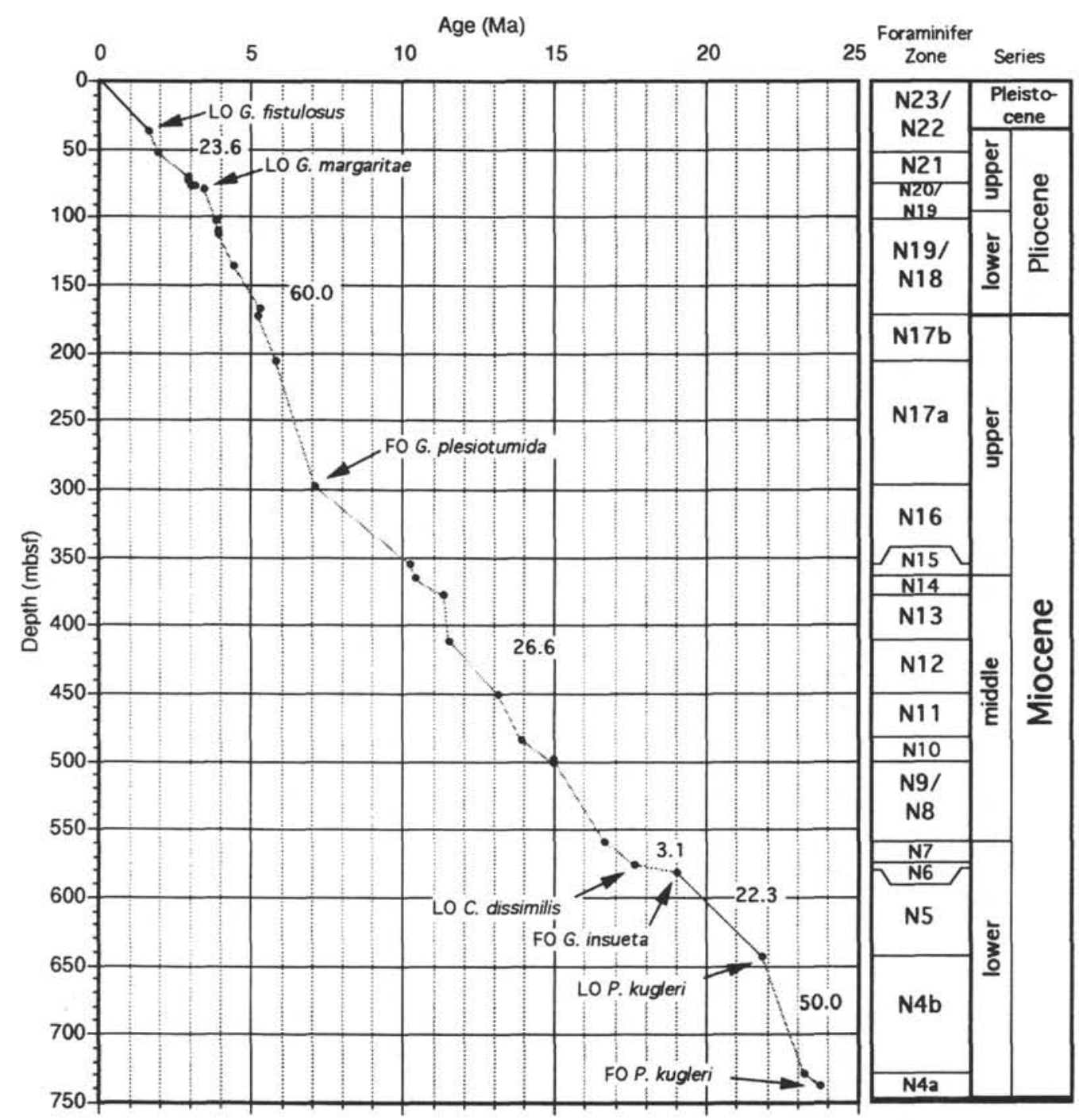

Figure 6. Depth vs. age plot of sedimentation rates in Hole 806B. Data points used to construct this curve are presented in Table 2.

ceanographic conditions peculiar to the western equatorial Pacific. This may also explain the apparent diachroneity observed in some taxa (e.g., Dowsett, 1988, 1989).

When species richness is averaged to show the number of species present through million-year intervals, a different pattern is evident. The positive excursion in the Hole 806B diversification curve that begins between 11 and $10 \mathrm{Ma}$ (middle Miocene/upper Miocene boundary, Zones N15 and N14) is associated with a rise in species richness (Fig. 9). Diversification becomes negative between 6 and 5 Ma (uppermost Miocene Zone N17b), but species richness per million-year interval attains a maximum value in this interval. This apparent artifact is explained by reference to Figure 10, where turnover rates show a very positive excursion between 6 and $5 \mathrm{Ma}$; that is, within a million-year interval, a large number of species are appearing and disappearing, but fewer co-occur in the same sample (Fig. 8).

\section{PLANKTONIC FORAMINIFERAL PALEOECOLOGY}

Planktonic foraminiferal sediment assemblages display significant variations in the relative abundances of individual species and of three depth stratified groups (cf. Keller, 1985) through the Neogene section of Hole 806B. Some species thought, on the basis of isotopic evidence (Barrera et al., 1985; Keller, 1985), to have similar "depth habitats" display sequential acmes of abundance. In other cases, extinction events are quickly followed by marked increases in taxa thought to share similar ecologic niches, or by first appearances of new taxa thought to have filled the niches left vacant by the extinctions. These examples of successive turnover may be related to competitive exclusion and adaptive radiation within a relatively stable oceanographic regime and/or to physical oceanographic changes in the structure of the upper water column, particularly to changes in the position of the thermocline relative to the euphotic zone and the position of the chlorophyll maximum. Surface dwellers are those taxa that spend most of their life cycles in the mixed layer above the thermocline. Intermediate dwellers are those taxa that spend most of their life cycles along the thermocline, whereas deep dwellers live at the base of the thermocline or below (Bé, 1977; Fairbanks and Wiebe, 1980; Fairbanks et al., 1982; Hemleben et al., 1989; Ravelo et al., 1990).

In the basal Miocene (Subzones N4a and N4b) of Hole 806B in the western equatorial Pacific, Paragloborotalia kugleri dominates the sediment assemblages. Paragloborotalia mayeri, Globoquadrina altispira, and species of Globigerinoides are rare. In the eastern 


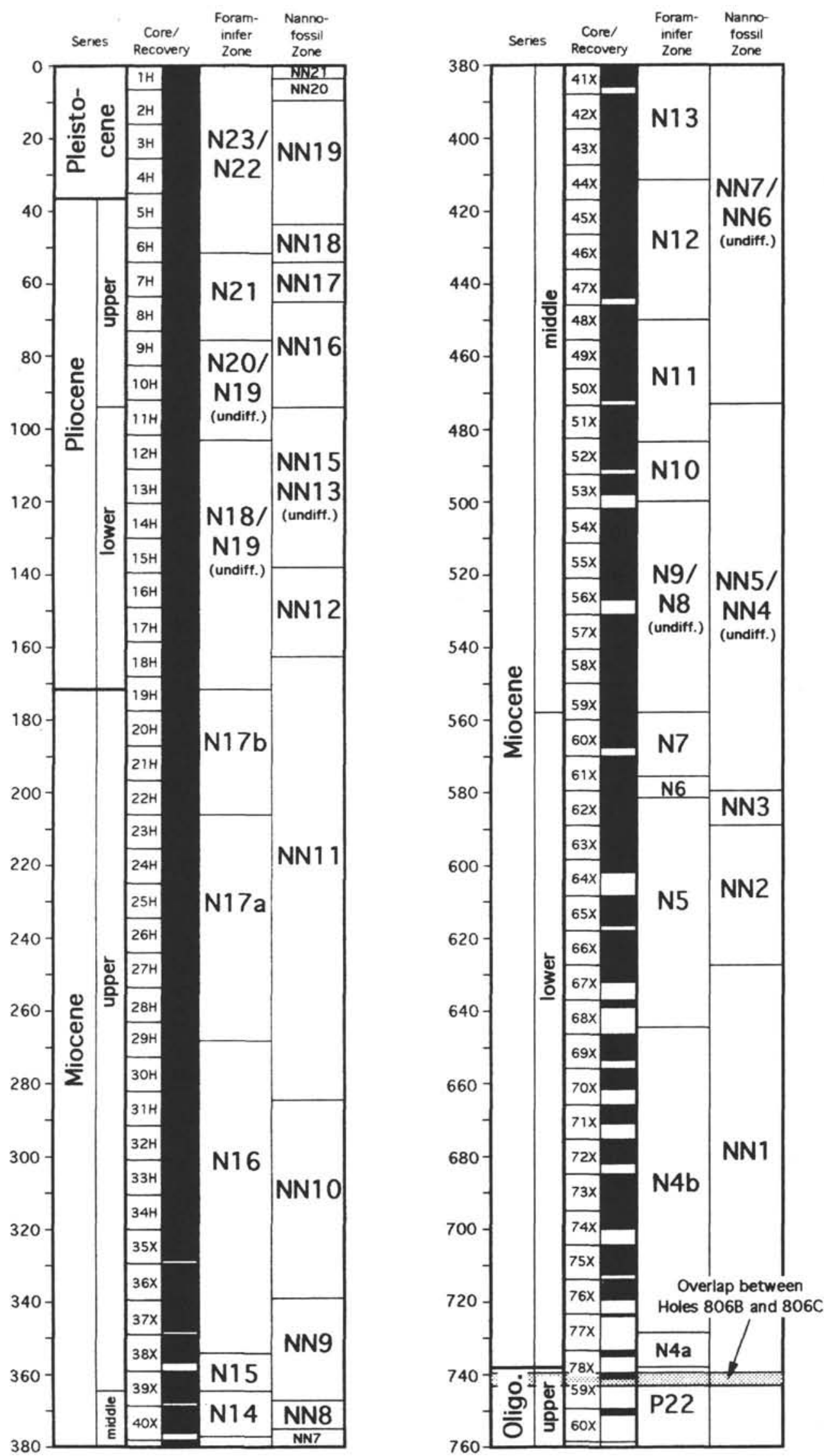

Figure 7. Comparison of planktonic foraminiferal zones (this study) and nannofossil zones (Takayama, this volume) determined in Hole 806B with reference to depth in the hole. 


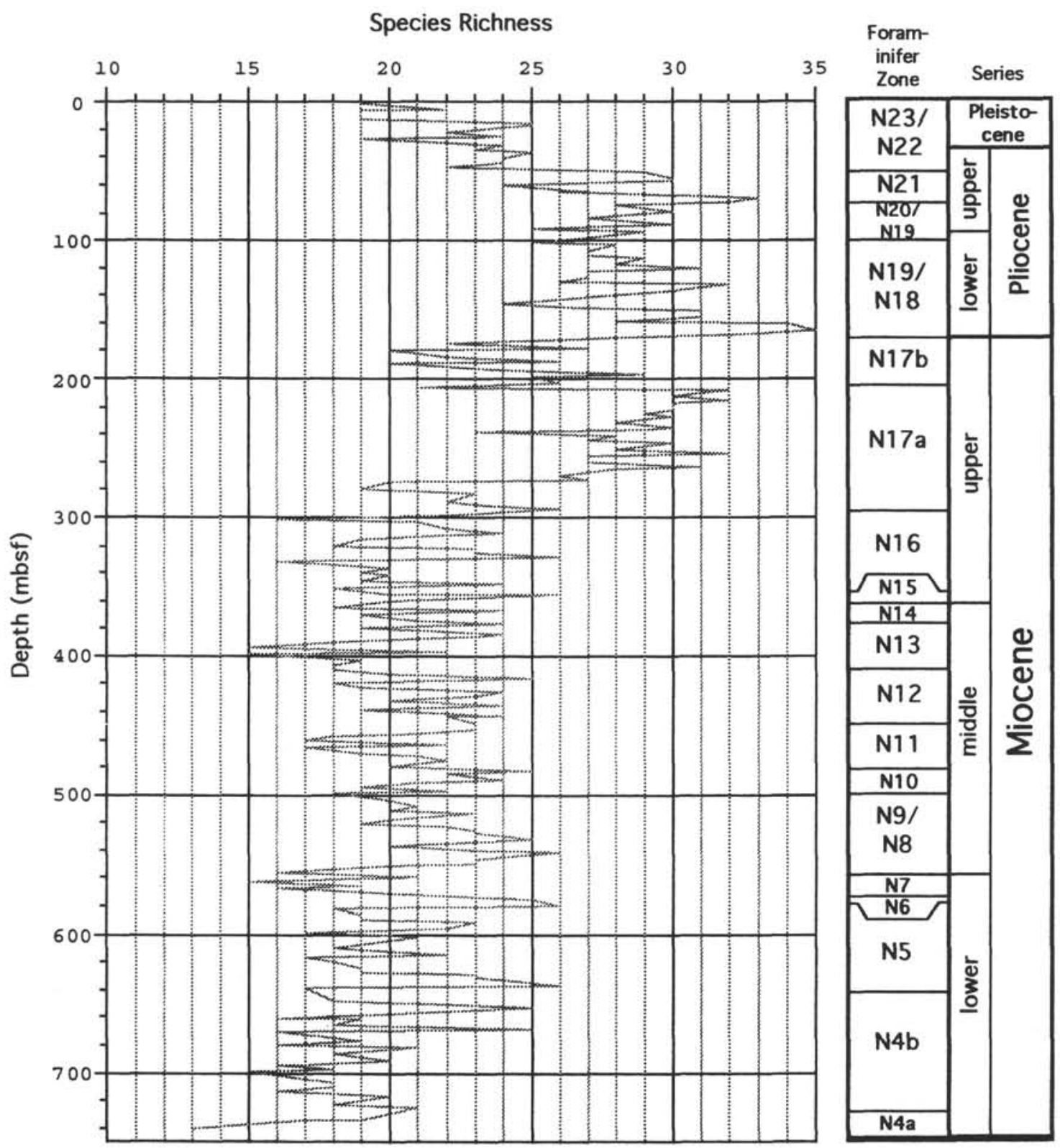

Figure 8. Number of species present (i.e., species richness) in each sample presented in the distribution table (Table 1, in back pocket). Vertical axis represents depth of each sample in Hole 806B.

equatorial Pacific, $P$. mayeri dominates the Zone N4 assemblages (Kennett et al., 1985). All of these taxa have been inferred, on the basis of isotopic evidence, to be surface dwellers (Barrera et al., 1985; Keller, 1985). P. kugleri abruptly disappears at the top of Subzone $\mathrm{N} 4 \mathrm{~b}$ in Hole 806B, and it is replaced in the sediment assemblage primarily by $P$. mayeri and to a lesser extent by $G$. altispira and species of Globigerinoides. Because these are all surface-dwelling taxa, we infer that the latter species filled the niche left vacant by the extinction of $P$. kugleri.

Globigerinita glutinata is common through most of the Neogene section in Hole 806B. Its abundance decreases markedly in Zones N7 through N12 (uppermost lower Miocene to middle Miocene), coincident with increases in the relative abundance of Globigerinoides sacculifer/triloba, perhaps indicating temporary competitive exclusion. Both taxa have been shown to be surface dwellers in the modern ocean (Fairbanks et al., 1982; Ravelo et al., 1990). Globigerinita uvula is a common constituent of the lower Miocene assemblages in
Hole $806 \mathrm{~B}$, but it abruptly decreases in abundance in the basal part of Zone N7 and occurs only sporadically in the middle and upper Miocene. In the lower Miocene of Site 806, G. uvula is quite large compared with late Neogene forms.

Globorotalia praemenardii gives rise to Globorotalia menardii in middle Miocene Zone N12 in the subtropics (Kennett and Srinivasan, 1983; Kennett et al., 1985). G. menardii subsequently moved into the tropics and filled the vacant niche of the $G$. fohsi group (Kennett et al., 1985). On the basis of isotopic evidence, G. fohsi and G. menardii are inferred to have been upper intermediate-water dwellers (Keller, 1985). G. menardii does not appear in Hole 806B until the base of Zone N13. This FO is somewhat higher than the mid Zone N12 FO reported by Srinivasan and Kennett (1981b) in DSDP Site 289. This discrepancy may be partly based on the rather subtle morphological differences between the earliest forms of $G$. menardii and its ancestor. Also noteworthy in the Zone N12/N13 transition in Hole $806 \mathrm{~B}$ is the relatively common occurrence of Globorotalia lenguaensis. These 
Table 4. A comparison of diversity indexes between Site 806 and global values of Wei and Kennett (1986).

\begin{tabular}{|c|c|c|c|c|c|c|c|c|c|c|c|c|c|c|c|}
\hline \multirow{2}{*}{$\begin{array}{l}\text { Age } \\
\text { (Ma) }\end{array}$} & \multirow[b]{2}{*}{ Core, section } & \multicolumn{2}{|c|}{ Depth (mbsf) } & \multirow[b]{2}{*}{ Thickness } & \multirow{2}{*}{$\begin{array}{l}\text { Site } 806 \\
\text { samples }\end{array}$} & \multirow[b]{2}{*}{ FO } & \multirow[b]{2}{*}{ LO } & \multirow[b]{2}{*}{ Richness } & \multirow[b]{2}{*}{ rs } & \multirow[b]{2}{*}{ re } & \multirow[b]{2}{*}{ rd } & \multirow[b]{2}{*}{$r t$} & \multirow{2}{*}{$\begin{array}{c}\text { Wei } \\
\text { Diversity } \\
\end{array}$} & \multirow{2}{*}{$\begin{array}{l}\text { and } \\
\text { rd }\end{array}$} & \multirow{2}{*}{$\begin{array}{c}\text { Kennett } \\
\mathrm{rt}\end{array}$} \\
\hline & & Top & Bottom & & & & & & & & & & & & \\
\hline 1 & $1 \mathrm{H}-2 / 3 \mathrm{H} \cdot \mathrm{CC}$ & 0.00 & 25.50 & 25.50 & 10 & 1 & 3 & 34 & 0.03 & 0.09 & -0.06 & 0.12 & 38.10 & -0.05 & 0.00 \\
\hline 2 & $4 \mathrm{H}-2 / 6 \mathrm{H} \cdot \mathrm{CC}$ & 25.50 & 55.00 & 29.50 & 9 & 4 & 7 & 39 & 0.10 & 0.18 & .0 .08 & 0.28 & 42.60 & -0.12 & 0.26 \\
\hline 3 & $7 \mathrm{H} \cdot 2 / 8 \mathrm{H} \cdot \mathrm{CC}$ & 55.00 & 73.00 & 18.00 & 6 & 1 & 6 & 40 & 0.03 & 0.15 & .0 .13 & 0.18 & 47.00 & -0.06 & 0.34 \\
\hline 4 & $9 \mathrm{H}-2 / 13 \mathrm{H}-5$ & 73.00 & 117.30 & 44.30 & 14 & 5 & 7 & 46 & 0.11 & 0.15 & .0 .04 & 0.26 & 47.60 & -0.06 & 0.19 \\
\hline 5 & $13 \mathrm{H} \cdot \mathrm{CC} / 18 \mathrm{H}-5$ & 117.30 & 164.80 & 47.50 & 15 & 6 & 7 & 46 & 0.13 & 0.15 & -0.02 & 0.28 & 51.30 & .0 .06 & 0.34 \\
\hline 6 & $18 \mathrm{H} \cdot \mathrm{CC} / 23 \mathrm{H}-\mathrm{CC}$ & 164.80 & 215.50 & 50.70 & 16 & 6 & 7 & 47 & 0.13 & 0.15 & .0 .02 & 0.28 & 50.30 & 0.10 & 0.56 \\
\hline 7 & $24 \mathrm{H}-2 / 28 \mathrm{H}-\mathrm{CC}$ & 215.50 & 263.00 & 47.50 & 15 & 2 & 1 & 41 & 0.05 & 0.02 & 0.02 & 0.07 & 45.70 & 0.04 & 0.07 \\
\hline 8 & $29 \mathrm{H} \cdot 2 / 28 \mathrm{H}-\mathrm{CC}$ & 263.00 & 282.00 & 19.00 & 6 & 3 & 0 & 36 & 0.08 & 0.00 & 0.08 & 0.08 & 45.40 & 0.00 & 0.07 \\
\hline 9 & $31 \mathrm{H}-2 / 32 \mathrm{H}-\mathrm{CC}$ & 282.00 & 301.00 & 19.00 & 6 & 4 & 0 & 35 & 0.11 & 0.00 & 0.11 & 0.11 & 42.70 & 0.09 & 0.07 \\
\hline 10 & $32 \mathrm{H}-2 / 34 \mathrm{H}-5$ & 301.00 & 316.80 & 15.80 & 5 & 1 & 0 & 29 & 0.03 & 0.00 & 0.03 & 0.03 & 40.20 & 0.05 & 0.08 \\
\hline 11 & $34 \mathrm{H} \cdot \mathrm{CC} / 39 \mathrm{X} \cdot 5$ & 316.80 & 365.12 & 48.32 & 15 & 5 & 4 & 37 & 0.14 & 0.11 & 0.03 & 0.24 & 39.40 & 0.00 & 0.24 \\
\hline 12 & $39 \mathrm{X}-\mathrm{CC} / 44 \mathrm{X}-5$ & 365.12 & 413.54 & 48.42 & 15 & 2 & 8 & 39 & 0.05 & 0.21 & -0.15 & 0.26 & 40.00 & -0.05 & 0.38 \\
\hline 13 & $44 \mathrm{X}-\mathrm{CC} / 47 \mathrm{X}-\mathrm{CC}$ & 413.54 & 443.03 & 29.49 & 10 & 2 & 2 & 33 & 0.06 & 0.06 & 0.00 & 0.12 & 39.70 & 0.10 & 0.29 \\
\hline 14 & $48 X-2 / 52 X-2$ & 443.03 & 475.09 & 32.06 & 13 & 5 & 5 & 38 & 0.13 & 0.13 & 0.00 & 0.26 & 38.60 & 0.00 & 0.08 \\
\hline 15 & $52 X-5 / 58 \times-2$ & 475.09 & 513.53 & 38.44 & 9 & 4 & 5 & 36 & 0.11 & 0.14 & -0.03 & 0.25 & 39.60 & -0.10 & 0.35 \\
\hline 16 & $55 X-5 / 58 X-2$ & 513.33 & 542.33 & 29.00 & 9 & 3 & 1 & 34 & 0.09 & 0.03 & 0.06 & 0.12 & 41.90 & 0.00 & 0.30 \\
\hline 17 & $58 x \cdot 5 / 60 X-2$ & 542.33 & 561.77 & 19.44 & 6 & 4 & 3 & 34 & 0.12 & 0.09 & 0.03 & 0.21 & 37.90 & 0.16 & 0.28 \\
\hline 18 & $60 x-5 / 61 \times-5$ & 561.77 & 575.77 & 14.00 & 4 & 2 & 2 & 32 & 0.06 & 0.06 & 0.00 & 0.13 & 35.90 & 0.03 & 0.28 \\
\hline 19 & $61 \mathrm{X}-\mathrm{CC}$ & 575.77 & 579.30 & 3.53 & 1 & 1 & 1 & 26 & 0.04 & 0.04 & 0.00 & 0.08 & 32.80 & 0.09 & 0.11 \\
\hline 20 & $62 X-2 / 63 X-C c$ & 579.30 & 598.60 & 19.30 & 7 & 5 & 1 & 28 & 0.18 & 0.04 & 0.14 & 0.21 & 31.70 & 0.00 & 0.12 \\
\hline 21 & $64 X-2 / 66 X-5$ & 598.60 & 624.22 & 25.62 & 7 & 1 & 2 & 27 & 0.04 & 0.07 & -0.04 & 0.11 & 31.40 & 0.00 & 0.22 \\
\hline 22 & $66 \mathrm{X} \cdot \mathrm{CC} / 70 \mathrm{X}-2$ & 624.22 & 657.99 & 33.77 & 10 & 1 & 2 & 30 & 0.03 & 0.07 & -0.03 & 0.10 & 29.60 & 0.14 & 0.19 \\
\hline 23 & $70 x-4 / 75 x-2$ & 657.99 & 706.28 & 48.29 & 16 & 9 & 5 & 34 & 0.26 & 0.15 & 0.12 & 0.41 & 27.90 & 0.22 & 0.20 \\
\hline
\end{tabular}

Notes: $\mathrm{r}_{\mathrm{s}}=$ rate of speciation, $\mathrm{r}_{\mathrm{e}}=$ rate of extinction, $\mathrm{r}_{\mathrm{d}}=$ rate of diversification, and $\mathrm{r}_{\mathrm{t}}=$ rate of turnover. FO $=$ first occurrence and $\mathrm{LO}=$ last occurrence. 


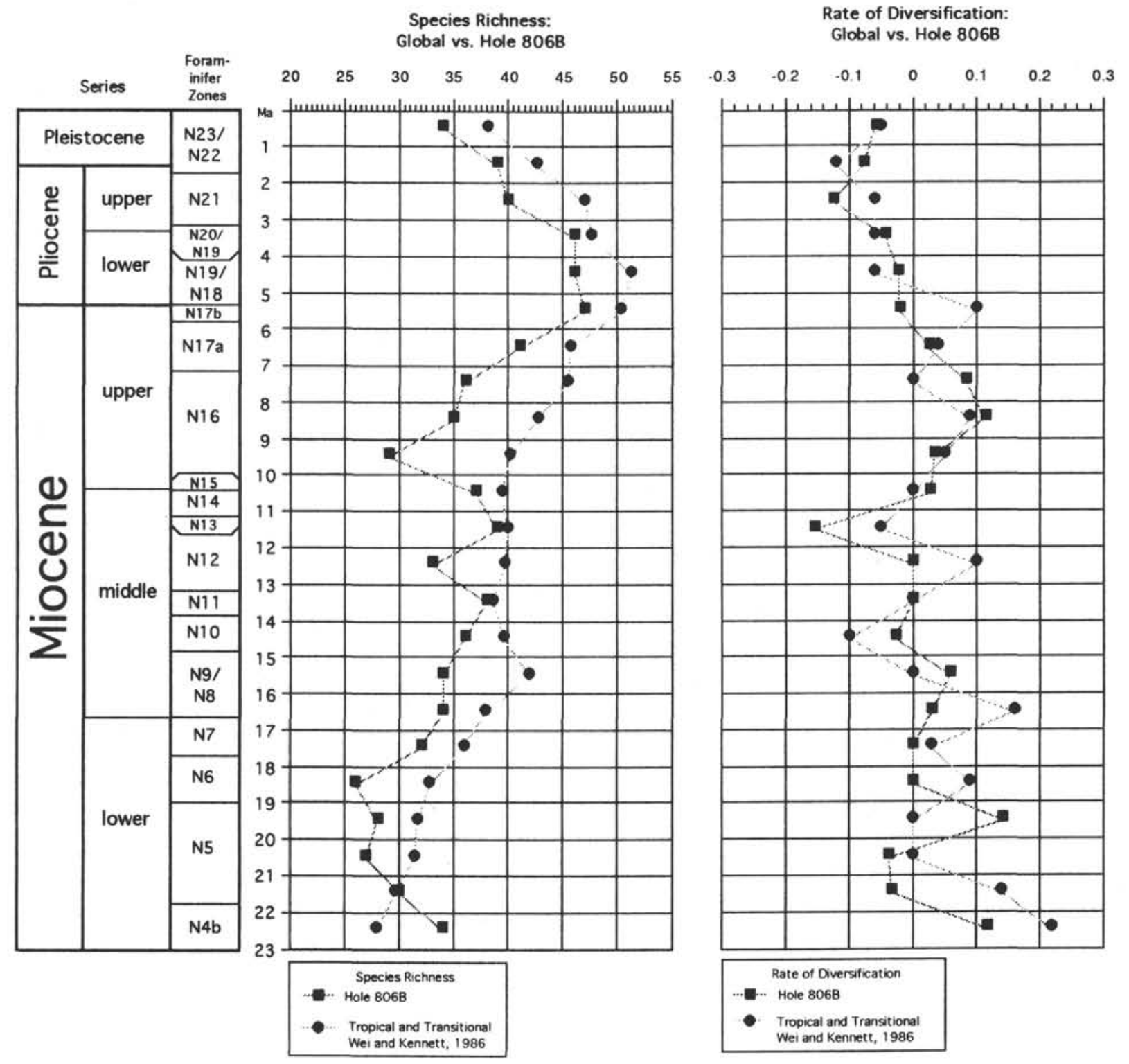

Figure 9. Species richness per million years in Hole 806B and global values. Rates of diversification $\left(r_{d}\right)$ in Hole 806B and global values in the tropical and transition regions. Global values are from Wei and Kennett (1986).

biostratigraphic events are coincident with the closing of the IndoPacific Seaway and the consequent creation of the Equatorial Undercurrent (Kennett et al., 1985). This oceanographic change caused the thermocline to shoal in the equatorial region with a consequent expansion of niche space for upper intermediate-water dwellers. This is reflected by a steady increase in species richness through the late Miocene that is documented by the data from Hole $806 \mathrm{~B}$ and the tropical/transitional data set of Wei and Kennett (1986) (Fig. 9).

Surface-dwelling species dominate the sediment assemblages of the lower and middle Miocene (Fig. 11). Paragloborotalia kugleri, P. mayeri, and Globigerinita glutinata are the most common taxa, along with lesser numbers of Dentoglobigerina altispira and species of Globigerinoides. Intermediate dwellers included Globorotalia praescitula, the $G$. menardii group, and the $G$. fohsi group. These latter taxa, although persistent during their respective ranges, are always rare compared with the surface dwellers. Deep- and intermediate-dwelling taxa, such as species of Catapsydrax, Globoquadrina dehiscens, $G$. venezuelana, and $G$. baroemoenensis, are also persistent components of the sediment assemblages, but they are distinctly less common than the surface dwellers. Globoquadrina dehiscens shows sporadic bursts of abundance in the middle Miocene. At nearby DSDP Site 289, Keller (1985) also shows the dominance of surface dwellers in the lower and middle Miocene based on population counts of the $>150-\mu \mathrm{m}$-size fraction.

With the extinction of Paragloborotalia mayeri at the end of the middle Miocene (Zone N14/N15 boundary) and coincident with the closing of the Indo-Pacific Seaway and the shoaling of the equatorial thermocline, a marked change occurred in the inferred population structure of planktonic foraminiferal assemblages (Fig. 11). A more equitable distribution of surface-, intermediate-, and deep-water dwellers characterizes the sediment assemblages from the upper Miocene through the Pleistocene in Hole 806B. Surface-dweller Dentoglobigerina altispira, intermediate-dweller Globorotalia menardii, and deep-dwelling Streptochilus spp. (Hemleben et al., 1989) all increase markedly in abundance in the lower upper Miocene of Hole 806B (Zone N15). Globoquadrina dehiscens disappears completely in upper Miocene Zone N16 and again in part of Subzone $\mathrm{N} 17 \mathrm{~b}$. The former interval is associated with climatic amelioration, 


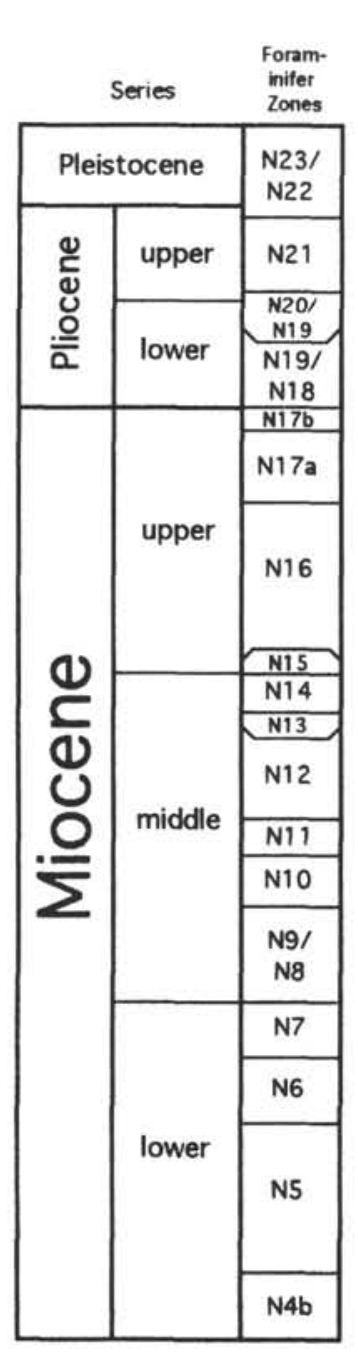

\section{Turnover Rates at Hole 806B}
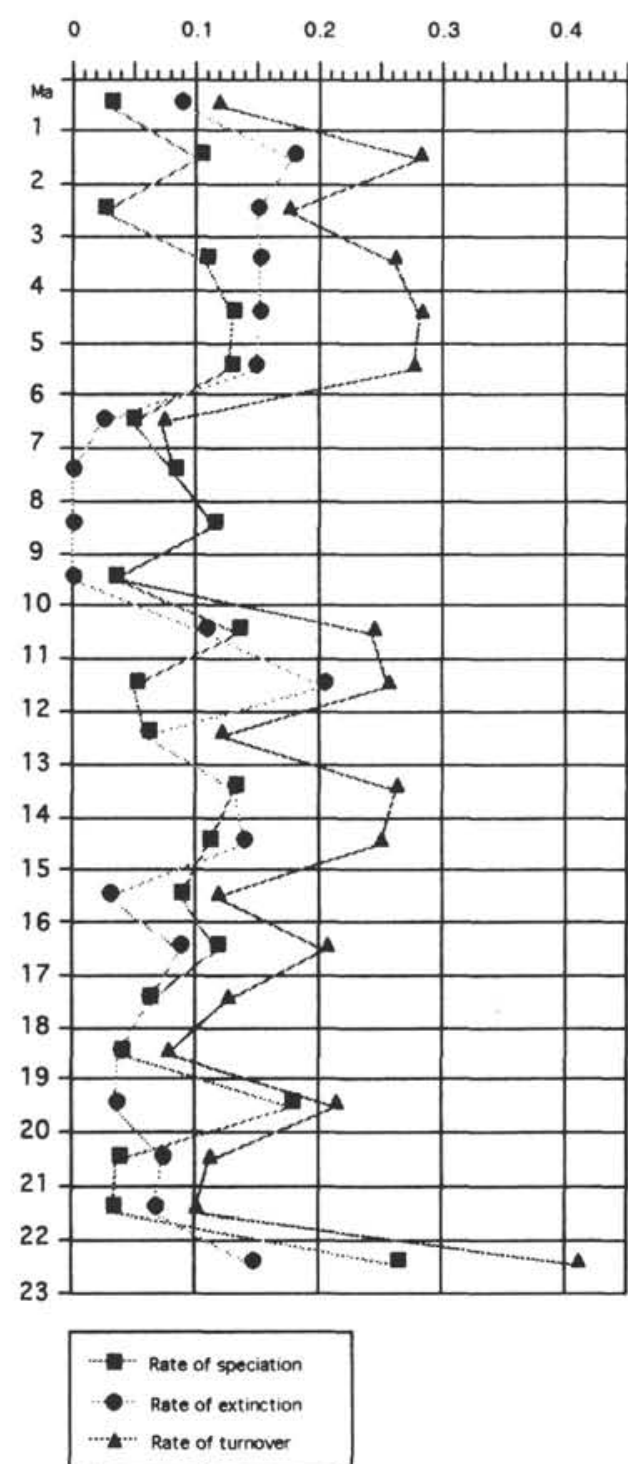

Global Turnover vs. Hole 806B
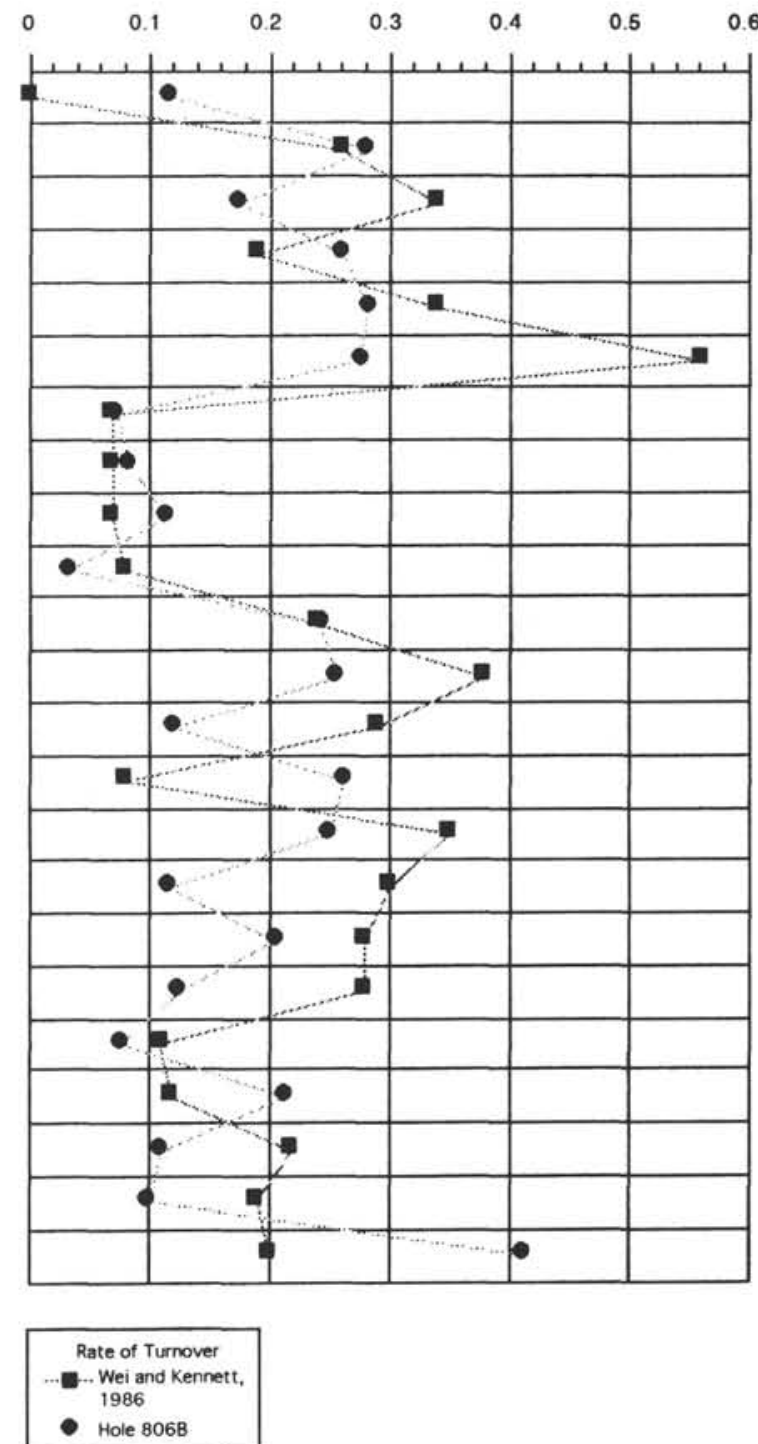

Figure 10. Rates of speciation, extinction, and turnover per million years in Hole 806B. Comparison of turnover rates per million years in Hole 806B and global values of Wei and Kennett (1986).

whereas the latter is associated with major antarctic glaciation (Haq, 1980; Kennett et al., 1985).

Neogloboquadrina acostaensis, an upper intermediate-water dweller (Keller, 1985), shows an acme of abundance in upper Miocene Zone N16 and Subzone N17a. Globigerina bulloides, although rare in absolute abundance, has its most persistent occurrence of the Miocene through this same stratigraphic interval. The co-occurrence of these two taxa with other intermediate- and deep-dwellers through the upper Miocene of Hole $806 \mathrm{~B}$ is coincident with very high sedimentation rates (Fig. 6) and may signal an episode of higher productivity in the western equatorial Pacific (also see Berger et al., this volume).

Globigerina apertura, probably an upper intermediate-water dweller, shows an acme in uppermost Miocene Subzone N17b through lower Pliocene Zone N18/N19. Intermediate-water dwellers, Globorotalia plesiotumida and G. merotumida, are generally rare in the upper Miocene, but G. plesiotumida has a brief acme of abundance in the uppermost part of Subzone N17a. In the Miocene/Pliocene boundary interval, Dentoglobigerina altispira disappears whereas Globoquadrina dehiscens reappears.

In the upper Pliocene (upper part of Zone N19/N20), surfacedweller Globigerinoides ruber and intermediate-dwellers (top of thermocline/chlorophyll maximum; Fairbanks and Wiebe, 1980; Fairbanks et al., 1982; Ravelo et al., 1990) Globorotalia tumida, Pulleniatina obliquiloculata, and Globigerinella aequilateralis all display abrupt increases in relative abundance. These changes are coincident with antarctic glaciation, increased equator to pole temperature gradients, and increased trade wind strength (Keigwin, 1978; Thunell and Belyea, 1982; Wright and Thunell, 1988; Webb and Harwood, 1991; Sikes et al., 1991). The observed increase in abundance of intermediate-water dwellers may signal renewed shoaling of the western equatorial thermocline, or perhaps it signals the establishment of the modern equatorial current system with its distinct eastwest differences in the upper water column structure and productivity.

Globigerinoides ruber tends to be more common in subtropical waters, whereas Globigerinoides sacculifer is more common in tropi- 


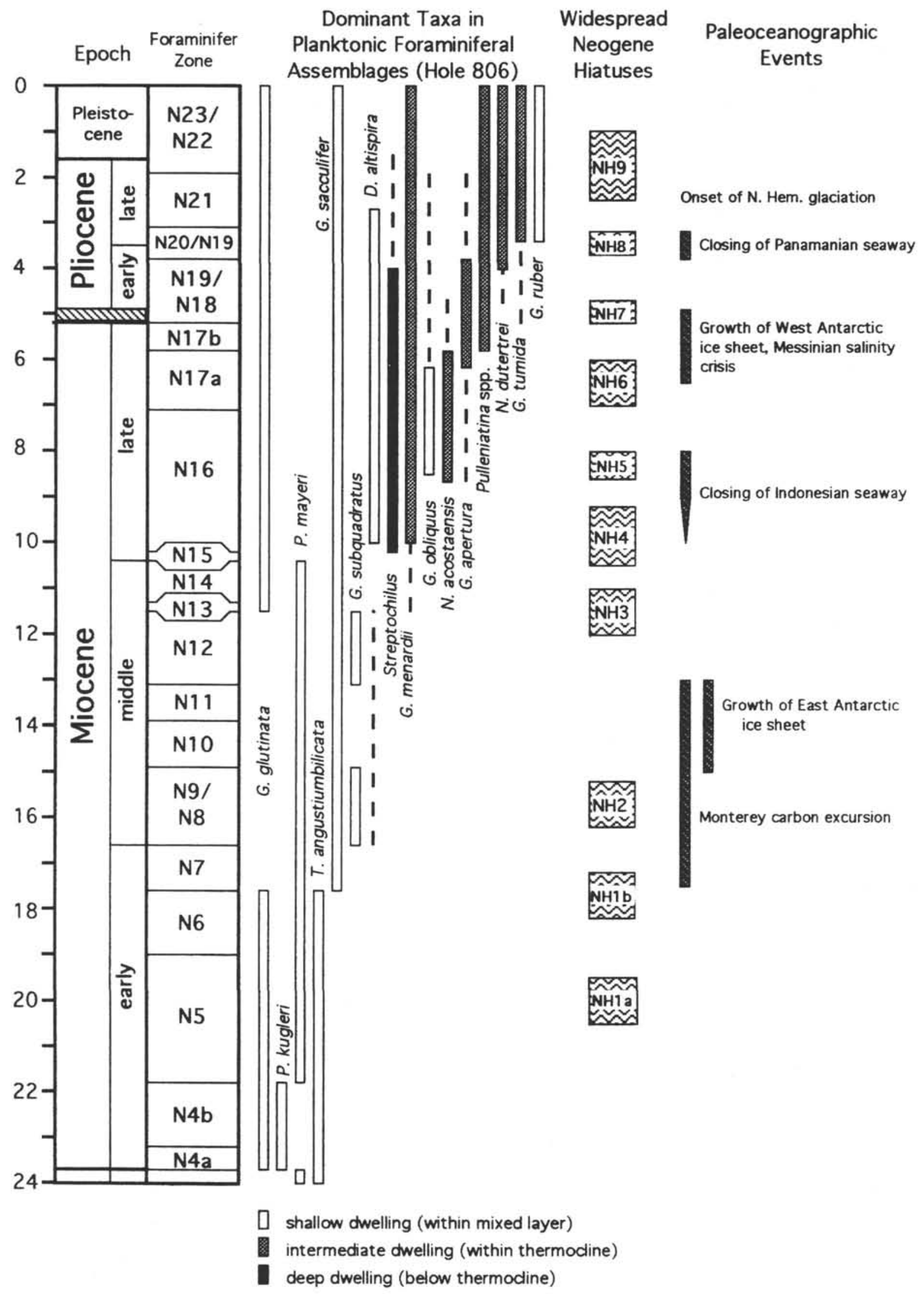

Figure 11. Graphic representation of major changes in planktonic foraminiferal populations throughout Neogene in Site 806. Ages of widespread Neogene hiatuses from Keller and Barron (1987) and Barron (1989). (N.B.: Keller and Barron assign an age of 11.8-12.9 Ma for Hiatus NH3, whereas Barron assigns an age of 11.0-12.0 Ma.) Major paleoceanographic events summarized from Kennett et al. (1985) and Theyer et al. (1989). 
cal waters (Bé and Tolderlund, 1971; Bé and Hutson, 1977). Physical oceanographic gradients of the equatorial surface-water masses steepened with increased circulation vigor. Lower salinity waters in the Equatorial Countercurrent (Levitus, 1982; Delacroix et al., 1987; Pickard and Emery, 1990) may have been confined north and away from Site 806, thereby allowing $G$. ruber to flourish in the saltier near-surface waters of the South Equatorial Current. The shoaling of the equatorial thermocline and the steepening of equatorial surfacewater masses were also closely linked with the closing of the Panama Seaway (Keigwin, 1978; Kennett et al., 1985; Pisias and Prell, 1985).

Globigerina bulloides and Neogloboquadrina dutertrei, two species associated with upwelling in the low latitudes (Duplessy et al., 1981), are both common in the uppermost Pliocene and Pleistocene (Zone N22/N23); the coarseness of the sample interval, however, precludes identifying glacial cycles. G. bulloides, the "cool-water upwelling" indicator species (Duplessy et al., 1981), is noted as "few" or "common" only above Core 130-806B-5H-CC (uppermost Pliocene part of Zone N22/N23). N. dutertrei, the "warm-water upwelling" indicator species, becomes common in the mid-Pliocene (upper Zone $\mathrm{N} 18 / \mathrm{N} 19$ ) and remains common to the top of the section with only occasional brief decreases in abundance. The increase in $N$. dutertrei parallels the gradual demise of Globigerina apertura in the mid-Pliocene. Globorotalia truncatulinoides, a deep-dwelling, midlatitude species (Bé, 1977; Hemleben et al. 1989), occurs sporadically in the uppermost Pliocene and Pleistocene of Hole 806B (Zone $\mathrm{N} 22 / \mathrm{N} 23$ ). It is most common in the lower Pleistocene and is very rare in the upper Pleistocene.

\section{SUMMARY AND CONCLUSIONS}

One hundred and ten species of planktonic foraminifers were identified in 230 samples from the 759-m-thick, virtually complete uppermost Oligocene-Pleistocene pelagic section of Holes 806B and $806 \mathrm{C}$. Lower Miocene Zone N6 and the upper part of mid-Pliocene Zone N19/N20 show evidence of a condensed section and/or hiatus. Foraminiferal preservation ranges from good to moderately poor. Dissolution does not appear to have significantly altered the sediment assemblages, although breakage of foraminiferal tests tends to increase downsection throughout the transition from ooze to chalk. We followed the taxonomy of Kennett and Srinivasan (1983) with only minor exceptions.

We largely follow Blow's (1969) zonal scheme as emended by Srinivasan and Kennett (1981a, 1981b) and Kennett and Srinivasan (1983). We have further emended this low-latitude zonation by subdividing Zone N19 based on a mid-Pliocene coiling change in all species of Pulleniatina dated at 3.8 Ma by Berggren et al. (1985b). The FO of Sphaeroidinella dehiscens is too high in Hole $806 \mathrm{~B}$ to be used as a reliable marker of the Zone N18/N19 boundary. Orbulina also has an anomalously high FO in Hole $806 \mathrm{~B}$, prohibiting the differentiation of lower middle Miocene Zones N8 and N9. The absence of Orbulina in Zones N9 and N10 may be attributed to dissolution at this site. We follow Berggren et al. (1985a, 1985b) and Berggren and Miller (1988) by placing the Oligocene/Miocene boundary at the FO of Paragloborotalia kugleri.

The condensed section of lower Miocene Zone N6 corresponds with major upper lower Miocene unconformities at Sites 803 and 804 on the deep northeastern flank of the Ontong Java Plateau, and with Hiatus NH1b of Keller and Barron (1987). The possible condensed section in mid-Pliocene Zone N19/N20 corresponds with Hiatus NH8 (Keller and Barron, 1987; Barron, 1989). In Hole 806B no biostratigraphic or lithologic evidence is present of other widespread Miocene and Pliocene hiatuses documented elsewhere in the deep sea (Keller and Barron, 1987).

Patterns of species richness and rates of speciation, extinction, and turnover in Hole 806B parallel trends documented by Wei and Ken- nett (1986) for tropical/transitional species of planktonic foraminifers. Temporal changes in these parameters are related to tectonic and climatic events that influence the physical and biological structure of the equatorial upper water column. In Hole 806B, peaks in species richness occur in Subzone N4b (lower Miocene), in Zone N11, in upper Zones N12-N14 (middle Miocene), and in Subzone N17b to Zone N19/N20 (uppermost Miocene to mid-Pliocene). Distinct lows in species richness occur in Zones N5 and N6 (lower Miocene), Zone N12 (middle Miocene), and the lower part of Zone N16 (lower upper Miocene); they culminate in a steady decrease through Zones N21 and N22/N23 (upper Pliocene through Pleistocene). Turnover rates were relatively low in the lower Miocene and rose throughout the mid to upper part of the middle Miocene. Turnover rates were low through much of the upper Miocene, rose dramatically in the uppermost Miocene, and remained high throughout the Pliocene before declining again in the Pleistocene.

Numerous stratigraphic changes occurred in the inferred population structure preserved in the planktonic foraminiferal sediment assemblages throughout the Neogene in Hole 806B. Surface-dwelling taxa (Paragloborotalia kugleri, P. mayeri, and Globigerinita glutinata) dominate the lower and middle Miocene assemblages. The closing of the Indo-Pacific Seaway during the mid to late Miocene resulted in the invigoration of equatorial surface-water masses and shoaling of the thermocline. As a consequence, upper Miocene through Pleistocene assemblages show a more equitable distribution of surface-, intermediate-, and deep-dwelling taxa. For example, intermediatewater dweller Globorotalia menardii becomes common in the upper Miocene and remains common throughout the Pleistocene of Hole 806B. Species of Streptochilus, one of the deepest dwelling genera of modern planktonic foraminifers (Hemleben et al., 1989), are particularly abundant throughout the entire upper Miocene and much of the Pliocene. Successive acmes of abundance are observed in intermediate dwellers Neogloboquadrina acostaensis (upper Miocene), Globigerina apertura (uppermost Miocene-lower Pliocene), and Neogloboquadrina dutertrei (mid-Pliocene-Pleistocene). The upper Pliocene assemblages also show a marked increase in the relative abundances of surface-dweller Globigerinoides ruber, and intermediate-dwellers Globorotalia tumida, Pulleniatina obliquiloculata, and Globigerinella aequilateralis. This latter change is closely related to invigoration of the equatorial surface-water masses in response to the closing of the Panama Seaway, an episode of Antarctic glaciation, and the onset of Northern Hemisphere glaciation.

\section{TAXONOMIC NOTES}

In this study, we have attempted to document as many species as possible so as to establish a robust planktonic foraminiferal biostratigraphy for the thick and virtually complete Neogene sequence of Hole $806 \mathrm{~B}$, and to provide a solid data base of taxon ranges in the western tropical Pacific. We focused much of our effort on species concepts and stratigraphic ranges, with particular attention addressed to the range of morphologic variability and the criteria used to distinguish closely related or morphologically similar taxa. To a great extent, we have followed the taxonomy of Kennett and Srinivasan (1983). Genus assignments, in most cases, are theirs. Exceptions include Praeorbulina sicana, Paragloborotalia kugleri, $P$. mayeri, $P$. nana, and $P$. pseudokugleri. We did not use the subgenera presented by Kennett and Srinivasan (1983). We also used Bolli and Saunders (1985) and original species descriptions from the literature.

We lumped Pulleniatina praecursor under $P$. obliquiloculata and separated Pulleniatina praespectabilis from $P$. spectabilis. Kennett and Srinivasan (1983) regard Globoquadrina conglomerata as synonymous with $G$. baroemoenensis, whereas we treat it as synonymous with Globoquadrina pseudofoliata (cf. Thompson and Sciarrillo, 1978) and consider $G$. baroemoenensis to be a separate species.

In the scanning electron photomicrographs presented on Plates 1 to 10 , we focused primarily on Miocene species. For taxa of some phylogenetically important lineages, we have tried to illustrate the morphologic criteria that we used to distinguish between ancestral and descendant forms, particularly those 
in the sometimes "gray" transition zones of a first occurrence (e.g., Globigerinoides triloba-Praeorbulina sicana, Globigerinita glutinata-Globigerinatella insueta, Globorotalia peripheroronda-G. peripheroacuta-G. praefohsi-G. fohsi, and Globorotalia merotumida-G. plesiotumida-G. tumida). We have also illustrated the rare and tiny temperate-water invaders, as well as some of the more common and characteristic species of the western equatorial Pacific. In many instances, the individual photographs have been arranged "stratigraphically" on the plates to help illustrate size and morphologic changes between phylogenetically related species.

The original reference for each species is included in the notes that follow; however, in most cases, these are not included in our reference list. Complete citations can be found in Kennett and Srinivasan (1983) and Bolli and Saunders (1985)

$$
\text { Beella digitata (Brady) }
$$

Globigerina digitata Brady, 1879, p. 599, pl. 80, figs. 6-10.

Beella digitata (Brady) Kennett and Srinivasan, 1983, p. 232, pl. 58, figs. 2 and 6-8.

Stratigraphic range: Cores 130-806B-5H-5 to $-1 \mathrm{H}-2$ (N22/N23).

$$
\text { Beella praedigitata (Parker) }
$$

Globigerina praedigitata Parker, 1967, p. 151, pl. 19, figs. 5-8.

Beella praedigitata (Parker) Kennett and Srinivasan, 1983, p. 232, pl. 58, figs. $2-5$.

Stratigraphic range: Cores $130-806 \mathrm{~B}-11 \mathrm{H}-\mathrm{CC}$ to $-7 \mathrm{H}-\mathrm{CC}$ (lower N19/N20-mid N21).

\section{Candeina nitida D'Orbigny}

Plate 1, Fig. 8

Candeina nitida d'Orbigny, 1839, p. 107, pl, 2, figs. 27-28; Kennett and Srinivasan, 1983, p. 228 , pl. 57 , figs. $6-8$.

Stratigraphic range: Cores 130-806B-31H-2 to -3H-2 (upper N16-upper N22/N23).

$$
\text { Cassigerinella chipolensis (Cushman and Ponton) }
$$

Cassidulina chipolensis Cushman and Ponton, 1932, p. 98, pl. 15, figs. 2a-c. Cassigerinella chipolensis (Cushman and Ponton) Kennett and Srinivasan, 1983, p. 18, pl. 1, figs. $3-5$.

Stratigraphic range: Cores $130-806 \mathrm{C}-60 \mathrm{X}-\mathrm{CC}$ to $130-806 \mathrm{~B}-42 \mathrm{X}-\mathrm{CC}$ (upper P22-lower N13).

$$
\text { Catapsydrax dissimilis (Cushman and Bermudez) }
$$

Globigerina dissimilis Cushman and Bermudez, 1937, p. 25, pl. 3, figs. 4-6. Catapsydrax dissimilis (Cushman and Bermudez) Kennett and Srinivasan, 1983, p. 22, pl. 2, figs, 1, 3-8.

Stratigraphic range: Cores $130-806 \mathrm{C}-60 \mathrm{X}-\mathrm{CC}$ to $130-806 \mathrm{~B}-61 \mathrm{X}-5$ (upper P22-top of N6).

\section{Catapsydrax parvulus Bolli, Loeblich, and Tappan}

Catapsydrax parvulus Bolli, Loeblich, and Tappan, 1957, p. 36, pl. 7, figs. 10a-c; Kennett and Srinivasan, 1983, p. 26, pl. 2, figs. 7-9.

Stratigraphic range: Cores 130-806B-63X-CC to -55X-5 (upper N5-upper N8/N9).

Catapsydrax unicavus Bolli, Loeblich, and Tappan

Catapsydrax unicavus Bolli, Loeblich, and Tappan, 1957, p. 37, pl. 7, figs. 9a-c; Kennett and Srinivasan, 1983, p. 26, pl. 3, figs. 1-3.

Stratigraphic range: Cores $130-806 \mathrm{C}-60 \mathrm{X}-\mathrm{CC}$ to $130-806 \mathrm{~B}-61 \mathrm{X}-\mathrm{CC}$ (upper P22-N6).

\author{
Dentoglobigerina altispira (Cushman and Jarvis) \\ Plate 9, Fig. 8
}

Globigerina altispira Cushman and Jarvis, 1936, p. 5, pl. 1, figs. 13a-c.

Globoquadrina altispira globosa Bolli, 1957, p. 111, pl. 24, figs. 9a-10c.

Dentoglobigerina altispira altispira (Cushman and Jarvis) Kennett and Srinivasan, 1983, p. 188, pl. 46, figs. 4-6.

Dentoglobigerina altispira globosa (Bolli) Kennett and Srinivasan, 1983, p. 189, pl. 44, fig. 4 ; pl. 46 , figs. $7-9$.

Stratigraphic range: Cores $130-806 \mathrm{~B}-74 \mathrm{X}-3$ to $-8 \mathrm{H}-5$ (lower N4blower N21).

Remarks: This species exhibits a broad spectrum of morphologic variation that has been demarcated into subspecies by some authors (Bolli, 1957; Kennett and Srinivasan, 1983; Bolli and Saunders, 1985). Very few specimens of the Dentoglobigerina altispira globosa morphotype were observed in Hole 806B; therefore, all specimens were assigned to D. altis pira (e.g., see Plate 9, Fig. 12). This taxon is characterized by its well-developed apertural teeth, appressed chambers, deep umbilicus, and moderate to high trochospire.

Similar species: Early forms of $D$. altispira are larger than Globoquadrina cf. G. extans. In addition, D. altispira has a wider umbilicus and better developed apertural teeth.

\section{Globigerina apertura Cushman Plate 1, Fig. 6}

Globigerina apertura Cushman, 1918, p. 57, pl. 12, figs. 8a-c.

Globigerina (Zeaglobigerina) apertura (Cushman) Kennett and Srinivasan, 1983 , p. 44 , pl. 8, figs. $4-6$.

Stratigraphic range: Cores 130-806B-40X-5 to -5H-5 (lower N14-lower N22/N23)

Remarks: Globigerina apertura is particularly common in the uppermost Miocene to mid-Pliocene (Subzone N17b to upper Zone N18/N19).

Similar species: The aperture of Globigerina apertura is very large and often wider than it is high, distinguishing it from both $G$. woodi and $G$. rubescens. G. apertura differs from $G$. decoraperta in having a lower trochospire. The latter two taxa are gradational.

\section{Globigerina bulloides d'Orbigny}

Plate 1, Figs. 13-14

Globigerina bulloides d'Orbigny, 1826, p. 3, pl. 1, figs. 1-4.

Globigerina (Globigerina) bulloides (d'Orbigny) Kennett and Srinivasan, 1983, p. 36, pl. 6, figs. $4-6$.

Stratigraphic range: Cores $130-806 \mathrm{~B}-58 \mathrm{X}-\mathrm{CC}$ to $-1 \mathrm{H}-2$ (lower N8/N9top of $\mathrm{N} 22 / \mathrm{N} 23$ ).

Remarks: Widely accepted as an indicator of high productivity associated with upwelling waters (e.g., Duplessy et al., 1981), this species occurs from the middle Miocene to the Pleistocene; it is much more common, however, in the Pleistocene of Hole 806B. Its morphology is highly variable, but it is identifiable by its highly arched, umbilical aperture. The Miocene forms, in particular, are much smaller than temperate-water forms.

Similar species: No thickened rim occurs around the aperture, and the test is finely perforate and hispid rather than cancellate, which distinguishes this species from Globigerina woodi and G. apertura. G. bulloides is less oblate than $G$. praebulloides.

\section{Globigerina connecta Jenkins} Plate 1, Fig. 15

Globigerina woodi subsp. connecta Jenkins, 1964, p. 72, text figs. 1a-c. Globigerina (Zeaglobigerina) connecta (Jenkins) Kennett and Srinivasan, 1983, p. 44 , pl. 8, figs. 1-3.

Stratigraphic range: Cores 130-806B-76X-CC to $-65 \mathrm{X}-5$ (lower N4blower N5)

Similar species: Globigerina connecta resembles early forms of Globigerinoides triloba, but it lacks the secondary aperture of the latter taxon. See also Globigerina druryi. 
Globigerina decoraperta Takayanagi and Saito Plate 1, Fig. 7

Globigerina druryi Akers decoraperta Takayanagi and Saito, 1962, p. 85, pl. 28 , figs. $10 \mathrm{a}-\mathrm{c}$.

Globigerina decoraperta (Takayanagi and Saito) Kennett and Srinivasan, 1983 , p. 48 , pl. 9 , figs $4-6$.

Stratigraphic range: Cores 130-806B-42X-2 to-7H-2 (upper N13-upper N21). Remarks: Sensu stricto forms of Globigerina decoraperta are rare at this site. Similar species: This species resembles a high trochospire morphotype of Globigerina apertura.

Globigerina druryi Akers

Plate 1, Figs. 10-11

Globigerina druryi Akers, 1955, p. 654, pl. 65, fig. 1.

Globigerina (Zeaglobigerina) druryi (Akers) Kennett and Srinivasan, 1983, p. 46 , pl. 8 , figs. $7-9$.

Stratigraphic range: Cores $130-806 \mathrm{~B}-60 \mathrm{X}-5$ to $-36 \mathrm{X}-2$ (mid N7lower N16).

Similar species: Typical Globigerina nepenthes are not common at this site, and early forms of $G$. nepenthes and late forms of $G$. druryi are gradational in their interval of stratigraphic overlap. Globigerina woodi gives rise to both $G$. druryi and G. connecta in the lower Miocene (Kennett and Srinivasan, 1983), and transitional forms between these three species may be difficult to distinguish (e.g., see Plate 1, Fig. 16). Although G. connecta and G. druryi are both derived from sensu stricto $G$. woodi through the lowering of the arch of the primary aperture, $G$. druryi has a much heavier lip over the aperture and a distinctly more lobate equatorial outline than G. connecta.

\section{Globigerina euapertura Jenkins}

Globigerina euapertura Jenkins, 1960, p. 351, pl. I, figs. $8 \mathrm{a}-\mathrm{c}$; Bolli and Saunders, 1985 , p.180, fig. $13.21 \mathrm{a}-\mathrm{b}$.

Stratigraphic range: Cores $130-806 \mathrm{~B}-78 \mathrm{X}-1$ to $-73 \mathrm{X}-2$ (N4a-mid N4b).

Globigerina gortanii (Borsetti)

Catapsydrax gortanii Borsetti, p. 205, pl. figs. 1a-d.

Globigerina gortanii (Borsetti) Bolli and Saunders, 1985, p. 177, figs. 13.17a$13.17 \mathrm{c}$.

Stratigraphic range: Core 130-806C-60X-CC (upper P22).

Globigerina nepenthes Todd

Plate 1, Fig. 12

Globigerina nepenthes Todd, 1957, p. 301, figs. 7a-b.

Globigerina (Zeaglobigerina) nepenthes (Todd) Kennett and Srinivasan, 1983 , p. 48 , pl. 9 , figs. $1-3$.

Stratigraphic range: Cores $130-806 \mathrm{~B}-40 \mathrm{X}-\mathrm{CC}$ to $-13 \mathrm{H}-2$ (base of N14 upper N18/N19).

Remarks: The usual form of Globigerina nepenthes has a protruding last chamber, an oblate test outline, and a distinct apertural rim. It is rare at this site. What are found instead are very small globigerinid specimens with radially elongate final chambers that are skewed out the regular trochospiral curve and toward the umbilicus. Brönnimann and Resig (1971) called this form G. nepenthoides. We have treated it as an ecophenotype of $G$. nepenthes. Also included under this species concept were globigerinid specimens with "kümmerform" final chambers with apertural rims (cf. Jenkins and Orr, 1972, pl. 10, fig. 9).

Similar species: Specimens of $G$. apertura with a high narrow final chamber can resemble $G$. nepenthes, but the trochospire of $G$. apertura is usually more regular, its final chamber closer to the size of the penultimate chamber, and its aperture is typically much larger than $G$. nepenthes. $G$. nepenthes is gradational with $G$. druryi, but it can be distinquished by its elongated final chamber and more oblate equatorial outline.

\section{Globigerina praebulloides Blow}

Globigerina praebulloides Blow, 1959, p. 180, pl. 8, figs, 47a-c; pl. 9, fig. 48.
Globigerina (Globigerina) praebulloides (Blow) Kennett and Srinivasan, 1983 , p. 38 , pl. 6 , figs. $1-3$.

Stratigraphic range: Cores $130-806 \mathrm{C}-60 \mathrm{X}-\mathrm{CC}$ to $130-806 \mathrm{~B}-60 \mathrm{X}-5$ (upper P22-mid N7)

$$
\text { Globigerina quinqueloba Natland }
$$

Globigerina quinqueloba Natland, 1938, p. 149, pl. 6, figs. 7a-c.

Globigerina (Globigerina) quinqueloba (Natland) Kennett and Srinivasan, 1983 , p. 32 , pl. 5 , figs. $4-6$.

Stratigraphic range: Cores $130-806 \mathrm{~B}-66 \mathrm{X}-2$ to $-1 \mathrm{H}-2$ (lower N5-upper N22/N23).

Remarks: This a temperate-water species that occurs only sporadically and in small numbers at this tropical site.

Similar species: Outside of its optimal range, this species may be smaller than usual and be more easily confused with Turborotalita humilis. Globigerina quinqueloba has only five chambers in the final whorl and a circular outline, whereas $T$. humilis often has six or more chambers and is distinctly more oblate in its equatorial outline. Both species can become encrusted with secondary calcite, making them difficult to tell apart on the basis of texture. In the absence of secondary calcite, $T$. humilis has a smoother test with peripheral pustules, whereas $G$. quinqueloba has a typical globigerine wall texture.

\section{Globigerina rubescens Hofker}

Globigerina rubescens Hofker, 1956, p. 234, pl. 32, fig. 26; pl. 35, figs. 18-21. Globigerina (Zeaglobigerina) rubescens (Hofker) Kennett and Srinivasan, 1983 , p. 50 , pl. 9 , figs. $7-9$.

Stratigraphic range: Cores 130-806B-9H-CC to - $1 \mathrm{H}-2$ (upper N19/N20upper N22/N23).

Remarks: Pink-pigmented specimens are found down to Core 130-806B$2 \mathrm{H}-2$ (upper N22/23). The final chamber of Globigerina rubescens may be smoother than the preceding chambers.

Similar species: Although this species resembles $G$. apertura in its general outline, it is generally more coarsely cancellate with a smaller, more equidimensional aperture. Its chambers are more globose and less embracing than those of $G$. woodi

\section{Globigerina sellii (Borsetti)}

Globoquadrina sellii Borsetti, 1959, p. 209, pl. 1, figs. 3a-d. Globigerina sellii (Borsetti) Bolli and Saunders, 1985, p. 181, fig. 14.11

Stratigraphic range: Cores $130-806 \mathrm{C}-59 \mathrm{X}-\mathrm{CC}$ to $130-806 \mathrm{~B}-73 \mathrm{X}-5$ (upper P22-mid N4b).

\section{Globigerina tripartita Koch}

Globigerina bulloides var. tripartita Koch, 1926, p. 746, p. 737, figs. 21 a-b. Globigerina tripartita (Koch) Bolli and Saunders, 1985, p. 181, fig. 14.13.

Stratigraphic range: Cores $130-806 \mathrm{~B}-78 \mathrm{X}-1$ to $-73 \mathrm{X}-\mathrm{CC}(\mathrm{N} 4 \mathrm{a}-\mathrm{mid} \mathrm{N} 4 \mathrm{~b})$

$$
\begin{gathered}
\text { Globigerina woodi Jenkins } \\
\text { Plate 1, Figs. 17-18 }
\end{gathered}
$$

Globigerina woodi Jenkins, 1960, p. 352, pl. 2, figs. 2a-c.

Globigerina (Zeaglobigerina) woodi (Jenkins) Kennett and Srinivasan, 1983, p. 43 , pl. 7 , figs. $4-6$.

Globigerina (Turborotalita) woodi woodi (Jenkins) Chaproniere, 1988, p. 124, pls. 1 and 2 .

Stratigraphic range: Cores $130-806 \mathrm{~B}-78 \mathrm{X}-\mathrm{CC}$ to $-6 \mathrm{H}-5$ (lower N4abase of $\mathrm{N} 22$ /N23).

Remarks: This is typically a temperate-water species that ranges into the tropics, but it is persistently present at Site 806 .

Similar species: Globigerina woodi can be distinguished from G. apertura by its smaller aperture. Its chambers tend to be more embracing than those of $G$. apertura and that species tends to have a slightly higher trochospire. It is distiniguished from $G$. praebulloides and $G$. bulloides by its cancellate test wall and presence of a distinct apertural rim. Chaproniere (1988) describes great variation in $G$. woodi and illustrates specimens that are very similar to 
G. apertura (his plate 1, fig. 26), G. brazieri (his plate 1, figs. 11 and 17), and G. praebulloides (his plate 2, figs. 23 and 26). We also observed considerable variation in the overall size and shape of the aperture in specimens of $G$. woodi from Site 806

\section{Globigerinatella insueta Cushman and Stainforth} Plate 10, Figs. 4-6

Globigerinatella insueta Cushman and Stainforth, 1945, p. 69, pl. 13, figs 7-9; Kennett and Srinivasan, 1983, p. 228, pl. 56, fig. 2; pl. 57. figs. 4-5.

Stratigraphic range: Cores 130-806B-62X-1 to -54X-5 (base of N6-upper N8/N9).

Remarks: The areal secondary apertures on early forms can be very few ( 1 or 2 ) and difficult to find. They can become blocked with chalk and resemble dimpled pustules. When the areal apertures become more numerous on later forms, they occur in patches on the final chamber.

Similar species: Species of Orbulina are cancellate and more spherical. Early forms of Globigerinatella insueta with few areal apertures are distinguished from Praeorbulina sicana by their microperforate wall in contrast to the distinctly cancellate wall of the latter taxon. $G$. insueta is gradational with Globigerinita glutinata in the early part of its range (e.g., see Plate 10, Fig. 3). These early forms are primarily distinquished by the oversized final chamber. more extensive sutural bullae, presence of areal bullae, and the occasional areal aperture (see Bolli et al., 1957).

\section{Globigerinella aequilateralis (Brady) Plate 1, Figs. 1-2}

Globigerina aequilateralis Brady, 1879, p. 285 (figs. in Brady, 1884, pl. 80 , figs. 18-21).

Globigerinella aequilateralis (Brady) Kennett and Srinivasan, 1983, p. 238, p. 59 , fig. 1 ; pl. 60 , figs. $4-6$.

Stratigraphic range: Cores 130-806B-39X-2 to -1H-2 (base of N15-top of $\mathrm{N} 22 / \mathrm{N} 23$ ).

Remarks: This species is sporadically numerous.

$$
\text { Globigerinella calida (Parker) }
$$

Globigerina calida Parker, 1962, p. 221, pl. 1, figs. 9-13 and 15.

Globigerinella calida (Parker) Kennett and Srinivasan, 1983, p. 240, pl. 60, figs. 7-9.

Stratigraphic range: Cores $130-806 \mathrm{~B}-12 \mathrm{H}-2$ to $-1 \mathrm{H}-2$ (upper N18/N19upper $\mathrm{N} 22 / \mathrm{N} 23$ ).

Remarks: This species is very rare.

Similar species: Globigerinella obesa lacks an apertural lip, and it has more inflated and more embracing chambers than does $G$. calida. $G$. calida differs from Globigerina bulloides in having a less embracing test and a lower arched extraumbilical-tending aperture bordered by a thin lip.

\section{Globigerinella obesa (Bolli)}

Plate 1, Figs. 3-4

Globorotalia obesa Bolli, 1957, p. 119, pl. 29, figs. 2a-3.

Globigerinella obesa (Bolli) Kennett and Srinivasan, 1983, p. 234, pl. 59, figs. 2-5.

Stratigraphic range: Cores 130-806C-59X-CC to 130-806B-6H-5 (upper P22-upper N22/N23).

Remarks: This species is rare. Globigerinella pseudobesa is included under the Globigerinella obesa species concept. Bolli and Saunders (1985) do not show this species ranging above the top of Zone N15.

Similar species: The chambers of Globigerinella obesa are more inflated and more embracing than those of G. calida. G. obesa is distinquished from lower Miocene Tenuitella munda by its larger size and more coarsely perforate wall.

\section{Globigerinita glutinata (Egger) \\ Plate 10, Fig. 2}

Globigerina glutinata Egger, 1893, p. 371, pl. 13, figs. 19-21.

Globigerinita glutinata (Egger) Kennett and Srinivasan, 1983, p. 224, pl. 56, figs. 1 and 3-5.
Stratigraphic range: Cores $130-806 \mathrm{C}-60 \mathrm{X}-\mathrm{CC}$ to $130-806 \mathrm{~B}-1 \mathrm{H}-2$ (upper P22-top of N22/N23).

Remarks: Globigerinita glutinata is the most common and consistently present species in the section. Many specimens in Hole 806B lack bullae but are referred to Globigerinita glutinata. Globigerinita parkerae has a secondary aperture, but it is rare at this site and has been included under the Globigerinita glutinata species concept.

Similar species: See Globigerinatella insueta.

\section{Globigerinita uvula (Ehrenberg)}

Plate 10, Figs. 1 and 7

Pylodexia uvula Ehrenberg, 1861, pl. 2, figs. 24-25.

Globigerinita uvula (Ehrenberg) Kennett and Srinivasan, 1983, p. 224, pl. 56, figs. $6-8$.

Stratigraphic range: Cores $130-806 \mathrm{C}-60 \mathrm{X}-\mathrm{CC}$ to $130-806 \mathrm{~B}-2 \mathrm{H}-\mathrm{CC}$ (upper P22-upper N22/N23).

Remarks: This species is quite rare, except in the lower Miocene where numerous and very large specimens are found.

Similar species: The trochospire of this species is distinctly higher than that of Globigerinita glutinata and no morphological cline between the two morphotypes is observed.

\section{Globigerinoides altiapertura Bolli} Plate 2, Figs. 9-11

Globigerinoides triloba altiapertura Bolli, 1957, p. 113, pl. 25, figs. 7a-c; Kennett and Srinivasan, 1983, p. 54, pl. 10, fig. 1; pl. 11, figs. 4-6.

Stratigraphic range: Cores $130-806 \mathrm{~B}-73 \mathrm{X}-2$ to $-59 \mathrm{X}-2$ (mid N4blower N8/N9).

Remarks: A narrow definition of this species is employed. Any significant departure from roundness of the primary aperture led to the classification of a specimen as Globigerinoides obliquus. In the morphological transition from $G$. altiapertura to $G$. obliquus, lateral oblongation of the aperture seems to precede lateral compression of the chambers. The secondary aperture of $G$. altiapertura is depicted in some illustrations as being nearly as large as the primary aperture (e.g., Bolli, 1957; Poag, 1972), but such specimens are rare at this site, particularly in the early part of its range.

Similar species: This species is distinguished from Globigerinoides obliquus by its more spherical chambers and round primary aperture.

\section{Globigerinoides bollii Blow}

Globigerinoides bollii Blow, 1959, p. 189, pl. 10, figs. 65a-c; Kennett and Srinivasan, 1983, p. 70 , pl. 15 , figs. 4-6.

Stratigraphic range: Cores $130-806 \mathrm{~B}-54 \mathrm{X}-2$ to $-7 \mathrm{H}-2$ (top of N8/N9-upper N21).

Similar species: The primary aperture of Globigerinoides bollii is over a chamber in the final whorl like that of $G$. obliquus rather than a suture. $G$. obliquus, however, has less embracing chambers, its final chamber is more nearly the size of others in the final whorl, and its primary aperture is laterally oblong. G. bollii is more compact than $G$. parawoodi.

\section{Globigerinoides bulloideus Crescenti}

Globigerinoides bulloideus Crescenti, 1966, p. 43, text fig. 8, nos. 3 and 3a, text fig. 9; Kennett and Srinivasan, 1983, p. 60, pl. 12, figs. 7-9.

Stratigraphic range: Cores $130-806 \mathrm{~B}-35 \mathrm{X}-\mathrm{CC}$ to $-25 \mathrm{H}-2$ (lower N16mid N17a).

Remarks: This taxon is very rare and occurs only sporadically in Hole 806B.

$$
\text { Globigerinoides conglobatus (Brady) }
$$

Plate 2, Fig. 8

Globigerina conglobata Brady, 1879, p. 28 b.

Globigerinoides conglobatus (Brady) Kennett and Srinivasan, 1983, p. 58, pl. 12 , figs. 4-6.

Stratigraphic range: Cores $130-806 \mathrm{~B}-19 \mathrm{H}-\mathrm{CC}$ to $-1 \mathrm{H}-2$ (upper N17btop of $\mathrm{N} 22 / \mathrm{N} 23$ ). 
Remarks: This species is never abundant in Hole 806B. It can be encrusted with secondary calcite.

Similar species: See Globigerinoides extremus.

Globigerinoides diminutus Bolli

Plate 2, Fig. 7

Globigerinoides diminutus Bolli, 1957, p. 114, pl. 25, figs. 11a-c; Kennett and Srinivasan, 1983 , p. 74 , pl. 16 , figs. $4-6$.

Stratigraphic range: Cores 130-806B-58X-CC to -54X-5 (lower N8/N9upper N8/N9).

Similar species: Globigerinoides bollii is larger and less spherical. Its primary aperture is over a chamber, whereas that of $G$. diminutus is over a suture. G. diminutus is also smaller than $G$. subquadratus, and it has a distinctly more compact test.

\section{Globigerinoides extremus Bolli}

Plate 2, Fig. 3

Globigerinoides obliquus extremus Bolli and Bermudez, 1965, p. 139, pl. 1, figs. 10-12; Bolli and Saunders, 1985, p. 194, fig. 20.11.

Globigerinoides extremus (Bolli) Kennett and Srinivasan, 1983, p. 58, p. 12, figs. 1-3.

Stratigraphic range: Cores 130-806B-31H-5 to -6H-5 (upper N16-base of N22/N23).

Similar species: To be classified as Globigerinoides extremus, rather than as $G$. obliquus, specimens have a laterally compressed to nearly flat final chamber. The lateral compression of the chambers of specimens of $G$. conglobatus is accompanied by rounding of the edges of each chamber, giving the entire test a more spherical appearance.

\section{Globigerinoides fistulosus (Schubert) Plate 2, Fig. 4}

Globigerina fistulosa Schubert, 1910, p. 323, text fig. 1.

Globigerinoides fistulosus (Schubert) Kennett and Srinivasan, 1983, p. 68, pl. 14, figs. 7-9.

Stratigraphic range: Cores $130-806 \mathrm{~B}-8 \mathrm{H}-5$ to $-5 \mathrm{H}-2$ (lower N21-lower $\mathrm{N} 22 / \mathrm{N} 23$ ). This range refers to the sensu stricto morphotype.

Remarks: The LO of Globigerinoides fistulosus approximates the Pliocene/Pleistocene boundary at 1.6 Ma (Berggren et al., 1985b). Specimens of Globigerinoides sacculifer preceding the FO of Globigerinoides fistulosus s.s. begin to show signs of finger-like projections on and flattening of the final chamber. These specimens have been designated G. fistulosus s.l., and their presence is indicated on the range chart by queries.

\section{Globigerinoides obliquus Bolli}

Plate 2, Figs. 1-2

Globigerinoides obliqua Bolli, 1957, p. 113, pl. 25, figs. 10a-c.

Globigerinoides obliquus (Bolli) Kennett and Srinivasan, 1983, p. 56, pl. 11 , figs. 7-9.

Stratigraphic range: Cores $130-806 \mathrm{~B}-70 \mathrm{X}-2$ to $-5 \mathrm{H}-5$ (upper N4b-lower N22/N23)

Remarks: A broad interpretation of this species concept is employed.

Similar species: Globigerinoides obliquus is gradational with $G$. extremus, but it can be distinquished by its more inflated final chamber. Early forms of $G$. obliquus differ primarily from $G$. altiapertura and $G$. parawoodi in the shape of the primary aperture, G. obliquus being characterized by an asymmetric aperture (i.e., wider than high). See Globigerinoides altiapertura.

\section{Globigerinoides parawoodi Keller}

Globigerinoides parawoodi Keller, 1981a, p. 304, pl. 4, figs. 1-11; Kennett and Srinivasan, 1983 , p. 73 , pl. 15, figs. 1-3.

Stratigraphic range: Cores $130-806 \mathrm{~B}-71 \mathrm{X}-3$ to $-60 \mathrm{X}-2$ (upper N4b-upper N7).

Remarks: This is another possible ecophenotype rather than a species that by acquiring a secondary aperture, is recognized as a "species" of Globigeri noides.
Similar species: This species looks like a Globigerina woodi with a single small secondary aperture opposite the primary aperture. Globigerinoides parawoodi is distinguished from early forms of $G$. obliquus by possessing a more circular primary aperture.

\section{Globigerinoides primordius Blow and Banner}

Plate 2, Fig. 13

Globigerinoides primordius Blow and Banner, 1962, p. 15, pl. ix, figs. Dd-Ff; Kennett and Srinivasan, 1983, p. 54, pl. 11, figs. 1-3.

Stratigraphic range: Cores $130-806 \mathrm{~B}-76 \mathrm{X}-\mathrm{CC}$ to $-64 \mathrm{X}-2$ (lower N4bupper N5).

Similar species: The surface texture of Globigerinoides primordius resembles its ancestor Globigerina praebulloides in being smoother and less coarsely cancellate than Globigerinoides triloba. G. primordius also differs from early forms of $G$. triloba in having higher arched apertures, although not as high as $G$. altiapertura.

\section{Globigerinoides ruber (d'Orbigny)}

Globigerina rubra d'Orbigny, 1839 , p. 82, pl. 4, figs. 12-14.

Globigerinoides ruber (d'Orbigny) Kennett and Srinivasan, 1983, p. 10, fig. 6 ; pl. 17, figs. 1-3.

Stratigraphic range: Cores $130-806 \mathrm{~B}-32 \mathrm{H}-\mathrm{CC}$ to $-1 \mathrm{H}-2$ (upper N16N22/N23)

Remarks: Most abundant in the uppermost Pliocene and Pleistocene (Cores 130-806B-6H-CC to $1 \mathrm{H}-2$ ) in this hole, Globigerinoides ruber is very rare and sporadic below Core 130-806B-10H-2 (mid-Pliocene). The final chamber is often the smallest in the final whorl and may be asymmetric in umbilical view. Rare high-spired forms were also noted.

Similar species: The LO of G. subquadratus in Core 130-806B$40 \mathrm{X}-\mathrm{CC}$ creates a large stratigraphic gap between these homeomorphs. See $G$. bollii.

$$
\text { Globigerinoides sacculifer (Brady) }
$$

Plate 2, Fig. 16

Globigerina sacculifera Brady, 1877, p. 164, pl. 9, figs. 7-10.

Globigerinoides sacculifer (Brady) Kennett and Srinivasan, 1983, p. 66, pl. 14. figs. $4-6$.

Stratigraphic range: Cores $130-806 \mathrm{~B}-71 \mathrm{X}-3$ to $-1 \mathrm{H}-2$ (upper N4b-top of N22/N23).

Remarks: Early forms of Globigerinoides sacculifer differ from $G$. triloba in being less cancellate and in having a more lobate test. However, lower and middle Miocene specimens of both taxa are gradational, making differentiation highly subjective. In this study, a broader species concept is applied to G. sacculifer. Specimens possessing the "saclike" final chamber first appear in Core 130-806B-36 H-5 (upper Miocene) and thereafter become increasing abundant. After its initial occurrence, the saclike final chamber becomes generally larger and increasingly irregular in shape, culminating in G. fistulosus in the mid-Pliocene. Throughout its range, G. sacculifer is gradational with $G$. triloba, $G$. quadrilobatus, and $G$. immaturus in most samples. Therefore, most of these morphological forms are included under the G. sacculifer species concept in this study.

Similar species: Dissolved specimens of Sphaeroidinella dehiscens and Sphaeroidinellopsis seminulina can resemble this species if their cortex has been removed (or if it has not yet developed, as in the case of juvenile specimens).

\section{Globigerinoides sicana/bisphericus}

Globigerinoides bisphericus Todd, 1954, p. 681, pl. 1, figs. la-c and 4.

Stratigraphic range: Cores $130-806 \mathrm{~B}-60 \mathrm{X}-5$ to $-51 \mathrm{X}-\mathrm{CC}$ (lower N7base of N11).

Remarks: This taxon represents a transitional form between Globigerinoides triloba and Praeorbulina sicana. We have applied the species concepts of these taxa somewhat differently than Jenkins et al. (1981) because of the relatively poor preservation and few specimens recovered in each sample.

Similar species: $G$. sicana/bisphericus differs from $G$. triloba in having a larger, more embracing final chamber, and it differs from $P$. sicana in having only two low apertures visible along the base of the final chamber. 
Globigerinoides subquadratus Brönnimann

Plate 2, Fig. 12

Globigerinoides subquadratus Brönnimann, 1954, p. 680, pl. 1, figs. 8a-c; Kennett and Srinivasan, 1983, p. 74, pl. 16, figs. 1-3.

Stratigraphic range: Cores $130-806 \mathrm{~B}-72 \mathrm{X}-2$ to $-40 \mathrm{X}-\mathrm{CC}$ (mid N4b-base of N14).

Remarks: This is a homeomorph of Globigerinoides ruber, clearly separated from it in Hole 806B. It has a distinct rim around the primary aperture, a feature that is less robust in $G$. ruber.

\section{Globigerinoides tenellus Parker}

Globigerinoides tenella Parker, 1958, p. 280, pl. 6, figs. 7-11.

Globigerinoides tenullus (Parker) Kennett and Srinivasan, 1983, p. 80, pl. 17, figs. 7-9.

Stratigraphic range: Cores 130-806B-5H-2 to $-1 \mathrm{H}-2$ (N22/N23).

Remarks: Rare. When Globigerina rubescens develops a secondary aperture, it becomes Globigerinoides tenellus.

\section{Globigerinoides triloba (Reuss)}

Plate 2, Figs. 14-15

Globigerina triloba Reuss, 1850 , p. 374 , pl. 447 , figs. 11 a-c.

Globigerinoides triloba (Reuss) Kennett and Srinivasan, 1983, p. 62, p. 10 , fig. 4 ; pl. 13, figs. 1-3.

Globigerinoides trilobus (Reuss) Bolli and Saunders, 1985, p. 196, fig. 20.15.

Stratigraphic range: Cores $130-806 \mathrm{~B}-76 \mathrm{X}-2$ to $-3 \mathrm{H}-2$ (lower N4b-mid N22/N23).

Similar species: Typical specimens are coarsely cancellate, and the test is more compact than early forms of Globigerinoides sacculifer. Also see Globigerinoides sicana/bisphericus.

\section{Globoquadrina baroemoenensis (LeRoy)} Plate 9, Figs. 5-7

Globigerina baroemoenensis LeRoy, 1939, p. 263, pl. 6, figs. 1-2.

Globoquadrina baroemoenensis (LeRoy) Kennett and Srinivasan, 1983, p. 186, pl. 6, figs. 1-3.

Stratigraphic range: Cores $130-806 \mathrm{C}-60 \mathrm{X}-\mathrm{CC}$ to $130-806 \mathrm{~B}-18 \mathrm{H}-2$ (upper P22-lower N18/N19).

Remarks: This is a medium to large species. There are consistently four chambers in the final whorl. The umbilicus is open and the umbilical faces of the chambers may be somewhat flattened, particularly the final chamber, and perforate. All of the chambers in the final whorl tend to be subround and somewhat laterally compressed. A small umbilical tooth is usually present on the final chamber.

Similar species: Kennett and Srinivasan (1983) considered Globoquadrina baroemoenensis to be synonymous with $G$. conglomerata. The former species, however, can be distinguished by the umbilical flattening of its chambers. $G$. conglomerata may have only three and a half chambers in the final whorl, whereas $G$. baroemoenensis always has four. Globoquadrina venezuelana has a more closed umbilicus and more embracing chambers. Globoquadrina dehiscens shows distinct flattening of the apertural face, which is imperforate, and the chambers are more embracing than in G. baroemoenensis.

\section{Globoquadrina binaiensis (Koch)}

Plate 9, Fig. 13

Globigerina binaiensis Koch, 1935, p. 558.

Globoquadrina binaiensis (Koch) Kennett and Srinivasan, 1983, p. 187, pl. 44 , figs. 1 and 3 ; pl. 45 , figs. $1-3$.

Stratigraphic range: Cores $130-806 \mathrm{~B}-71 \mathrm{X}-3$ to $-63 \mathrm{X}-2$ (upper N4b-upper N5).

Similar species: Sensu stricto forms of Globoquadrina binaiensis are easily recognized by their large final chamber, flattened apertural face, and three chambers in the final whorl. However, several samples contain specimens gradational with $G$. dehiscens. In such cases, distinction is made on the number of chambers in the final whorl, three as compared with four in the latter. G. binaiensis differs from Globigerina sellii in having an angular edge on the final chamber and a distinctly flatter apertural face (cf. with illustrations in Leckie et al., this volume).

\section{Globoquadrina conglomerata (Schwager)} Plate 9, Fig. 1

Globoquadrina conglomerata Schwager, 1866, p. 255, pl. 7, fig. 113; Parker, 1962 , p. 240 , pl. 6 , figs. 11-18; Parker, 1967, p. 165 , pl. 27, fig. 4. Globoquadrina pseudofoliata Parker, 1967, p. 170, pl. 27, figs. 1-3.

Stratigraphic range: Cores $130-806 \mathrm{~B}-19 \mathrm{H}-5$ to $-1 \mathrm{H}-2$ (uppermost N17btop of $\mathrm{N} 22 / \mathrm{N} 23$ ).

Remarks: Globoquadrina conglomerata is a large to very large species with a large, open umbilical aperture surmounted by a triangular tooth on the final chamber. The test is distinctly cancellate. Seen in edge view, the chambers can be spherical or slightly laterally compressed. The variation in chamber shape shows no monotonic stratigraphic trend. There are three and half to four chambers in the final whorl. Thompson and Sciarrillo (1978) consider $G$. conglomerata and $G$. pseudofoliata to be descendants of $G$. venezuelana. Kennett and Srinivasan (1983) think that $G$. venezuelana and G. baroemoenensis are unrelated and that the latter species is synonomous with $G$. conglomerata. In Hole 806B, a morphological cline exists among all four species. $G$. conglomerata and $G$. pseudofoliata are sufficiently similar morphologically and mixed stratigraphically to be considered synonymous.

Similar species: Evolution from $G$. venezuelana involved inflation of the chambers, a widening of the umbilicus, and broadening of the base of the umbilical tooth (Parker, 1967; Thompson and Sciarrillo, 1978). Some specimens retain the tendencies of $G$. venezuelana toward axially elongate chambers and an irregular final chamber, but they always have a more open umbilicus. The ventral sides of chambers of $G$. conglomerata tend to be more inflated than those of $G$. baroemoenensis.

Globoquadrina dehiscens (Chapman, Parr and Collins) Plate 9, Figs. 14-16

Globorotalia dehiscens Chapman, Parr and Collins, 1934, p. 569, pl. 11, figs. $36 \mathrm{a}-\mathrm{c}$.

Globoquadrina dehiscens (Chapman, Parr and Collins) Kennett and Srinivasan, 1983, p. 184, pl. 44, fig. 2 ; pl. 45, figs. 7-9.

Stratigraphic range: Cores $130-806 \mathrm{~B}-77 \mathrm{X}-\mathrm{CC}$ to $-18 \mathrm{H}-\mathrm{CC}$ (base of N4b-basal N18/N19).

Remarks: The LO of this species is above the FO of Globorotalia tumida in Hole 806B. The same stratigraphic relationship is noted by Srinivasan and Kennett (1981a, 1981b) in DSDP Hole 289B. The FO of Globoquadrina dehiscens marks the top of Subzone N4a/base of Subzone N4b (Kennett and Srinivasan, 1983). G. dehiscens is a fairly persistent taxon throughout the Miocene of Hole 806B, but it disappears in Zone N16 and part of Subzone $\mathrm{N} 17 \mathrm{~b}$ (upper Miocene) and has sporadic bursts of high abundance in the middle Miocene.

Similar species: The final chamber of $G$. dehiscens is distinctly flattened and mostly imperforate, and its chambers are more angular and embracing than G. baroemoenensis.

\section{Globoquadrina cf. G. extans (Jenkins)} Plate 9, Figs. 9-11

Globorotalia extans Jenkins, 1960, p. 360, pl. 4, figs. 4a-c and 5a-c.

Stratigraphic range: Cores $130-806 \mathrm{~B}-77 \mathrm{X}-\mathrm{CC}$ to $-68 \mathrm{X}-1$ (base of N4blower N5).

Remarks: This persistent basal Miocene taxon is characterized by four and a half to five and a half chambers in the final whorl, an off-center umbilical aperture bordered by a thin almost toothlike lip, and a distinctly cancellate wall. It differs from Jenkins's (1960) type specimens in having a low to moderate spire as opposed to being nearly flat on the dorsal side.

Similar species: Globoquadrina cf. G. extans differs from Dentoglobig erina altispira globosa, the ancestor of $D$. altispira altispira (Kennett and Srinivasan, 1983), in being smaller, in lacking the well-developed apertural toothlike projections, and in having an aperture located squarely in the center of the ventral side of the test. Further work may prove that $G$. cf. G. extans is in fact closely related to the $D$, altispira group. 


\section{Globoquadrina venezuelana (Hedberg)}

Globigerina venezuelana Hedberg, 1937, p. 681, pl. 92, fig. 72 b.

Globoquadrina venezuelana (Hedberg) Kennett and Srinivasan, 1983, p. 180 , pl. 44, figs. 5-7.

Stratigraphic range: Cores $130-806 \mathrm{C}-60 \mathrm{X}-\mathrm{CC}$ to $130-806 \mathrm{~B}-11 \mathrm{H}-5$ (upper P22-lower N19/N20).

Remarks: The shape of the chambers in the final whorl of this species can vary markedly from specimen to specimen. There are, however, consistently four in the final whorl, with the last often irregular in shape and bent toward the umbilicus. Fifth chambers, when present, are very small and bulla-like.

Similar species: Parker (1967, p. 166) describes a gradual development of Globoquadrina conglomerata from $G$. venezuelana from the upper Pliocene into the basal Pleistocene. The former species has a more open umbilicus and more inflated chambers.

\section{Globorotalia anfracta Parker}

Globorotalia anfracta Parker, 1967, p. 175, pl. 28, figs. 3-8.

Globorotalia (Tenuitella) anfracta (Parker) Kennett and Srinivasan, 1983, p. 164 , pl. 40 , figs. $7-9$.

Tenuitella fleisheri (Parker) Qianyu, 1987, p. 309, pl. 4, figs. 1-7.

Stratigraphic range: Cores 130-806B-10H-2 to $-1 \mathrm{H}-2$ (mid N19/N20top of $\mathrm{N} 22 / \mathrm{N} 23$ ).

Remarks: The glassy, microperforate test of specimens found in Hole $806 \mathrm{~B}$ suggest a closer relationship to Tenuitellinata angustiumbilicata and Tenuitella clemenciae than to other globorotaliids. Because the species is rare and few specimens are available for comparison, we have left the species within Globorotalia. For a detailed discussion of the tenuitellid plexus, see Qianyu (1987).

\section{Globorotalia archeomenardii Bolli} Plate 5, Figs. 16-20

Globorotalia archeomenardii Bolli, 1957, p. 119, pl. 28, figs. 11a-c; Bolli and Saunders, 1985 , p. 220 , figs. $32.6 a-c$.

Globorotalia (Menardella) archeomenardii (Bolli) Kennett and Srinivasan, 1983, p. 122 , pl. 28 , figs. $3-5$.

Stratigraphic range: Cores 130-806B-56X-2 to -52X-CC (upper N8/N9upper N10).

Similar species: Globorotalia archeomenardii has a distinctly more biconvex test and angular peripheral margin than its ancestor Globorotalia praescitula (Kennett and Srinivasan, 1983), and it is more convex on the spiral side than its descendant $G$. praemenardii. In addition, $G$. archeomenardii also has more chambers than $G$. praescitula (five to five and a half, compared with four to four and a half), and it lacks the raised dorsal sutures and well-developed peripheral keel characteristic of $G$. praemenardii.

\section{Globorotalia bermudezi Rögl and Bolli}

Globorotalia bermudezi Rögl and Bolli, 1973, p. 567, pl. 6, figs. 16-20, pl. 16, figs. 1-3, text figs. 6a-c; Kennett and Srinvasan, 1983, p. 140, pl. 31 , fig. 2, pl. 33, figs. $1-3$.

Stratigraphic range: Cores $130-806 \mathrm{~B}-5 \mathrm{H}-2$ to $-4 \mathrm{H}-5$ (lower N22/N23),

\section{Globorotalia bimageae Blow} Plate 4, Figs. 19-22

Globorotalia birageae Blow, 1959, p. 210, pl. 17, figs. 108a-c.

Stratigraphic range: Cores 130-806B-71X-CC to -51X-2 (upper N4blower N11).

Similar species: Globorotalia birnageae is distinguished from G. peripheroronda by its generally smaller size and nearly circular equatorial outline.

Globorotalia challengeri Srinivasan and Kennett Plate 4, Figs. 1-5

Globorotalia challengeri Srinivasan and Kennett, 1981b, pp. 499-533, pl. 1. Globorotalia (Hirsutella) challengeri Kennett and Srinivasan, 1983, p. 142, pl. 33, figs. 7-9.
Stratigraphic range: Cores $130-806 \mathrm{~B}-41 \mathrm{X}-5$ to $-37 \mathrm{X}-\mathrm{CC}$ (upper N13lower N16)

Remarks: A temperate zone species found in low numbers at this tropical site.

Similar species: Globorotalia challengeri looks like a tiny, delicate Paragloborotalia mayeri. In addition to being distinctly smaller, G. challengeri has a more circular equatorial profile and a lower arched aperture than $P$. mayeri. It differs from early forms of Neogloboquadrina acostaensis in lacking the distinctive apertural flap or kümmerform-like final chamber commonly developed on $N$. acostaensis, and in having a final chamber that is distinctly ovate in equatorial view as compared with the spherical chambers developed in species of Neogloboquadrina. In addition, the wall of $G$. challengeri is coarsely perforate on the early whorls and on the earliest chambers of the final whorl, and then becomes more finely perforate with each successive chamber. $N$. acostaensis, on the other hand, is more or less uniformly perforate throughout its ontogeny.

\section{Globorotalia cibaoensis Bermudez} Plate 6, Figs. 12-14 and 19

Globorotalia cibaoensis Bermudez, 1949, p. 285, pl. 22, figs. 21-23.

Globorotalia (Hirsutella) cibaoensis (Bermudez) Kennett and Srinivasan, 1983 , p. 136, pl. 32, figs. 1-3.

Stratigraphic range: Cores $130-806 \mathrm{~B}-29 \mathrm{H}-5$ to $-15 \mathrm{H}-\mathrm{CC}$ (top of N16mid N18/N19).

Similar species: Globorotalia cibaoensis is a variable taxon, particularly in its peripheral outline. It ranges from biconvex to nearly planoconvex, with the spiral side being nearly flat and in extreme cases slightly concave. The planoconvex forms tend to have five chambers, rather than four to four and a half, and resemble $G$. crassula in possessing an angular, keel-like final chamber. $G$. juanai has more inflated chambers on the umbilical side and a more rounded periphery. G. margaritae differs from G. cibaoensis in being concavo-convex (i.e., convex ventral side) and in possessing a thin keel. Also see Globorotalia scitula.

\section{Globorotalia crassaformis (Galloway and Wissler)}

Globigerina crassaformis Galloway and Wissler, 1927, p. 41, pl. 7, fig. 12.

Globorotalia (Truncorotalia) crassaformis (Galloway and Wissler) Kennett and Srinivasan, 1983, p. 146, pl. 34, figs. 6-8.

Globorotalia crassaformis crassaformis (Galloway and Wissler) Bolli and Saunders, 1985 , p. 230 , figs. $36.6-7$.

Stratigraphic range: Cores $130-806 \mathrm{~B}-10 \mathrm{H}-\mathrm{CC}$ to $-1 \mathrm{H}-5$ (upper N19/N20-upper N22/N23).

Similar species: Globorotalia crassiformis has fewer chambers and a more lobate equatorial outline than $G$. tosaensis.

\section{Globorotalia crassula Cushman and Stewart}

Globorotalia crassula Cushman and Stewart, 1930, p. 77, pl. 7, figs. 1a-c. Globorotalia (Truncorotalia) crassula (Cushman and Stewart) Kennett and Srinivasan, 1983, p. 144, pl. 34, figs. 3-5.

Stratigraphic range: Core 130-806B-19H-5 (top of N17b).

Remarks: This taxon is very rare in Hole $806 \mathrm{~B}$ and is gradational with Globorotalia cibaoensis (e.g., see Plate 6, Figs. 10-11). Sensu stricto forms of $G$. crassula possess an imperforate peripheral band.

\section{Globorotalia fohsi s.l. Cushman and Ellisor Plate 3, Figs. 1-4}

Globorotalia fohsi Cushman and Ellisor, 1939, p. 12, pl. 2, figs. 6a-c. Globorotalia lobata Bermudez, 1949, p. 286, pl. 22, figs. 15-17.

Globorotalia fohsi robusta Bolli, 1950, p. 84, 89, pl. 15, figs. 3a-c.

Globorotalia (Fohsella) fohsi fohsi (Cushman and Ellisor) Kennett and Srinivasan, 1983, p. 100 , pl. 23 , figs. 1-3.

Globorotalia (Fohsella) fohsi lobata (Bermudez) Kennett and Srinivasan, 1983 , p. 100, pl. 21 , fig. 2 ; pl. 23, figs. 4-6.

Globorotalia (Fohsella) fohsi robusta (Bolli) Kennett and Srinivasan, 1983, p. 102 , pl. 23 , figs. $7-9$.

Stratigraphic range: Cores 130-806B-48X-2 to $-44 \mathrm{X}-5$ (base of N12-top of N12). 
Remarks: We did not distinguish between Globorotalia fohsi fohsi, G. fohsi lobata, and $G$. fohsi robusta in this study. One reason for lumping these subspecies is the fact that the "cockscomb-like" chambers characteristic of the fully carinate $G$. fohsi lobata also occur on large specimens of partially carinate G. praefohsi (see discussion by Bolli and Saunders, 1985).

Similar species: Globorotalia fohsi s.l. has an imperforate band and/or a thin raised keel around the entire final whorl of its test that distinguishes this group from G. praefohsi, which has an imperforate band and/or a keel on only the last two or three chambers of the final whorl. In this distinction between G. fohsi and G. praefohsi, we follow Kennett and Srinivasan (1983) but differ from Bolli and Saunders (1985). Transitional specimens occur as low as Core 130-806B-49X-CC (e.g., see Plate 3, Figs. 8-10).

\section{Globorotalia juanai Bermudez and Bolli Plate 6, Figs. 17-18}

Globorotalia juanai Bermudez and Bolli, 1969, pp. 171-172, pl. 14, figs. 1-6; Bolli and Saunders, 1985, p. 216, figs. 30.20-21a-c and 30.22-24.

Globorotalia (Hirsutella) juanai (Bermudez and Bolli) Kennett and Srinivasan, 1983, p. 134, pl. 31, figs. 6-8.

Stratigraphic range: Cores $130-806 \mathrm{~B}-31 \mathrm{H}-5$ to $-17 \mathrm{H}-\mathrm{CC}$ (upper N16lower N18/N19).

Similar species: Globorotalia juanai differs from $G$. cibaoensis in having a subrounded to subacute peripheral margin as opposed to the subangular to acute margin of the latter taxon. $G$. juanai also tends to be flatter on the dorsal side with inflated chambers on the ventral side. It differs from $G$. crassula in being less circular in outline and in lacking an angular, keel-like peripheral margin.

\section{Globorotalia lenguaensis s.1. Bolli} Plate 7, Figs. 16-20

Globorotalia lenguaensis Bolli, 1957, p. 120, pl. 29, figs. 5a-c.

Globorotalia (Globorotalia) paralenguaensis Blow, 1969, p. 402, pl. 46, figs. 1-6.

Globorotalia (Globorotalia) lenguaensis (Bolli) Kennett and Srinivasan, 1983, p. 152 , pl. 29 , figs. $5 \mathrm{a}-\mathrm{c}$.

Globorotalia (Globorotalia) paralenguaensis (Blow) Kennett and Srinivasan, 1983, p. 154, pl. 37, figs. 1-3.

Stratigraphic range: Cores $130-806 \mathrm{~B}-46 \mathrm{X}-\mathrm{CC}$ to $-20 \mathrm{H}-5$ (lower N12upper N17b).

Remarks: Occasionally a common species, particularly in the upper part of Zone N12 and the lower part of Zone N13. Its ultrastructure is very similar to the $G$. fohsi group. G. lenguaensis seems prone to dissolution, and the inner whorls on the spiral side are often corroded and pitted. Blow (1969) and Kennett and Srinivasan (1983) suggest that Globorotalia paralenguaensis is an evolutionary intermediate between $G$. lenguaensis and $G$. merotumida. $G$. lenguanensis is circular in outline, whereas G. paralenguaensis is more oblate. However, both forms co-occur throughout their range, and they are highly gradational at this site; therefore, the two were not separated. G. lenguaensis s.l. is characterized by its smooth, finely perforate test and imperforate peripheral band. The peripheral outline varies from rounded to subangular.

Similar species: $G$. lenguaensis s.l. differs from $G$. merotumida in possessing more numerous chambers, typically six to six and a half as opposed to five to five and a half, and in lacking a raised keel. G. lenguaensis s.l. closely resembles the $G$. fohsi group in Zone N12, but it is distinguished by its smaller size and absence of a raised keel.

\section{Globorotalia limbata (Fornasini)} Plate 5, Fig. 10

Rotalia limbata Fornasini, 1902, pp. 30-31, pl. 5, fig. 3 (lectotype). Globorotalia (Menardella) limbata (Fornasini) Kennett and Srinivasan, 1983, p. 124 , pl. 29 , figs. $4-6$.

Stratigraphic range: Cores $130-806 \mathrm{~B}-34 \mathrm{H}-2$ to $-3 \mathrm{H}-\mathrm{CC}$ (mid N16-mid N22/N23).

Remarks: This "species" is essentially a Globorotalia menardii with seven to eight chambers in the final whorl, rather than five to six and a half.

Similar species: Six to six and a half chambered specimens of "menardiiform" taxa are problematic, and using the shape of the spiral sutures as a secondary distinguishing characteristic is difficult as all degrees of "limbation" may be observed. Such forms are assigned, therefore, to $G$. menardii s.l. $G$. limbata is gradational with $G$. multicamerata. Seven- to eight-chambered forms were assigned to $G$. limbata, whereas nine-chambered forms were assigned to G. multicamerata. G. limbata is more oblate than G. pseudomiocenica and is less vaulted on the umbilical side. Kennett and Srinivasan (1983) consider G. pseudomiocenica to be a junior synonym of $G$. limbata. G. limbata has a thicker test than $G$. pertenuis.

\section{Globorotalia margaritae Bermudez and Bolli} Plate 6, Figs. 5-9

Globorotalia margaritae Bolli and Bermudez, 1965, p. 138, pl. 1, figs. 1-9; Bolli and Saunders, 1985, p. 216, 30.1-5 and 30.9-14.

Globorotalia (Hirsutella) margaritae (Bolli and Bermudez) Kennett and Srinivasan, 1983, p. 136, pl.. 32, figs. 4-6; Bolli and Saunders, 1985.

Stratigraphic range: Cores $130-806 \mathrm{~B}-18 \mathrm{H}-5$ to $-9 \mathrm{H}-5$ (lower N18/N19top of N19/N20).

Remarks: Astrict species concept was applied to Globorotalia margaritae in Hole 806B. It is a useful lower Pliocene marker species. Its FO is between the $\mathrm{FO}$ of $G$. tumida and the LO of Globoquadrina dehiscens in the basal Pliocene of Hole 806B. Its LO is slightly below the FO of Globorotalia tosaensis at the Zone N19-N20/N21 boundary.

Similar species: $G$. margaritae differs from $G$. cibaoensis, G. crassula, and $G$. juanai in being concavo-convex and having an angular margin with a thin keel.

\section{Globorotalia menardii s.l. (Parker, Jones and Brady)} Plate 5, Figs. 7-9 and 15

Rotalia menardii Parker, Jones, and Brady, 1865, p. 20, pl. 3, fig. 81; Bolli and Saunders, 1985 , p. $220,34.1-10$

Globorotalia (Menardella) menardii (Parker, Jones, and Brady) Kennett and Srinivasan, 1983, p. 124, pl. 28, fig. 2; pl. 29, figs. 1-3.

Stratigraphic range: Cores $130-806 \mathrm{~B}-44 \mathrm{X}-2$ to $-1 \mathrm{H}-2$ (base of N13-top of N22/N23)

Remarks: Globorotalia menardii s.l. exhibits considerable morphological variation. It ranges greatly in overall size. Throughout the range of this species, test texture may be quite smooth and glassy to rough and encrusted with secondary calcite. One test texture tends to dominate any given sample. The overall outline of the test ranges from nearly circular to oblate. In edge view the species is biconvex with a keel ranging from heavy to thin.

Similar species: Heavily keeled, rough, and encrusted specimens of Globorotalia menardii s.l. can be mistaken for G. tumida, particularly in intervals (e.g., Miocene/Pliocene boundary interval) where all menardiiform specimens are also oblate in outline (e.g., Plate 5, Fig. 8). G. tumida, however, is aysmmetrically biconvex, being more highly vaulted on the ventral side, and it is consistently tumid and tapered in edge view (i.e., swollen on the end opposite the final chamber). G. menardii s.l. is more equally biconvex and is thinner in edge view than the merotumida-plesiotumida-tumida lineage. G. menardii has five to six and a half chambers in its final whorl, whereas $G$. limbata has seven to eight and $G$. multicamerata has at least nine chambers in its final whorl. G. pseudomiocenica is very similar to $G$. menardii s.l. but it tends to have a more circular and less lobate outline and to be more highly vaulted on the umbilical side. G. menardii s.l. has a thicker test than $G$. pertenuis.

\section{Globorotalia merotumida Blow and Banner} Plate 7, Figs. 11-15

Globorotalia (Globorotalia) merotumida Blow and Banner, 1965, p. 1352 , text fig. 1; Kennett and Srinivasan, 1983, p. 154, pl. 37, figs. 4-6.

Globorotalia merotumida (Blow and Banner) Bolli and Saunders, 1985. p. 227 , fig. 33.7 .

Stratigraphic range: Cores $130-806 \mathrm{~B}-27 \mathrm{H}-5$ to $-18 \mathrm{H}-5$ (lower N16lower N18/N19).

Remarks: This is a small species. In edge view its umbilical side is slightly more highly vaulted than its spiral side. Its test wall is finely perforate but smooth.

Similar species: Globorotalia plesiotumida is derived from G. merotumida, and the two taxa are commonly gradational. G. plesiotumida tends to be slightly larger than $G$. merotumida. However, the most reliable character for differentiating between them is the proportions of the final chamber viewed 
from the spiral side. Specimens in which the width of the final chamber exceeds the radial length are $G$. merotumida. Individual specimens whose dimensions are nearly equal are assigned to $G$. plesiotumida.

\section{Globorotalia cf. G. miozea Finlay \\ Plate 4, Figs. 12 and $17-18$}

Globorotalia miozea Finlay, 1939, p. 326, pl. 29, figs. 159-161.

Globorotalia (Globoconella) miozea (Finlay) Kennett and Srinivasan, 1983, p. 112 , pl. 24, fig. 2; pl. 26, figs. 1-3.

Stratigraphic range: Cores 130-806B-58X-2 to -47X-CC (lower N8/N9_ lower N12).

Remarks: Like Globorotalia cf. G. zealandica, very rare specimens of this temperate-latitude species occur in Hole 806B and, again like $G$. cf. $G$. zealandica, they are much smaller than typical temperate zone specimens.

Similar species: See Globorotalia zealandica for comparison with that species. The angular, nearly keeled margin and highly vaulted umbilical side of G. cf. G. miozea distinguish it from G. praescitula. G. conoidea has a keel and raised sutures on its spiral side (Kennett and Srinivasan, 1983). The latter taxon was not observed in Hole 806B.

Globorotalia peripheroacuta Blow and Banner Plate 3, Figs. 14-15

Globorotalia (Turborotalia) peripheroacuta Blow and Banner, 1966, p. 294. pl. 1, figs, 2a-c.

Globorotalia (Fohsella) peripheroacuta (Blow and Banner) Kennett and Srinivasan, 1983, p. 96, pl. 22, figs. 4-6.

Globorotalia fohsi peripheroacuta (Blow and Banner) Bolli and Saunders, 1985 , p. 213 , figs. $29.5 \mathrm{a}-\mathrm{c}$ and $29.13 \mathrm{a}-\mathrm{c}$.

Stratigraphic range: Cores $130-806 \mathrm{~B}-53 \mathrm{X}-\mathrm{CC}$ to $-47 \mathrm{X}-\mathrm{CC}$ (base of N10-lower N12).

Similar species: Globorotalia peripheroacuta has a distinctly more angular (subacute to acute) peripheral margin than does $G$. peripheroronda, particularly in the last formed chambers, but it is noncarinate, which serves to distinguish $G$. peripheroacuta from $G$. praefohsi.

\section{Globorotalia peripheroronda Blow and Banner}

Plate 3, Figs. 11 and 19-20

Globorotalia (Turborotalia) peripheroronda Blow and Banner, 1966, p. 294. pl. 1, figs. la-c.

Globorotalia (Fohsella) peripheroronda (Blow and Banner) Kennett and Srinivasan, 1983, p. 96, pl. 22, figs. 1-3.

Globorotalia fohsi peripheroronda (Blow and Banner) Bolli and Saunders, 1985 , p. 213 , figs. $29.6 a-c$ and $29.14 a-c$.

Stratigraphic range: Cores $130-806 \mathrm{~B}-72 \mathrm{X}-\mathrm{CC}$ to $-50 \mathrm{X}-\mathrm{CC}$ (mid N4blower N11).

Similar species: Globorotalia peripheroronda has a round to subround peripheral margin compared with the subacute to acute margin of $G$. peripheroacuta. G. peripheroronda is more oblate in equatorial outline than $G$. birnageae. G. peripheroronda is gradational with both of these taxa. Paragloborotalia mayeri has more inflated chambers and a higher arched aperture.

\section{Globorotalia cf. G. pertenuis Beard} Plate 5, Figs. 5-6

Globorotalia pertenuis Beard, 1969, p. 552, pl. 1, figs. 1-6; pl. 2, figs. 5-6; Bolli and Saunders, 1985, p. 220, 33.3a-c.

Globorotalia (Menardella) pertenuis (Beard) Kennett and Srinivasan, 1983, p. 130 , pl. 30 , figs. $7-9$.

Stratigraphic range: Cores $130-806 \mathrm{~B}-24 \mathrm{H}-2$ to $-21 \mathrm{H}-\mathrm{CC}$ (upper N17alower N17b).

Similar species: $G$. cf. pertenuis is gradational with $G$. menardii s.l. and G. limbata, but it can be distinguished from the latter taxa by its distinctively thinner test and narrow, nearly closed umbilicus.

Globorotalia plesiotumida Blow and Banner Plate 7, Figs. 1-2 and 6-10

Globorotalia (Globorotalia) tumida (Brady) plesiotumida Blow and Banner, 1965 , p. 1353 , figs. $2 a-c$.
Globorotalia (Globorotalia) plesiotumida (Blow and Banner) Kennett and Srinivasan, 1983, p. 156, p. 37, figs. 7-9.

Globorotalia plesiotumida (Blow and Banner) Bolli and Saunders, 1985, p. 227 , fig. 33.5 .

Stratigraphic range: Cores $130-806 \mathrm{~B}-29 \mathrm{H}-3$ to $-13 \mathrm{H}-5$ (base of N17aupper N18/N19).

Remarks: In umbilical view, Globorotalia plesiotumida is oblate in general outline. Its chambers are highly vaulted on the umbilical side. Its spiral side may be nearly flat to slightly convex, making it distinctively asymmetrical in edge view.

Similar species: The proportions of the final chamber (see G. merotumida) are the most reliable character for distinguishing this species from $G$. merotumida. The final chamber of $G$. plesiotumida often looks more lobate and protruding than earlier chambers because of its greater radial length to width ratio. $G$. plesiotumida is distinguished from its descendent $G$. tumida by its generally smaller size, less tumid test, more pronounced asymmetrical edge view, and thinner peripheral keel. G. plesiotumida is generally intermediate in size between $G$. merotumida and $G$. tumida.

\section{Globorotalia praefohsi Blow and Banner} Plate 3, Figs. 5-7

Globorotalia (Globorotalia) praefohsi Blow and Banner, 1966, p. 295, pl. 1, figs. $3-4$; pl. 2, figs. 6-7 and 10-11.

Globorotalia (Fohsella) praefohsi (Blow and Banner) Kennett and Srinivasan, 1983, p. 98, pl. 22, figs. 7-9.

Globorotalia fohsi praefohsi (Blow and Banner) Bolli and Saunders, 1985, p. 213 , figs. 29.3a-c and $29.11 \mathrm{a}-\mathrm{b}$.

Stratigraphic range: Cores $130-806 \mathrm{~B}-51 \mathrm{X}-\mathrm{CC}$ to $-41 \mathrm{X}-5$ (base of N11upper N13),

Similar species: Globorotalia praefohsi possess an imperforate band or thin keel on the last two or three chambers. The degree of keel development is used to distinguish G. peripheroacuta (noncarinate), G. praefohsi (partially carinate), and $G$. fohsi s.l. (fully carinate).

\section{Globorotalia praemenardii Cushman and Stainforth} Plate 5, Figs. 12-14

Globorotalia praemenardii Cushman and Stainforth, 1945, p. 70, pl. 13, figs. 14a-c; Bolli and Saunders, 1985, p. 220, 32.7a-c.

Globorotalia (Menardella) praemenardii (Cushman and Stainforth) Kennett and Srinivasan, 1983, p. 122, pl. 28, figs. 6-8.

Stratigraphic range: Cores $130-806 \mathrm{~B}-54 \mathrm{X}-2$ to $-40 \mathrm{X}-5$ (top of N8/N9lower N14).

Remarks: This species is never as common at this site as its descendent Globorotalia menardii.

Similar species: In a given sample, the average size of this species is smaller than that of co-occurring specimens of $G$. menardii. The keel of $G$. praemenardii is also thinner and less distinct than $G$. menardii. See $G$. archeomenardii.

\section{Globorotalia praescitula Blow}

Plate 4, Figs. 7-11

Globorotalia scitula (Brady) subsp. praescitula Blow, 1959, p. 221, pl. 19, figs. 128a-c.

Globorotalia (Globoconella) praescitula (Blow) Kennett and Srinivasan, 1983, p. 108, pl. 24, fig. 1; pl. 25, figs. 4-6.

Stratigraphic range: Cores 130-806B-63X-2 to -51X-5 (upper N5lower N11).

Similar species: See Globorotalia zealandica. Globorotalia praescitula is smaller, larger pored, and more lobate. G. scitula has a more circular outline. By these criteria, no stratigraphic overlap exists between these two species in Hole 806B.

\section{Globorotalia pseudomiocenica Bolli and Bermudez} Plate 5, Figs. 1-4

Globorotalia pseudomiocenica Bolli and Bermudez, 1965, p. 140, pl. 1, figs. 13-15; Bolli and Saunders, 1985, p. 230, figs. 31.1 and 35.1-3. 
Stratigraphic range: Cores $130-806 \mathrm{~B}-25 \mathrm{H}-5$ to $-14 \mathrm{H}-\mathrm{CC}$ (upper 17bmid N18/N19).

Similar species: Globorotalia pseudomiocenica is more highly vaulted on the umbilical side than are G. menardii s.l. and $G$. limbata, and it is more circular and less lobate in outline than the latter two taxa. It is slightly larger and has more chambers than $G$. merotumida.

Globorotalia scitula (Brady)

Plate 4, Fig. 6; Plate 6, Figs. 15-16

Pulvinulina scitula Brady, 1882, p. 27, pl. 5, fig. 5 (lectotype).

Globorotalia (Hirsutella) scitula (Brady) Kennett and Srinivasan, 1983, p. 134, pl. 31, figs. 1 and $3-5$.

Stratigraphic range: Cores 130-806B-4IX-CC to -2H-5 (upper N13-upper N22/N23).

Remarks: Never common, but occurring fairly consistently throughout its range.

Similar species: Globorotalia cibaoensis has a rougher, more opaque surface, often with a suggestion of a keel on the final chamber. The spiral sutures of $G$. scitula are more strongly curved than those of $G$. cibaoensis. $G$. juanai tends to be smaller, more opaque, and less circular in outline; the chambers are more inflated and more highly vaulted on the umbilical side. See G. praescitula.

Globorotalia tosaensis Takaynagi and Saito Plate 6, Figs. 1-2

Globorotalia tosaensis Takayanagi and Saito, 1962, p. 81, pl. 28, figs. 11a12c; Lamb and Beard, 1972, p. 56, pl. 22, figs. 1-7, pl. 23, figs. 1-2; Jenkins and Orr, 1972, p. 1104, pl. 33, figs. 1-3; Stainforth et al., 1975, p. 413, figs. 206-207.

Globorotalia tosaensis tosaensis (Takayanagi and Saito) Bolli and Saunders, 1985 , p. 234, fig. 37.8 .

Globorotalia (Truncorotalia) tosaensis (Takayanagi and Saito) Kennett and Srinivasan, 1983, p. 148, pl. 34, fig. 1; pl. 35, figs. 1-3.

Stratigraphic range: Cores 130-806B-9H-2 to -2H-CC (base of N21mid N22/N23).

Remarks: Based on its rarity in tropical regions and its widely accepted relation to Globorotalia truncatulinoides (Kennett and Srinivasan, 1983), this species is thought to have been primarily a temperate-latitude dweller. $G$. tosanensis has five to five and a half chambers in its final whorl. These chambers are rounded and perforate through their edges. The umbilical apices are also rounded. The texture of the test is often rough, heavily encrusted with secondary calcite. The thin-shelled "tenuitheca" form is too rare at this site to be of stratigraphic value.

Similar species: Srinivasan and Kennett (1981b) note that, although a simple gradation is present between G. tosaensis and G. truncatulinoides at DSDP Site $206\left(32^{\circ} \mathrm{S}, 165^{\circ} \mathrm{E}\right.$ in the New Caledonia Basin), further north at DSDP Site $208\left(26^{\circ} \mathrm{S}, 161^{\circ} \mathrm{E}\right.$ on the North Howe Rise $)$ "the relative abundance of the two forms fluctuates significantly within the interval of overlap." Scanning electron microscopy of many specimens from Site 806 reveals a continuous morphological cline between the two species with respect to perforation along the periphery. Imperforation was generally best developed on the oldest chamber in the final whorl. A specimen was designated $G$. truncatulinoides if this chamber had an imperforate band. Globorotalia crassaformis has only four to four and a half chambers in its final whorl and is distinctly more lobate in equatorial outline than either $G$. tosaensis or $G$. truncatulinoides.

\section{Globorotalia truncatulinoides (d'Orbigny)} Plate 6, Figs. 3-4

Rotalia truncatulinoides d'Orbigny, 1839, p. 132, pl. 2, figs. 25-27. Globorotalia truncatulinoides (d'Orbigny) Lamb and Beard, 1972, p. 56, pl. 24 , figs. $1-4$, pl. 25, figs. 1-7, pl. 26, figs. 1-3; Jenkins and Orr, 1972; p. 1104, pl. 33, figs. 4-6; Stainforth et al., 1975, figs. 209-211.

Globorotalia truncatulinoides truncatulinoides (d'Orbigny) Bolli and Saunders, 1985 , p. 234 , fig. $37.4-37.5$

Globorotalia (Truncorotalia) truncatulinoides (d'Orbigny) Kennett and Srinivasan, 1983 , p. 148 , pl. 34 , fig. 2 ; pl. 35, figs. 4-6.

Stratigraphic range: Cores $130-806 \mathrm{~B}-6 \mathrm{H}-5$ to $-2 \mathrm{H}-2$ (N22/N23).
Remarks: In its sensu stricto form, this species possesses a raised keel; however, many early forms show only an imperforate band, particularly on the earliest formed chamber of the final whorl. At Site 806 no obvious stratigraphic progression toward the development of the raised keel was observed. The deepest specimens have a distinct keel around the entire periphery; therefore, the presence or absence of a raised keel was probably a function of the degree of secondary calcification during ontogeny.

Similar species: See Globorotalia tosaensis.

\section{Globorotalia tumida (Brady)}

Plate 7, Figs. 3-5

Pulvinulina menardii (d'Orbigny) var, tumida Brady, 1877, pl. 103, figs. 4-6. Globorotalia (Globorotalia) tumida tumida (Brady) Kennett and Srinivasan, 1983, p. 158, pl. 36, fig. 1; pl. 38, figs. 1-3.

Stratigraphic range: Cores $130-806 \mathrm{~B}-19 \mathrm{H}-3$ to $-1 \mathrm{H}-2$ (base of N18/N19top of N22/N23).

Remarks: Globorotalia tumida s.s. is swollen ("tumid") at the end opposite its final chamber. Its keel is consistently heavy and often wide. The texture of the test is rough and encrusted with secondary calcite, particularly around the umbilicus. The general outline of the umbilical view of this species is consistently oblate.

Similar species: Especially tumid Globorotalia menardii are common in some samples. These specimens are distinguished from $G$. tumida by any combination of the the following characteristics: greater symmetry of biconvexity, smoother wall texture, and/or more circular equatorial outline. G. merotumida is smaller with a smoother test wall and thinner keel. See G. plesiotumida.

\section{Globorotalia ungulata Bermudez}

Globorotalia ungulata Bermudez, 1960, p. 1304, pl. 15, figs. 6a-b. Globorotalia (Globorotalia) ungulata (Bermudez) Kennett and Srinivasan, 1983 , p. 160 , pl. 36 , figs. $3-4$; pl. 38, figs. 7-9.

Stratigraphic range: Cores $130-806 \mathrm{~B}-12 \mathrm{H}-5$ to $-1 \mathrm{H}-2$ (upper N18/N19 to upper N22/N23).

Similar species: The smooth finely perforate texture distinguishes this species from Globorotalia tumida, which is always a rough textured species. In Hole 806B, unusually deep records of $G$. ungulata cause its range to overlap with that of $G$. plesiotumida, with which it shares an oblong form and a final chamber that, on the spiral side, is longer radially than it is wide. Both species are also more inflated on the umbilical side, and the most reliable way to separate them is by the smooth glassy texture and higher dorsal spire of $G$. ungulata.

\section{Globorotalia cf. G. zealandica Hornibrook Plate 4, Figs. 13-16}

Globorotalia zealandica Hornibrook, 1958, p. 667, figs. 18, 19, and 30. Globorotalia (Globoconella) zealandica (Hornibrook) Kennett and Srinivasan, 1983, p. 108, pl. 25, figs. 1-3.

Stratigraphic range: Cores $130-806 \mathrm{~B}-56 \mathrm{X}-4$ to $-55 \mathrm{X}-2$ (upper N8/N9). Remarks: This is a temperate-zone species that is very rare at this tropical site. Specimens at Site 806 are tiny.

Similar species: This species resembles Globorotalia praescitula, but that species generally has four and half rather than just four chambers in the final whorl. The sutures on the spiral side of a $G$. praescitula are more strongly curved. The chambers on the umbilical side of $G$. cf. $G$. zealandica are more inflated than those of $G$. praescitula. Globorotalia miozea is more sharply vaulted on the umbilical side and has a distinctly angular periphery on the chambers in the final whorl.

\section{Globorotaloides hexagona (Natland)} Plate 9, Fig. 4

Globigerina hexagona Natland, 1938, p. 149, pl. 7, figs. 1a-c.

Globorotaloides hexagona (Natland) Kennett and Srinivasan, 1983, p. 216. pl. 54, figs. 1, 3-5.

Stratigraphic range: Cores 130-806B-58X-CC to -1H-2 (lower N8/N9top of N22/N23).

Remarks: This is a relatively rare species in Hole 806B. The spiral side is nearly flat, and the sutures on the spiral side are radial or slightly curved. There 
are usually five chambers in the final whorl, but individuals with four were also found. Often the final chamber is much larger than the penultimate chamber. The aperture is arched slightly and bordered by a rim or a narrow plate. The wall is coarsely cancellate.

Similar species: Neogloboquadrina dutertrei is not as distinctly cancellate, and the chambers do not increase as rapidly in size as those of Globorotaloides hexagona. Also see $G$. variabilis.

\section{Globorotaloides suteri Bolli}

Plate 9, Fig. 2

Globorotaloides suteri Bolli, 1957, p. 117, pl. 27, figs. 9a-13b; Kennett and Srinivasan, 1983, p. 214, pl. 53, figs. 1 and 3-5.

Stratigraphic range: Cores $130-806 \mathrm{~B}-78 \mathrm{X}-\mathrm{CC}$ to $-59 \mathrm{X}-5$ (base of N4abase of N8/N9).

Similar species: Globorotaloides suteri has more inflated chambers than G. variabilis, and it lacks the subacute peripheral margin of the latter taxon. $G$. hexagona is thinner and has more lobate chambers than $G$. suteri.

\section{Globorotaloides variabilis Bolli}

Plate 9, Fig. 3

Globorotaloides variabilis Bolli, 1957, p. 117, pl. 27, figs. 15a-20c; Kennett and Srinivasan, 1983, p. 214 , pl. 53 , figs. 2 and 6-8.

Stratigraphic range: Cores $130-806 \mathrm{~B}-53 \mathrm{X}-4$ to $-6 \mathrm{H}-5$ (lower N10-base of N22/N23).

Similar species: Globorotaloides variabilis can resemble juvenile specimens of Globoquadrina venezuelana and $G$. conglomerata, but it can be distinguished from these taxa by its distinctive subacute margin on the early chambers of the final whorl and the lack of an apertural tooth-plate. The chambers of $G$. variabilis are more embracing than those of $G$. hexagona. The subacute peripheral margin of $G$. variabilis also serves to distinguish these two taxa.

Neogloboquadrina acostaensis (Blow)

Plate 8, Fig. 5

Globorotalia acostaensis Blow, 1959, p. 208, pl. 17, figs. 106a-c.

Neogloboquadrina acostaensis (Blow) Kennett and Srinivasan, 1983, p. 196, pl. 47 , fig. 1 ; pl. 48 , figs. $1-3$.

Stratigraphic range: Cores $130-806 \mathrm{~B}-38 \mathrm{X}-4$ to $-16 \mathrm{H}-5$ (base of N16mid N18/N19).

Remarks: Many specimens of this species found at this site are relatively large, more nearly the size of Neogloboquadrina humerosa.

Similar species: Large specimens resemble $N$. humerosa, but the latter species lacks an apertural flap, its aperture is more open, and it usually has six chambers in the final whorl (e.g., see Plate 8, Fig. 6). N. acostaensis differs from Globorotalia challengeri in possessing an apertural flap or kümmerformlike final chamber, and in being uniformly perforate. See $G$. challengeri.

\section{Neogloboquadrina continuosa (Blow)}

Plate 8, Figs. 12-15

Globorotalia opima Bolli subsp. continuosa Blow, 1959, p. 218, pl. 19, figs. $125 \mathrm{a}-\mathrm{c}$.

Neogloboquadrina continuosa (Blow) Kennett and Srinivasan, 1983, p. 192 , pl. 47 , figs. $3-5$.

Stratigraphic range: Cores $130-806 \mathrm{~B}-78 \mathrm{X}-\mathrm{CC}$ to $-41 \mathrm{X}-\mathrm{CC}$ (lower N4 upper N13).

Similar species: Neogloboquadrina continuosa is separated from Paragloborotalia nana by its more lobate chambers and a distinctively arched aperture.

\section{Neogloboquadrina dutertrei (d'Orbigny) Plate 8, Fig. 4}

Globigerina dutertrei d'Orbigny, 1839, pl. 2, fig. 1 (lectotype).

Neogloboquadrina dutertrei (d'Orbigny) Kennett and Srinivasan, 1983, p. 198, pl. 48, figs. 7-9.

Stratigraphic range: Cores $130-806 \mathrm{~B}-23 \mathrm{H}-2$ to $-1 \mathrm{H}-2$ (top of N17a-top of $\mathrm{N} 22 / \mathrm{N} 23$ ).
Similar species: In Hole 806B, the ranges of $N$. dutertrei and $N$. acostaensis overlap from the top of Subzone N17a to the middle of Zone N18/N19. N. dutertrei has more inflated chambers, a coarser cancellate texture, and a more open aperture. Its apertural flap, when present, rarely covers the aperture completely (e.g., see Plate 8, Fig. 9). See $N$. humerosa.

\section{Neogloboquadrina humerosa (Takayanagi and Saito)} Plate 8 , Figs. 7-8

Globorotalia humerosa Takayanagi and Saito, 1962, p. 78, pl. 28, figs. 1a-2b. Neogloboquadrina humerosa (Takayanagi and Saito) Kennett and Srinivasan,

1983, p. 196, pl. 28, figs. 1a-2b.

Stratigraphic range: Cores $130-806 \mathrm{~B}-34 \mathrm{H}-\mathrm{CC}$ to $-7 \mathrm{H}-5$ (mid N16-upper N21).

Remarks: Neogloboquadrina humerosa sensu stricto is very rare at this site. Specimens with only five chambers in the final whorl, but with "an interiomarginal, umbilical-extraumbilical aperture with a distinct rim" (Kennett and Srinivasan, 1983) and a flat dorsal side were assigned to this species concept. Specimens that resembled an intergrade between $N$. humeros $a$ and $N$. dutertrei were found as low as the middle part of Zone N16 in Hole 806B.

Similar species: Neogloboquadrina dutertrei tends to have slightly higher and more variable dorsal convexity than $N$. humerosa, as well as the tendency to develop umbilical plates.

\section{Orbulina suturalis Brönnimann}

Orbulina suturalis Brönnimann, 1951, p. 135, text fig. IV, figs. 15, 16, and 20; Kennett and Srinivasan, 1983, p. 86, pl. 20, figs. 1-3.

Stratigraphic range: Cores 130-806B-51X-CC to $-1 \mathrm{H}-5$ (base of N11upper N22/N23).

Orbulina universa d'Orbigny

Orbulina universa d'Orbigny, 1839, p. 3, pl. 1, fig. 1; Kennett and Srinivasan, 1983 , p. 86 , pl. 20 , figs. $4-6$.

Stratigraphic range: Cores $130-806 \mathrm{~B}-52 \mathrm{X}-5$ to $-1 \mathrm{H}-5$ (top of N10N22/N23).

Remarks: The Zone N8/N9 boundary could not be established at this site because the first occurence of both Orbulina species was high in Hole 806B with respect to other published records (e.g., Kennett and Srinivasan, 1983; Berggren et al., 1985b), indicating paleoenvironmental rather than evolutionary controlling factors.

\section{Paragloborotalia kugleri (Bolli) \\ Plate 3, Figs. 16-18}

Globorotalia kugleri Bolli, 1957, p. 118, pl. 28, figs. 5a-b; Kennett and Srinivasan, 1983, p. 94 , pl. 21, figs. 1 and 3-5.

Paragloborotalia kugleri (Bolli) Spezzaferri, 1991, p. 317, pl. 1, fig. 5a-c, pl. 2 , figs $1 \mathrm{a}-\mathrm{d}$ and $2 \mathrm{a}-\mathrm{d}$.

Stratigraphic range: Cores $130-806 \mathrm{~B}-78 \mathrm{X}-\mathrm{CC}$ to $69 \mathrm{X}-2$ (base of N4atop of N4b).

Similar species: Paragloborotalia kugleri differs from $P$. pseudokugleri in having a subrounded to subangular peripheral margin, a nearly flat dorsal side, and curved dorsal sutures. P. kugleri is smaller than P. mayeri, and it has a lower arched aperture and subangular peripheral margin. Globorotalia peripheroronda tends to be more oblate, have fewer chambers, and have a more biconvex equatorial outline.

\section{Paragloborotalia mayeri Cushman and Ellisor} Plate 8, Figs. 16-20

Globorotalia mayeri Cushman and Ellisor, 1939, p. 11, pl. 2, figs. 4a-c. Globorotalia siakensis LeRoy, 1939, p. 262, pl. 4, figs. 20-22.

Globorotalia (Jenkinsella) mayeri (Cushman and Ellisor) Kennett and Srinivasan, 1983, p. 174, pl. 43, figs. 4-6.

Globorotalia (Jenkinsella) siakensis (LeRoy) Kennett and Srinivasan, 1983, p. 172 , pl. 42 , figs. 1 and $6-8$.

Stratigraphic range: Cores $130-806 \mathrm{C}-60 \mathrm{X}-\mathrm{CC}$ to $130-806 \mathrm{~B}-39 \mathrm{X}-5$ (upper P22-top of N14). 
Remarks: Globorotalia semivera is included under this species concept because of the highly gradational nature of these forms in the lower Miocene (see Leckie et al., this volume). Assignment to the genus Paragloborotalia is based on Spezzaferri's (1991) classification of the spinose "opima" group and derivation of Paragloborotalia mayeri from the "opima" group cf. Kennett and Srinivasan (1983). However, no spine holes where observed upon SEM examination of several specimens.

In samples where this was the dominant species, it represented a larger percentage of the assemblage than did any other large species through the entire record at this site.

Similar species: See Globorotalia challengeri. Neogloboquadrina continuosa is similar to P. mayeri, but it only has four chambers in the final whorl. $P$. mayeri is distinquished from Globorotalia peripheroronda by its more inflated chambers and higher arched aperture.

\section{Paragloborotalia nana Bolli Plate 8, Figs. 10-11}

Globorotalia opima nana Bolli, 1957, p. 118, pl. 28, figs. 3a-c.

"Globorotalia" nana (Bolli) Kennett and Srinivasan, 1983, p. 106, pl. 24, figs. 3-5.

Stratigraphic range: Cores $130-806 \mathrm{C}-60 \mathrm{X}-\mathrm{CC}$ to $130-806 \mathrm{~B}-47 \mathrm{X}-\mathrm{CC}$ (upper P22-lower N12).

Remarks: This species is a member of the spinose "opima" group, which is assigned to the genus Paragloborotalia (Spezzaferri, 1991). Bolli and Saunders (1985, p. 206) describe a gradual evolution of "Globorotalia continuosa" from "G. opima nana."

Similar species: $P$. nana differs from $P$. continuosa in having a lower arched aperture and more embracing chambers.

\section{Paragloborotalia pseudokugleri (Blow)}

Globorotalia cf. G. kugleri Bolli, 1957, pl. 28, figs. 7a-c.

Globorotalia (Turborotalia) pseudokugleri Blow, 1969, p. 391, pl. 10, figs. $4-6$; pl. 39, figs. 5-6.

Paragloborotalia pseudokugleri (Blow) Spezzaferri, p. 315, pl. 1, figs. 1-4.

Stratigraphic range: Cores $130-806 \mathrm{C}-60 \mathrm{X}-\mathrm{CC}$ to $130-806 \mathrm{~B}-72 \mathrm{X}-\mathrm{CC}$ (upper P22-mid N4b).

Remarks: Leckie et al. (this volume) present numerous illustrations of Paragloborotalia pseudokugleri with emphasis on its distinction from $P$. kugleri.

Similar species: Paragloborotalia pseudokugler is distinquished from $P$. kugleri by its rounded peripheral margin, radial dorsal sutures, and tendency to be more circular in equatorial outline.

\section{Praeorbulina sicana (DeStefani)}

Plate 2, Figs. 5-6

Globigerinoides sicanus DeStefani, 1950, p. 9, fig. 6; Kennett and Srinivasan, 1983 , p. 62 , pl. 13 , figs. 4-6.

Praeorbulina sicana (DeStefani) Bolli and Saunders, 1985, p. 199, fig. 24.7.

Stratigraphic range: Cores 130-806B-59X-5 to -53X-CC (base N8/N9base of N10).

Remarks: Kennett and Srinivasan (1983) acceded to the view of Jenkins et al. (1981) that this species is distinct from Globigerinoides bisphericus and belongs in the genus Praeorbulina. Because it is a zonal marker species, we have applied a narrow species concept. In this study, P. sicana must have at least three low apertures at the base of the final chamber (see Jenkins et al., 1981).

Similar species: See Globigerinoides sicana/bisphericus. The final chamber of $P$. sicana tends to be larger and more embracing than $G$. sicana/bisphericus, and it has at least three apertures at the base of the base of the final chamber, compared with two in the latter taxon.

\section{Pulleniatina obliquiloculata (Parker and Jones)}

Pullenia sphaeroides (d'Orbigny) var. obliquiloculata Parker and Jones, 1865 , p. 368 , pl. 19 , figs. $4 a-b$.

Pulleniatina obliquiloculata (Parker and Jones) Kennett and Srinivasan, 1983 , p. 202, pl. 49, fig. 2; pl. 50, figs. 6-9.

Stratigraphic range: Cores $130-806 \mathrm{~B}-14 \mathrm{H}-\mathrm{CC}$ to $-1 \mathrm{H}-2$ (mid N18/N19N22/N23).

Remarks: This species is distinguished from earlier pulleniatinids by an aperture that extends from the umbilical to the spiral side on the final chamber enclosing earlier chambers to varying degrees. Pulleniatina finalis is included under the present species concept (cf. Orr and Jenkins, 1980, and Kennett and Srinivasan, 1983).

Similar species: See Pulleniatina primalis.

Pulleniatina praespectabilis Brönnimann and Resig Plate 8, Fig. 2

Pulleniatina spectabilis praespectabilis Brönnimann and Resig, 1971, p. 1287 , pl. 19, figs. 4 and 7.

Stratigraphic range: Cores $130-806 \mathrm{~B}-18 \mathrm{H}-5$ to $-15 \mathrm{H}-2$ (lower to mid N18/N19).

Similar species: Pulleniatina praespectablilis is gradational between $P$. primalis and sensu stricto forms of $P$. spectabilis. $P$. praespectabilis has a distinctly more subrounded to subacute peripheral margin compared with $P$. primalis, but it is not as planoconvex nor does it have the distinctive peripheral flange of $P$. spectabilis.

\section{Pulleniatina primalis Banner and Blow} Plate 8, Fig. 1

Pulleniatina primalis Banner and Blow, 1967, p. 142, pl. 1, figs. 3-8; pl. 3, figs. 2a-c; Kennett and Srinivasan, 1983, p. 200, pl. 49, figs. 1 and 3-5.

Stratigraphic range: Cores $130-806 \mathrm{~B}-22 \mathrm{H}-\mathrm{CC}$ to $-5 \mathrm{H}-5$ (base of $\mathrm{N} 17 \mathrm{~b}-$ lower $\mathrm{N} 22 / \mathrm{N} 23$ ).

Remarks: In this study, Pulleniatina praecursor has been included under the $P$. primalis species concept (cf. Orr and Jenkins, 1980).

Similar species: P. primalis is gradational with Neogloboquadrina acostaensis in the upper part of Core 130-806B-23H. The FO of $P$. primalis is based on the development of a distinct cortex over much of the test. P. praespectabilis has a subrounded to subacute peripheral outline as compared with the distinctly rounded outline of $P$. primalis. The aperture of $P$. primalis is extraumbilical-umbilical, and the test is entirely trochospirally coiled in contrast to $P$. obliquiloculata, which has an aperture extenting from the umbilicus onto the spiral side because of an ontogenetic change in coiling from trochospiral to streptospiral

\section{Pulleniatina spectabilis Parker} Plate 8, Fig. 3

Pulleniatina spectabilis Parker, 1965, p. 151, text. figs. 1-4; Kennett and Srinivasan, 1983, p. 202, pl. 50, figs. 1-5.

Stratigraphic range: Cores $130-806 \mathrm{~B}-15 \mathrm{H}-2$ to $-12 \mathrm{H}-\mathrm{CC}$ (mid to upper N18/N19).

Remarks: The sensu stricto form of this species has a flange around the edge of the chambers in the final whorl. This feature is most pronounced on the final chamber. The test is nearly planoconvex.

Similar species: See Pulleniatina praespectabilis.

$$
\text { Sphaeroidinella dehiscens (Parker and Jones) }
$$

Sphaeroidina bulloides d'Orbigny var. dehiscens Parker and Jones, 1865, p. 369 , pl. 19 , fig. 5 .

Sphaeroidinella dehiscens (Parker and Jones) Kennett and Srinivasan, 1983, p. 212, pl. 51, fig. 2; pl. 52, figs. 7-9.

Stratigraphic range: Cores 130-806B-13H-CC to -2H-2 (mid N18/N19upper N22/N23). This species is used elsewhere (Kennett and Srinivasan, 1983) as the marker species for the top of Zone N18/base of Zone N19. At Site 806, Sphaeroidinella dehiscens does not occur until the middle of Zone N18/N19 undifferentiated.

Remarks: The secondary aperture on the spiral side is diagnostic. The overall shape of this species is subspherical. A thin, irregular flange often borders the primary aperture. In later specimens the secondary aperture may also be flanged. The cortex is thick and complete, obscuring the final whorl.

Similar species: See Sphaeroidinellopsis paenadehiscens.

$$
\begin{gathered}
\text { Sphaeroidinellopsis disjuncta (Finlay) } \\
\text { Plate 10, Fig. } 16
\end{gathered}
$$

Sphaeroidinella disjuncta Finlay, 1940, p. 467, pl. 67, figs. 224-228.

Sphaeroidinellopsis disjuncta (Finlay) Kennett and Srinivasan, 1983, p. 206, pl. 51, figs. 3-5. 
Stratigraphic range: Cores $130-806 \mathrm{~B}-61 \mathrm{X}-\mathrm{CC}$ to $-50 \mathrm{X}-\mathrm{CC}$ (base of N6-lower N11).

Similar species: Sphaeroidinellopsis disjuncta is gradational with both $S$. seminulina and S. kochii (e.g., see Plate 10, Fig. 17). It is distinquished from these taxa by its coarsely cancellate wall and only weakly developed cortex. $S$. disjuncta is also gradational with Globigerina druryi, from which it is distinguished by its distinctly thickened test wall (e.g., see Plate 10, Fig. 15).

\section{Sphaeroidinellopsis kochi (Caudri) \\ Plate 10, Figs. 10, 14, and 18}

Globigerina kochi Caudri, 1934, text figs. 8a-b.

Sphaeroidinellopsis kochi (Caudri) Kennett and Srinivasan, 1983, pl. 52, figs. 1-3.

Stratigraphic range: Cores $130-806 \mathrm{~B}-47 \mathrm{X}-2$ to $-15 \mathrm{H}-5$ (lower N12mid N18/19),

Remarks: This species is rare in Hole 806B. It always has more than three chambers in the final whorl. They are rounded and not completely covered with a cortex, giving the test a distinctly lobate outline. Where not covered with cortical overgrowth, the test is coarsely cancellate.

Similar species: See Sphaeroidinellopsis seminulina.

\section{Sphaeroidinellopsis paenedehiscens Blow} Plate 10, Fig. 9

Sphaeroidinellopsis paenedehiscens Blow, 1969, p. 386, pl. 30, figs. 4, 5, and 9; Kennett and Srinivasan, 1983, p. 52, figs. $4-6$.

Stratigraphic range: Cores $130-806 \mathrm{~B}-30 \mathrm{H}-\mathrm{CC}$ to $-9 \mathrm{H}-3$ (upper N16-top of N19/N20).

Remarks: This species has three chambers in the final whorl, but they are very embracing and completely covered with cortical overgrowth so that the test is oblate.

Similar species: Sphaeroidinellopsis seminulina may also have three chambers in the final whorl, but its chambers are less embracing, giving the test a more lobate equatorial outline. $S$. paenedehiscens evolved into Sphaeroidinella dehiscens by developing a secondary aperture on the spiral side. Early $S$. dehiscens may have only the smallest crack in the spiral side and must be checked carefully.

\section{Sphaeroidinellopsis seminulina (Schwager)} Plate 10, Figs. 8 and $11-13$

Globigerina seminulina Schwager, 1866, p. 256, pl. 7, fig. 112. Sphaeroidinellopsis seminulina seminulina (Schwager) Kennett and Srinivasan, 1983, p. 206, pl. 51, figs. 1 and 6-8.

Stratigraphic range: Cores $130-806 \mathrm{~B}-51 \mathrm{X}-\mathrm{CC}$ to $-10 \mathrm{H}-\mathrm{CC}$ (base of N11-lower N19/N20).

Remarks: Between three and four chambers in the final whorl are distinguishable through the cortex. The cortex is complete. The aperture is umbilical and irregular in shape. In umbilical view, specimens with only three chambers in the final whorl appear triangular in outline.

Similar species: Sphaeroidinellopsis seminulina is more lobate than $S$. paenedehiscens, but it is not as lobate as S. kochii. S. kochii often has more chambers, and the aperture tends to be much larger than $S$. seminulina. Juveniles that have not yet developed a cortex may resemble Globigerinoides sacculifer.

\section{Streptochilus spp. Brönnimann and Resig}

Streptochilus Brönnimann and Resig, 1971, p. 1288, pl. 51, figs. 1-4; Kennett and Srinivasan, 1983, p. 21, pl. 1, figs. 2 and 6-8.

Stratigraphic range: Cores 130-806B-6IX-5 to -2H-5 (top of N6-upper N22/N23).

Remarks: Hemleben et al. (1989) refer to the modern species as Streptochilus globigerus, whereas Kennett and Srinivasan (1983) call it S. tokelauae, after Brönniman and Resig (1971). S. globigerum is a middle Miocene to lower Pliocene species distinguished by its "globose chambers and distinctly rugose test surface" (Kennett and Srinivasan, 1983). At Site 806, rugose specimens disappear above Core 130-806B-13H-2 (lower Pliocene Zone N19/N18), and members of the genus are not found again until Core 130-806B-11H-5 (midPliocene, Zone N20/N19), where they are the smooth, perforate $S$. globigerus/tokelauae form. It is not found above Core 130-06B-2H-5.
Tenuitella clemenciae (Bermudez)

Turborotalia clemenciae Bermudez, 1961, p. 1321, pl. 17, figs. 10a-b. Globorotalia (Tenuitella) clemenciae (Bermudez) Kennett and Srinivasan, 1983, p. 164, pl. 40, figs. 7-9.

Tenuitella clemenciae (Bermudez) Qianyu, 1987, p. 309, pl. 2, fig. 9.

Stratigraphic range: Cores $130-806 \mathrm{~B}-72 \mathrm{X}-\mathrm{CC}$ to $-39 \mathrm{X}-\mathrm{CC}$ (mid N4bupper N14).

Similar species: Tenuitellinata angustiumbilicata has an umbilical aperture and a more open umbilicus.

\section{Tenuitella munda (Jenkins) \\ Plate 1, Fig. 5}

Globorotalia munda Jenkins, 1966, p. 1121, fig. 14, nos. 126-133, pl. 13 , nos. 152-156.

Globorotalia (Tenuitella) munda (Jenkins) Kennett and Srinivasan, 1983, p. 162, pl. 39, figs. 5-7.

Tenuitella munda (Jenkins) Qianyu, 1987, p. 310, pl. 2, fig. 13.

Stratigraphic range: Cores 130-806B-78X-1 to $75 \mathrm{X}-2$ (N4a-lower N4b). Remarks: This small, four-chambered taxon is very rare in Hole 806B.

Similar species: Tenuitella munda is smaller than Globigerinella obesa and has a microperforate wall as compared with the finely macroperforate wall of $G$. obesa.

\section{Tenuitellinata angustiumbilicata (Bolli)} Plate 1, Fig. 9

Globigerina ciperoensis angustiumbilicata Bolli, 1957, p. 109, pl. 22, figs. $12 \mathrm{a}-13 \mathrm{c}$

Tenuitellinata angustiumbilicata (Bolli) Qianyu, 1987, p. 311, pl. 2, figs. 15 and $17-19$.

Stratigraphic range: Cores $130-806 \mathrm{C}-60 \mathrm{X}-\mathrm{CC}$ to $130-806 \mathrm{~B}-37 \mathrm{X}-5$ (upper P22-lower N16).

Remarks: This very small species is occasionally common in the lower Miocene.

Similar species: Tenuitellinata angustiumbilicata differs from Tenuitella clemenciae in possessing an umbilical, rather than an extraumbilical-umbilical aperture. $T$. angustiumbilicata differs from Globigerina quinqueloba in possessing a microperforate, rather than a macroperforate, test and in lacking the characteristic apertural flap of the latter taxon.

\section{Turborotalita humilis (Brady)}

Truncatulina humilis Brady, 1884, p. 36, pl. 8, fig. 1 (lectotype).

Turborotalita humilis (Brady) Kennett and Srinivasan, 1983, p. 167, pl. 41, figs. 1 and $3-5$.

Stratigraphic range: Cores 130-806B-61X-CC to -1H-2 (base of N6-top of N22/N23).

Similar species: $T$. humilis differs from Globigerina quinqueloba in its more oblate shape and more numerous chambers in the final whorl (typically six to seven).

\section{ACKNOWLEDGMENTS}

R.M.L. would like to thank the crew, marine technicians, and fellow scientific staff of Leg 130 for an enjoyable, interesting, and productive experience. In particular, he thanks fellow shipboard foraminiferal workers Johanna Resig and Richard Corfield for stimulating taxonomic discussions and fellow "midnight to noon" paleo lab partners Toshi Takayama and Kozo Takahashi for the enjoyable company. We thank Bill Berggren for discussions at the microscope concerning Neogene taxonomy and biostratigraphy. We also acknowledge helpful discussions with D. Graham Jenkins, Gerta Keller, and Jim Kennett. Thanks to an "anonymous" referee for the pointed and helpful comments on the manuscript. This research was supported by a USSAC grant for post-cruise research. Thanks to Maxine Schmidt for laboratory assistance. 


\section{REFERENCES*}

Barrera, E., Keller, G., and Savin, S.M., 1985. Evolution of the Miocene ocean in the eastern North Pacific as inferred from oxygen and carbon isotopic ratios of foraminifera. In Kennett, J.P. (Ed.), The Miocene Ocean: Paleoceanography and Biogeography. Mem.-Geol. Soc. Am., 163:83-102.

Barron, J.A., 1989. The late Cenozoic stratigraphic record and hiatuses of the northeast Pacific: results from the Deep Sea Drilling Project. In Winterer, E.L., Hussong, D.M., and Decker, R.W. (Eds.), The Eastern Pacific Ocean and Hawaii. Geol. Soc. Am., Geology of North America Ser. (Vol. N), 311-322.

Barron, J.A., Keller, G., and Dunn, D.A., 1985. A multiple microfossil biochronology for the Miocene. In Kennett, J.P. (Ed.), The Miocene Ocean: Paleoceanography and Biogeography. Mem.-Geol. Soc. Am., 163:21-36.

Bé, A.W.H., 1977. An ecological, zoogeographic and taxonomic review of Recent planktonic foraminifera. In Ramsay, A.T.S. (Ed.), Oceanic Micropaleontology (Vol. 1): New York (Academic Press), 1-100.

Bé, A.W.H., and Hutson, W.H., 1977. Ecology of planktonic foraminifera and biogeographic patterns of life and fossil assemblages in the Indian Ocean. Micropaleontology, 23:369-414.

Bé, A.W.H., and Tolderlund, D.S., 1971. Distribution and ecology of living planktonic foraminifera in surface waters of the Atlantic and Indian Oceans. In Funnel, B.M. and Riedel, W.R. (Eds.), The Micropaleontology of Oceans: New York (Cambridge Univ. Press), 105-149.

Berggren, W.A., 1973. The Pliocene time-scale calibration of planktonic foraminiferal and calcareous nannoplankton zones. Nature, 243:391-397.

Berggren, W.A., Kent, D.V., and Flynn, J.J., 1985a. Jurassic to Paleogene: Part 2. Paleogene geochronology and chronostratigraphy. In Snelling, N.J. (Ed.), The Chronology of the Geological Record. Geol. Soc. London Mem., 10:141-195.

Berggren, W.A., Kent, D.V., and Van Couvering, J., 1985b. The Neogene: Part 2. Neogene chronology and chronostratigraphy. In Snelling, N.J. (Ed.), The Geochronology and the Geological Record. Geol. Soc. London Mem., $10: 211-260$

Berggren, W.A., and Miller, K.G., 1988. Paleogene tropical foraminiferal biostratigraphy and magnetobiochronology. Micropaleontology, 34:362-380.

Blow, W.H., 1969. Late middle Eocene to Recent planktonic foraminiferal biostratigraphy. In Brönnimann, P., and Renz, H.H. (Eds.), Proc. 1st Int. Conf. Planktonic Microfossils, Geneva, 1967, 1:199-421.

Bolli, H.M., 1957. Planktonic foraminifera from the Oligocene-Miocene Cipero and Lengua Foramations of Trinidad, B.W.I. U.S. Nat. Mus. Bull., 215:97-103.

, 1970. The foraminifera of Sites 23-31, Leg 4. In Bader, R.G., Gerard, R.D., et al., Init. Repts. DSDP, 4: Washington (U.S. Govt. Printing Office), 577-643.

Bolli, H.M., Loeblich, A.R., and Tappan, H., 1957. Planktonic foraminiferal families Hantkeninidae, Orbulinidae, Globorotaliidae and Globotruncanidae. U.S. Nat. Mus. Bull., 215:3-50.

Bolli, H.M., and Premoli Silva, I., 1973. Oligocene to Recent planktonic foraminifera and stratigraphy of the Leg 15 sites in the Caribbean Sea. In Edgar, N.T., Saunders, J.B., et al., Init. Repts. DSDP, 15: Washington (U.S. Govt. Printing Office), 475-497.

Bolli, H.M., and Saunders, J.B., 1985. Oligocene to Holocene low latitude planktic foraminifera. In Bolli, H.M., Saunders, J.B., and Perch-Nielsen, K. (Eds.), Plankton Stratigraphy: New York (Cambridge Univ. Press), 155-262.

Brönnimann, P., and Resig, J., 1971. A Neogene Globigerinacean biochronologic time-scale of the southwestern Pacific: DSDP Leg 7. In Winterer, E.L., Riedel, W.R., et al., Init. Repts. DSDP, 7, Pt. 2: Washington (U.S. Govt. Printing Office), 1235-1470.

Buzas, M.A., 1979. The measurement of species diversity. In Lipps, J.H., Berger, W.H., Buzas, M.A., Douglas, R.G., Ross, C.A. (Eds.), Foraminiferal Ecology and Paleoecology. SEPM Short Course, 6:3-10.

Chaproniere, G.C.H., 1988. Globigerina woodi from the late Oligocene and early Miocene of southeastern Australia. J. Foraminiferal Res., 18:124-129.

Delacroix, T., Eldin, G., and Hénin, C., 1987. Upper ocean water masses and transports in the western tropic Pacific $\left(165^{\circ} \mathrm{E}\right)$. Phys. Oceanogr., $17: 2248-2262$.

* Abbreviations for names of organizations and publication titles in ODP reference lists follow the style given in Chemical Abstracts Service Source Index (published by American Chemical Society).
Dowsett, H.J., 1988. Diachrony of late Neogene microfossils in the southwest Pacific Ocean: application of the graphic correlation method. Paleoceanography, 3:209-222.

- 1989. Application of the graphic correlation method to Pliocene marine sequences. Mar. Micropaleontol., 14:3-32.

Duplessy, J.C., Bé, A.W.H., and Blanc, P.L., 1981. Oxygen and carbon isotopic composition and biogeographic distribution of planktonic foraminifera in the Indian Ocean. Palaeogeogr., Palaeoclimatol., Palaeoecol., 33:9-46.

Fairbanks, R.G., Sverdlove, M., Free, R., Wiebe, P.H., and Bé, A.W.H., 1982. Vertical distribution and isotopic fractionation of living planktonic foraminifera from the Panama Basin. Nature, 298:841-844.

Fairbanks, R.G., and Wiebe, P.H., 1980. Foraminifera and cholorphyll maximum: vertical distribution, seasonal succession, and paleoceanographic significance. Science, 209:1524-1526.

Haq, B.U., 1980. Biogeographic history of Miocene calcareous nannoplankton and paleoceanography of the Atlantic Ocean. Micropaleontology, 26:414-443.

, 1984. Paleoceanography: a synoptic overview of 200 million years of ocean history. In Haq, B.U., and Milliman, J.D., Marine Geology and Oceanography of Arabian Sea and Coastal Pakistan: New York (Van Nostrand Reinhold).

Hemleben, C., Spindler, M., and Anderson, O.R., 1989. Modern Planktonic Foraminifera: New York (Springer-Verlag).

Hess, J., Stott, L.D., Bender, M.L., Kennett, J.P., and Schilling, J.-G., 1989. The Oligocene marine microfossil record: age assessments using strontium isotopes. Paleoceanography, 4:655-679.

Jenkins, D.G., 1960. Planktonic foraminifera from the Lakes Entrance oil shaft, Victoria, Australia. Micropaleontology, 6:345-371.

Jenkins, D.G., and Orr, W.N., 1972. Planktonic foraminiferal biostratigraphy of the eastern equatorial Pacific: DSDP Leg 9. In Hays, J.D., et al., Init. Repts. DSDP, 9: Washington (U.S. Govt. Printing Office), 1057-1196.

Jenkins, D.G., Saunders, J.B., and Cifelli, R., 1981. The relationship of Globigerinoides bisphericus Todd 1954 to Praeorbulina sicana (de Stefani) 1952. J. Foraminiferal Res., 11:262-267.

Keigwin, L.D., Jr., 1978. Pliocene closing of the Panama isthmus based on biostratigraphic evidence from nearby Pacific Ocean and Caribbean cores. Geology, 6:630-634.

Keller, G., 1981a. Origin and evolution of the genus Globigerinoides in the early Miocene of the northwestern Pacific, DSDP Site 292. Micropaleontology, 27:292-304.

- 1981b. The genus Globorotalia in the Early Miocene of the equatorial and northwestern Pacific. J. Foraminiferal Res., 11:118-132.

, 1981c. Planktonic foraminiferal faunas of the equatorial Pacific suggest Early Miocene origin of present oceanic circulation. Mar. Micropaleontol., 6:269-295.

, 1984. The Oligocene/Miocene boundary in the equatorial Pacific. Riv. Ital. Paleontol. Stratigr., 89:529-556.

, 1985. Depth stratification of planktonic foraminifers in the Miocene ocean. In Kennett, J.P., The Miocene Ocean: Paleoceanography and Biogeography. Mem.-Geol. Soc. Am., 163:83-102.

Keller, G., and Barron, J.A., 1983. Paleoceanographic implication of Miocene deep-sea hiatuses. Geol. Soc. Am. Bull., 94:590-613.

, 1987. Paleodepth distribution of Neogene deep-sea hiatuses. Paleoceanography, 2:697-713.

Kennett, J.P., Keller, G., and Srinivasan, M.S., 1985. Miocene planktonic foraminiferal biogeography and paleoceanographic development of the Indo-Pacific region. In Kennett, J.P. (Ed.), The Miocene Ocean: Paleoceanography and Biogeography. Mem.-Geol. Soc. Am., 163:197-236.

Kennett, J.P., and Srinivasan, M.S., 1983. Neogene Planktonic Foraminifera: A Phylogenetic Atlas: Stroudsburg, PA (Hutchinson Ross).

Kroenke, L.W., Berger, W.H., Janecek, T.R., et al., 1991. Proc. ODP, Init. Repts., 130: College Station, TX (Ocean Drilling Program).

Lamb, J.L., and Beard, J.H., 1972. Late Neogene planktonic foraminifers in the Caribbean, Gulf of Mexico, and Italian stratotypes. Univ. of Kansas Paleontol. Contrib., Article 57 (Protozoa 8).

Levitus, S., 1982. Climatological atlas of the world ocean. NOAA Prof. Pap., 13.

Orr, W.N., and Jenkins, D.G., 1980. Eastern equatorial Pacific Pliocene-Pleistocene biostratigraphy. In Sliter, W.V. (Ed.), Studies in Marine Micropaleontology and Paleoecology: A Memorial to Orville L. Bandy. Spec. Publ. Cushman Found. Foraminiferal Res., 19:278-286.

Parker, F.L., 1962. Planktonic foraminiferal species in Pacific sediments. Micropaleonotology, 8:219-254,

, 1967. Late Tertiary biostratigraphy (planktonic foraminifera) of tropical Indo-Pacific deep-sea cores. Bull. Am. Paleontol., 52:115-208. 
Pickard, G.E., and Emery, W.J., 1990. Descriptive Physical Oceanography: An Introduction: New York (Pergamon Press).

Pisias, N.G., and Prell, W.L., 1985. Changes in calcium carbonate accumulation in the equatorial Pacific during the Late Cenozoic: evidence from HPC Site 572. In Sundquist, E.T., and Broecker, W.S. (Eds.), The Carbon Cycle and Atmospheric $\mathrm{CO}_{2}$ : Natural Variations Archean to Present. Am. Geophys. Union, 443-454.

Poag, C.W., 1972. Neogene planktonic foraminiferal biostratigraphy of the western North Atlantic: DSDP Leg 11. In Hollister, C.D., Ewing, J.I., et al., Init. Repts. DSDP, 9: Washington (U.S. Govt. Printing Office), 483-543.

Qianyu, L., 1987. Origin, phylogenetic development and systematic taxonomy of the Tenuitella plexus (Globigerinitidae, Globigerininina). J. Foraminiferal Res., 17:298-320.

Ravelo, A.C., Fairbanks, R.G., and Philander, S.G.H., 1990. Reconstructing tropical Atlantic hydrography using planktonic foraminifera and an ocean model. Paleoceanography, 5:409-431.

Saito, T., 1985. Planktonic foraminiferal biostratigraphy of eastern equatorial Pacific sediments, DSDP Leg 85. In Mayer, L., Theyer., Thomas, E., et al., Init. Repts. DSDP, 85: Washington (U.S. Govt. Printing Office), 621-654.

Sikes, E.L., Keigwin, L.D., and Curry, W.B., 1991. Pliocene paleoceanography: circulation and oceanographic changes associated with the $2.4 \mathrm{Ma}$ glacial event. Paleoceanography, 6:245-258.

Spezzaferri, S., 1991. Evolution and taxonomy of the Paragloborotalia kugleri (Bolli) lineage. J. Foraminiferal Res., 21:313-318.

Srinivasan, M.S., and Kennett, J.P., 1981a. A review of Neogene planktonic foraminiferal biostratigraphy: applications in the equatorial and South Pacific. In Warme, J.E., Douglas, R.G., Winterer, E.L. (Eds.), The DeepSea Drilling Project: A Decade of Progress. Spec. Publ.-Soc. Econ. Paleontol. Mineral., 32:395-432.

, 1981b. Neogene planktonic foraminiferal biostratigraphy and evolution: equatorial to subantarctic South Pacific. Mar. Micropaleontol., 6:499-533.
Stainforth, R.M., Lamb, J.L., Luterbacher, H-P., Beard, J.H., and Jeffords, R.M., 1975. Cenozoic planktonic foraminiferal zonation and characteristics of index forms. Univ. of Kansas Publ., Article 62.

Stone, S.M., and Keller, G., 1985. Planktonic foraminiferal biostratigraphy of the Middle America Trench region, DSDP Leg 84, In von Huene, R., Aubouin, J., et al., Init. Repts. DSDP, 84: Washington (U.S. Govt. Printing Office), $419-472$.

Theyer, F., Vincent, E., and Mayer, L.A., 1989. Sedimentation and paleoceanography of the central equatorial Pacific. In Winterer, E.L., Hussong, D.M., and Decker, R.W. (Eds.), The Eastern Pacific Ocean and Hawaii. Geol. Soc. Am., Geology of North America Ser. (Vol. N), 347-373.

Thompson, P.R., and Sciarillo, J.R., 1978. Planktonic foraminiferal biostratigraphy in the equatorial Pacific. Nature, 275:29-33.

Thunell, R.C., and Belyea, P., 1982. Neogene planktonic foraminiferal biogeography in the Atlantic Ocean. Micropaleontology, 28:381-398.

Webb, P.-N., and Harwood, D.M., 1991. Late Cenozoic glacial history of the Ross Embayment, Antarctica. Quat. Sci. Rev., 10:215-223.

Wei, K.-Y., and Kennett, J.P., 1986. Taxonomic evolution of Neogene planktonic foraminifera and paleoceanographic relations. Paleoceanography, $1: 67-84$.

Wright, J.D., and Thunell, R.C., 1988. Neogene planktonic foraminiferal biogeography and paleoceanography of the Indian Ocean. Micropaleontology, 34:193-215.

Date of initial receipt: 31 January 1992

Date of acceptance: 4 September 1992

Ms 130B-010 


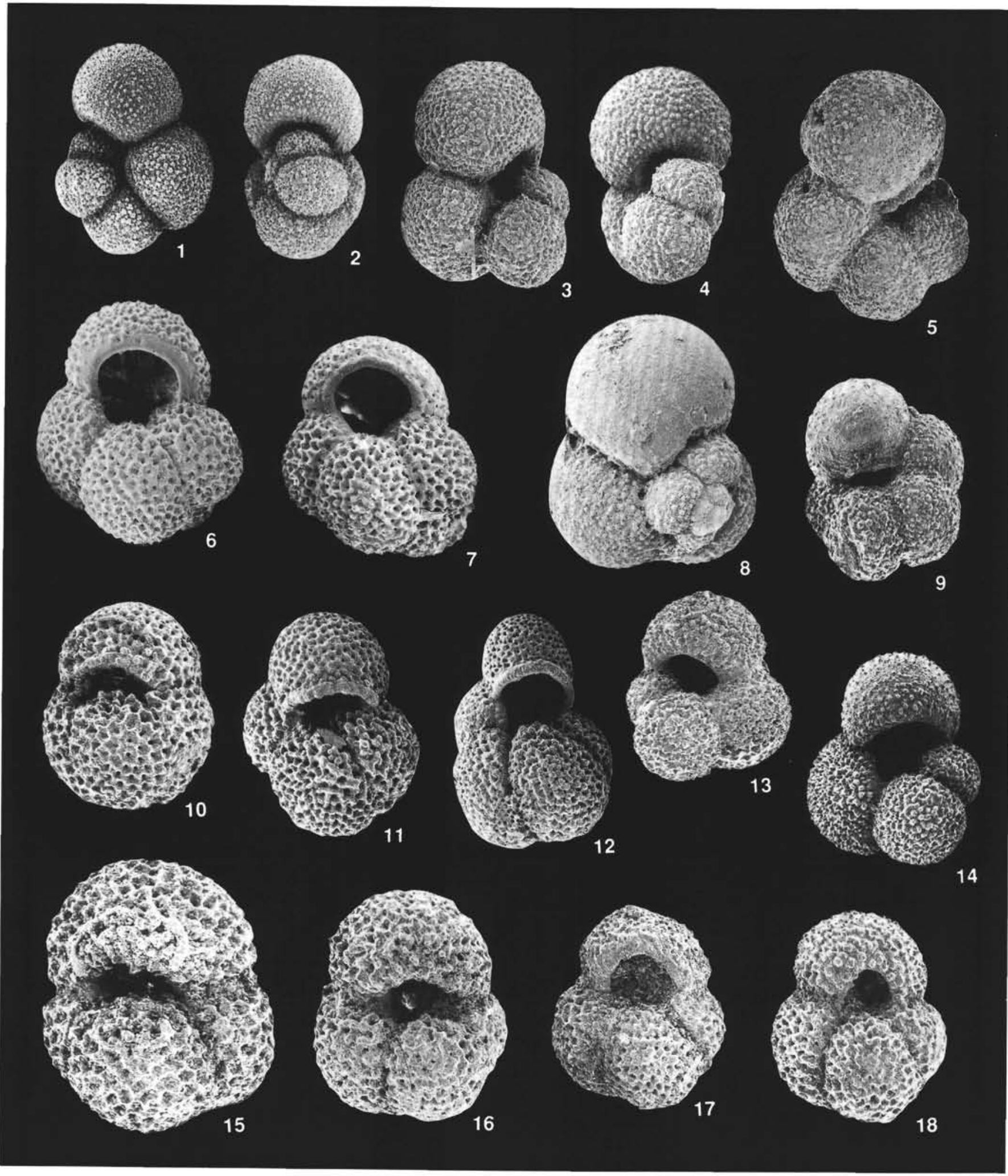

Plate 1. 1-2. Globigerinella aequilateralis. Sample 130-806B-29H-6, 30-32 cm, $\times 70$. 3-4. Globigerinella obesa. Sample 130-806B-46X-CC, $\times 100$. 5. Tenuitella munda. Sample 130-806B-78X-1, 30-32 cm, $\times 200$. 6. Globigerina apertura. Sample 130-806B-29H-5, 30-32 cm, $\times 150$. 7. Globigerina decoraperta. Sample 130-806B-24H-2, 24-26 cm, $\times 150$. 8. Candeina nitida. Sample $130-806 \mathrm{~B}-31 \mathrm{H}-2,32-34 \mathrm{~cm}, \times 150$ (FO). 9. Tenuitellinata angustiumbilicata. Sample 130-806B-72X-2, 30-32 cm, $\times 200$. 10-11. Globigerina druryi. (10) Sample 130-806B-56X-4, 31-33 cm, $\times 150$; (11) Sample 130-806B-53X-2, 40-42 $\mathrm{cm}, \times 150$. 12. Globigerina nepenthes. Sample 130-806B-37X-3, 32-34 cm, $\times 100$. 13-14. Globigerina bulloides. (13) Sample 130-806B-57X-CC, $\times 150$; (14) Sample $130-806 \mathrm{~B}-29 \mathrm{H}-5,30-32 \mathrm{~cm}, \times 100$. 15. Globigerina connecta. Sample $130-806 \mathrm{~B}-72 \mathrm{X}-2,30-32 \mathrm{~cm}, \times 200$. 16. Globigerina cf. G. woodi. Sample 130-806B-76X-CC, $\times 150$. 17-18. Globigerina woodi. (17) Sample 130-806B-72X-2, 30-32 cm, $\times 150$; (18) Sample 130-806B-65X-5, 31-33 cm, $\times 150$. 


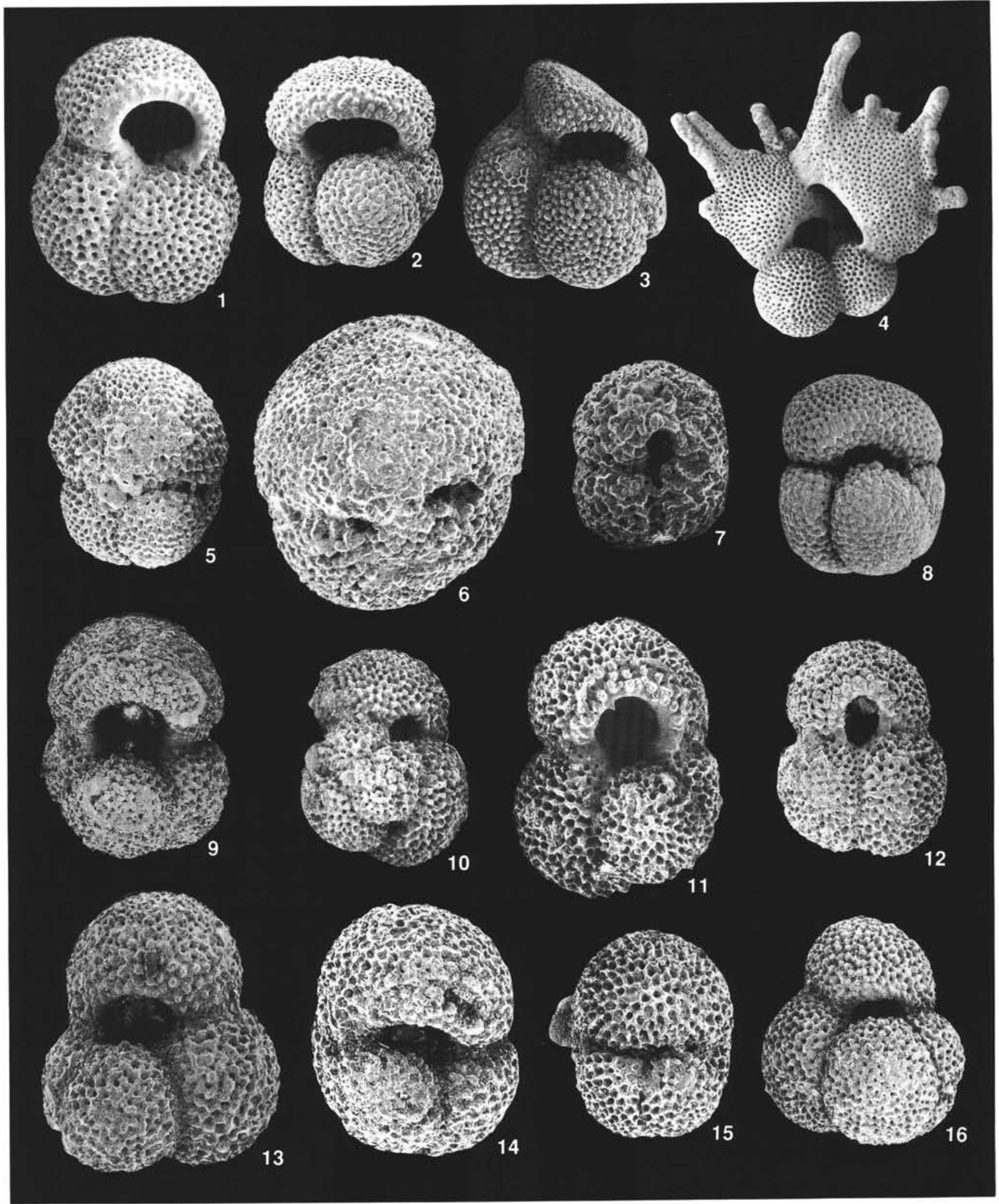

Plate 2. 1-2. Globigerinoides obliquus. (1) Sample 130-806B-41X-CC, $\times 150$; (2) Sample 130-806B-33H-2, 30-32 cm, $\times 100$. 3. Globigerinoides extremus. Sample 130-806B-34H-5, 32-34 cm, $\times 70$. 4. Globigerinoides fistulosus. Sample 130-806B-5H-5, 52-54 cm, $\times 45$. 5-6. Praeorbulina sicana. (5) Sample 130-806B-59X-5, 32-34 cm, $\times 100$ (FO); (6) Sample 130-806B-58X-2, 33-35 cm, $\times 100 . \quad$ 7. Globigerinoides diminutus. Sample 130-806B-57X-CC, $\times 150 . \quad 8$ Globigerinoides conglobatus. Sample 130-806B-18H-1,30-32 cm, $\times 70$. 9-11. Globigerinoides altiapertura. (9) Sample 130-806B-69X-CC, $\times 100$; (10) Sample 130-806B-65X-5, 31-33 cm, ×100; (11) Sample 130-806B-64X-2, 27-29 cm, $\times 150$. 12. Globigerinoides subquadratus. Sample 130-806B-61X-6, 31-33 cm, $\times 100$. 13. Globigerinoides primordius. Sample $130-806 \mathrm{~B}-74 \mathrm{X}-3,28-30 \mathrm{~cm}, \times 150$. 14-15. Globigerinoides triloba. (14) Sample 130-806B-70X-CC, $\times 150$; (15) Sample 130-806B-62X-4, 31-33 cm, $\times 100$. 16. Globigerinoides sacculifer. Sample 130-806B-69X-4, 31-33 cm, $\times 100$ (early form). 


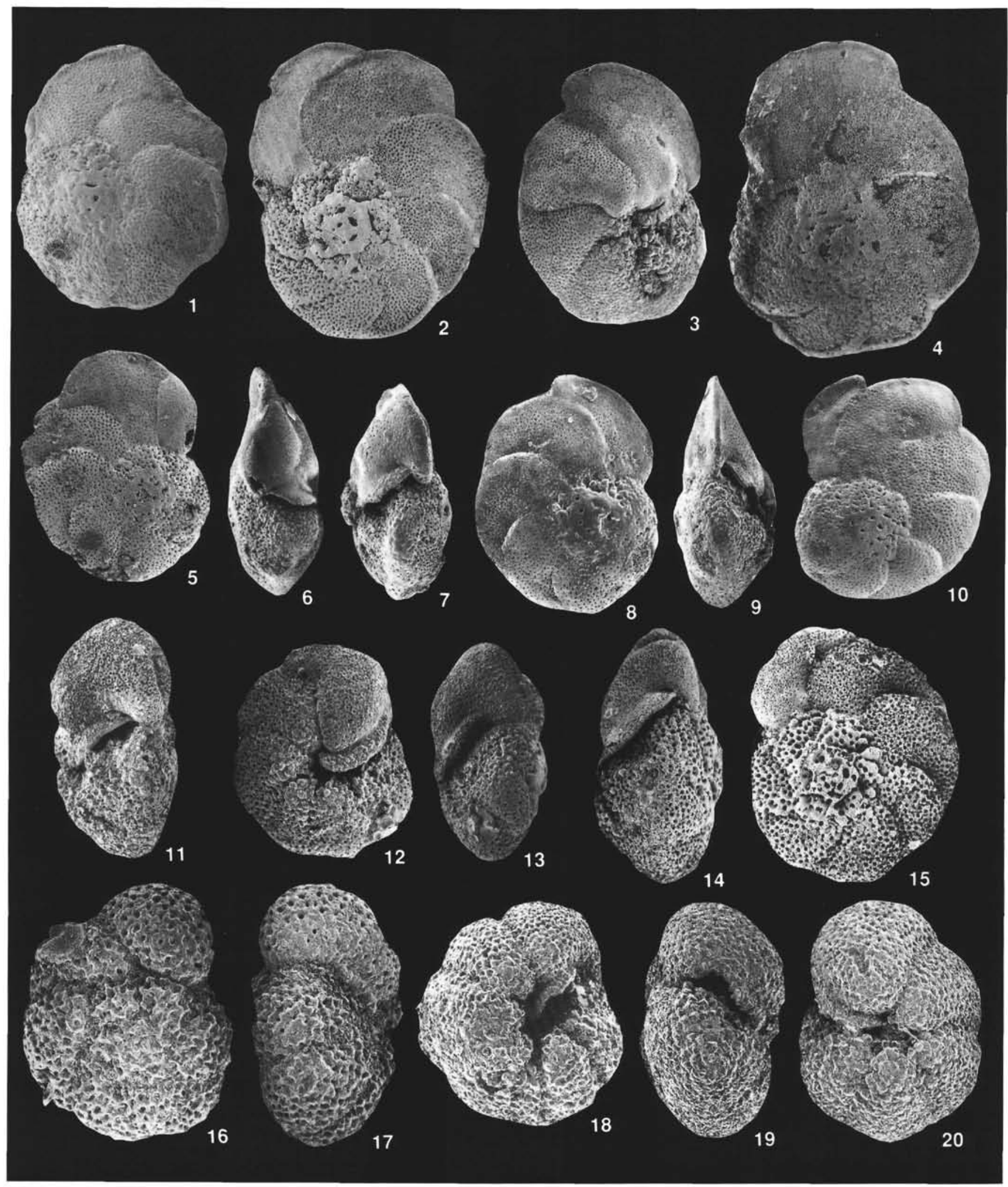

Plate 3. 1-4. Globorotalia fohsi s.l. (1) Sample 130-806B-48X-2, 34-36 cm, ×70; (2) Sample 130-806B-47X-CC, $\times 70$; (3) Sample 130-806B-46X-CC, $\times 70$; (4) Sample 130-806B-45X-5, 34-36 cm, $\times 70$. 5-7. Globorotalia praefohsi. (5-6) Sample 130-806B-51X-2, 29-31 cm, $\times 70$; (7) Sample 130-806B-49X-CC, $\times 70$. 8-10. Globorotalia praefohsi-fohsi transition; (8-9) Sample 130-806B-48X-CC, $\times 70$; (10) Sample 130-806B-48X-CC, $\times 70$. 11, 19-20. Globorotalia peripheroronda. (11) Sample 130-806B-53X-4, 30-32 cm, ×100; (19-20) Sample 130-806B-63X-3, 35-37 cm, $\times 150$. 12-13. Globorotalia peripherorondaperipheroacuta transition; Sample 130-806B-53X-4,30-32 cm, $\times 100$. 14-15. Globorotalia peripheroacuta. Sample 130-806B-52X-5,31-33 cm, $\times 100 . \quad$ 16-18. Globorotalia kugleri. (16-17) Sample 130-806B-78-CC, $\times 200$ (FO); (18) Sample 130-806B-74X-3, 28-30 cm, ×150. 


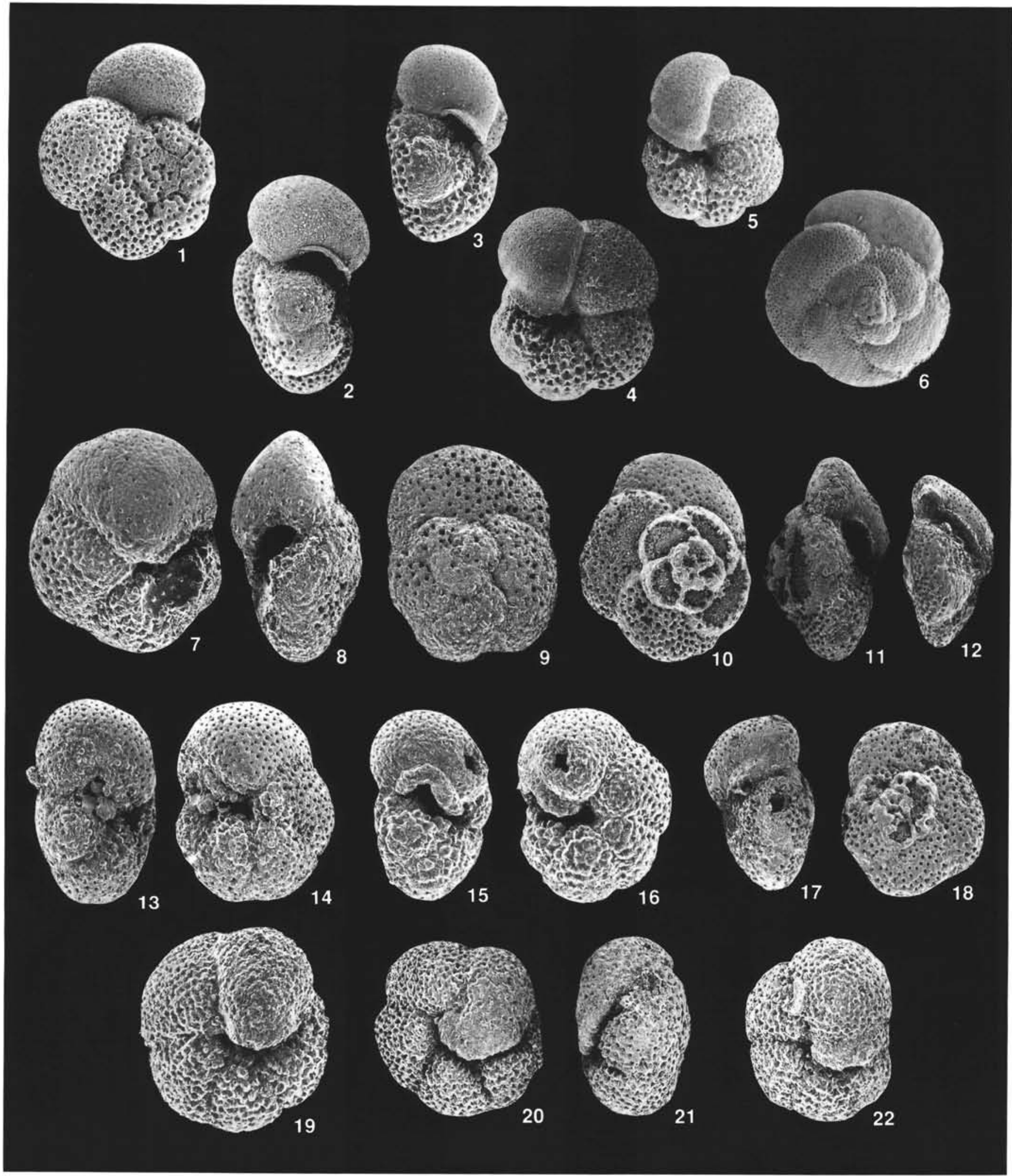

Plate 4. 1-5. Globorotalia challengeri. (1-2) Sample 130-806B-39X-1, 32-34 cm, $\times 150$; (3-4) Sample 130-806B-39X-1, 32-34 cm, $\times 150$; (5) Sample 130-806B-39X-1, 32-34 cm, $\times 150$. 6. Globorotalia scitula. Sample 130-806B-44X-4, 34-36 cm, $\times 70$. 7-11. Globorotalia praescitula. (7-8) Sample 130806B-62X-6, 32-34 cm, ×200; (9) Sample 130-806B-62X-6, 32-34 cm, $\times 200$; (10-11) Sample 130-806B-62X-3, 40-42 cm, $\times 150$. 12, 17-18. Globorotalia cf. G. miozea. (12) Sample 130-806B-56X-CC, $\times 150$; (17-18) Sample 130-806B-61X-1, 21-23 cm, $\times 150$. 13-16. Globorotalia cf. G. zealandica. (13-14) Sample 130-806B-63X-6, 31-33 cm, ×150; (15-16) Sample 130-806B-61X-1, 21-23 cm, $\times 150$. 19-22. Globorotalia birnageae. (19) Sample 130-806B-72X-CC, $\times 200$ (FO); (20-21) Sample 130-806B-71X-1, 30-32 cm, ×150; (22) Sample 130-806B-71X-1, 30-32 cm, $\times 150$. 


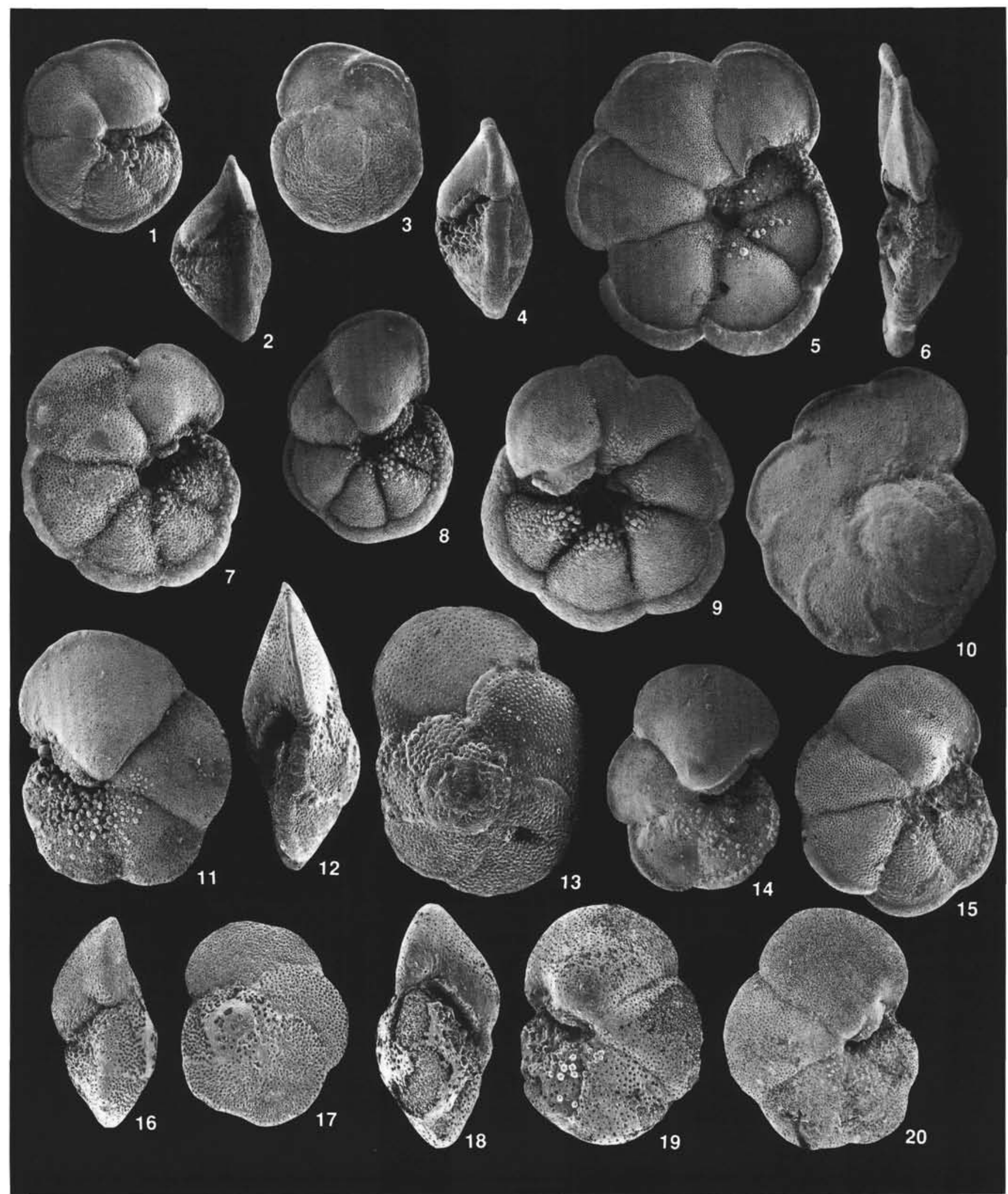

Plate 5. 1-4. Globorotalia pseudomiocenica. (1-2) Sample 130-806B-23H-CC, $\times 70$; (3-4) Sample 130-806B-23H-CC, $\times 70$. 5-6. Globorotalia cf. G. pertenuis. Sample 130-806B-22H-2, 30-32 cm, $\times 45$. 7-9, 15. Globorotalia menardii s.1. (7) Sample 130-806B-39X-2, 32-34 cm, $\times 70$; (8) Sample 130-806B25H-2, 29-31 cm, ×45; (9) Sample 130-806B-19H-4, 29-31 cm, ×45; (15) Sample 130-806B-43X-CC, $\times 70 . \quad$ 10. Globorotalia limbata. Sample 130-806B-28H-2, $35-37 \mathrm{~cm}, \times 70$. 11. Globorotalia archeomenardii-praemenardii transition; Sample $130-806 \mathrm{~B}-54 \mathrm{X}-2,31-33 \mathrm{~cm}, \times 100$. 12-14. Globorotalia praemenardii. Sample 130-806B-45X-CC, $\times 100$; (14) Sample 130-806B-44X-CC, $\times 70 . \quad$ 16-20. Globorotalia archeomenardii. (16-17) Sample 130-806B-54X-CC, $\times 100$; (18-19) Sample 130-806B-56X-2, 35-37 cm, $\times 150$ (FO); (20) Sample 130-806B-54X-CC, $\times 100$. 


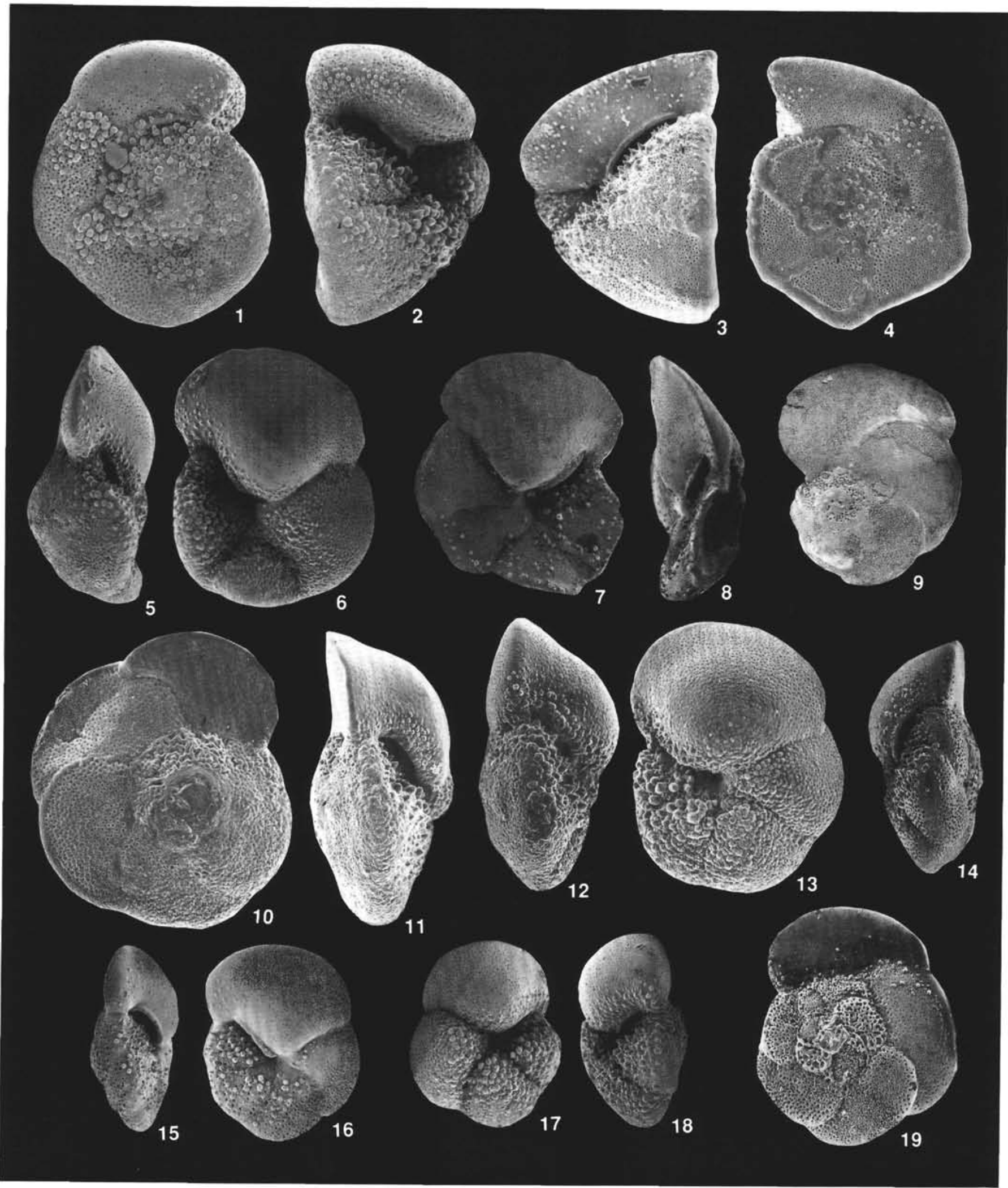

Plate 6. 1-2. Globorotalia tosaensis. Sample 130-806B-6H-2, 72-74 cm, $\times 100$. 3-4. Globorotalia truncatulinoides. Sample 130-806B-6H-5, 73-75 cm, $\times 100$ (FO). 5-9. Globorotalia margaritae. (5-6) Sample 130-806B-19H-1, 29-31 cm, $\times 70$ (FO); (7-8) Sample 130-806B-13H-2, 30-32 cm, $\times 70$; (9) Sample 130-806B-13H-2, 30-32 cm, ×70. 10-11. Globorotalia cf. G. crassula. Sample 130-806B-18H-7, 30-32 cm, $\times 100$. 12-14, 19. Globorotalia cibaoensis. (12-13) Sample 130-806B-18H-7, 30-32 cm, ×100; (14, 19) Sample 130-806B-29H-5, 30-32 cm, $\times 100$. 15-16. Globorotalia scitula. Sample 130-806B-19H-4, 29-31 cm, $\times 70$, 17-18. Globorotalia juanai. Sample 130-806B-19H-4, 29-31 cm, $\times 70$. 


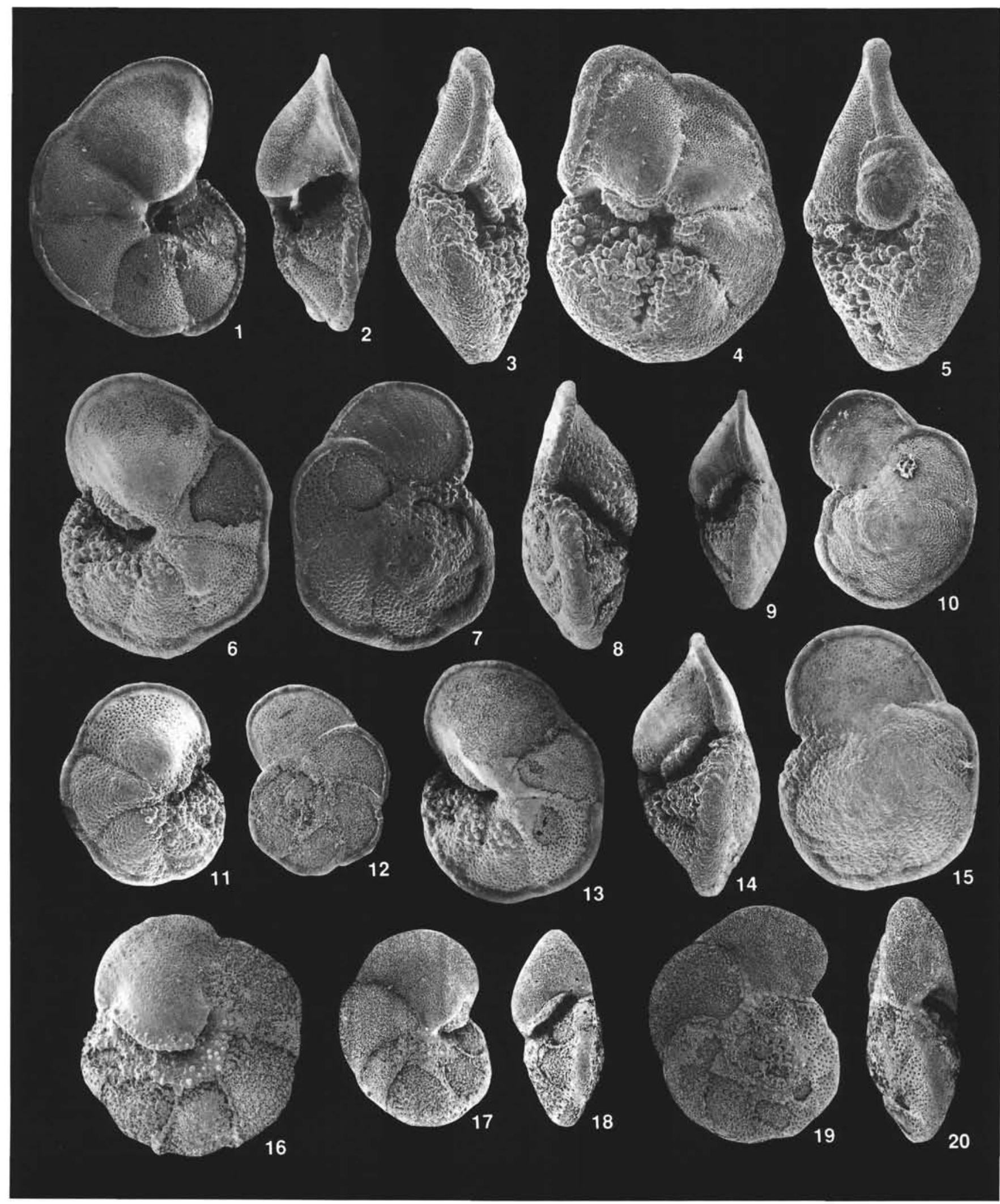

Plate 7. 1-2, 6-10. Globorotalia plesiotumida. (1-2) Sample 130-806B-24H-2, 24-26 cm, $\times 70$; (6) Sample 130-806B-29H-3, 30-32 cm, $\times 100$ (FO); (7-8) Sample 130-806B-29H-3, 30-32 cm, $\times 100$ (FO); (9-10) Sample 130-806B-26H-2, 29-31 cm, $\times 70$. 3-5. Globorotalia tumida. (3-4) Sample 130-806B-19H-3, 29-31 cm, $\times 70$ (FO); (5) Sample 130-806B-18H-4, 30-32 cm, $\times 70$. 11-15. Globorotalia merotumida. (11) Sample 130-806B-37X-3, 32-34 cm, $\times 100$; (12) Sample 130-806B-35X-CC, $\times 100$; (13) Sample 130-806B-29H-3, 30-32 cm, $\times 100$; (14-15) Sample 130-806B-30H-2, 30-32 cm, $\times 100$. 16-20. Globorotalia lenguaensis s.l. (16) Sample 130-806B-42X-CC, $\times 150$; (17-18) Sample 130-806B-26H-5, 29-31 cm, $\times 100$; (19-20) Sample 130-806B-23H-5, 27-29 cm, $\times 100$. 


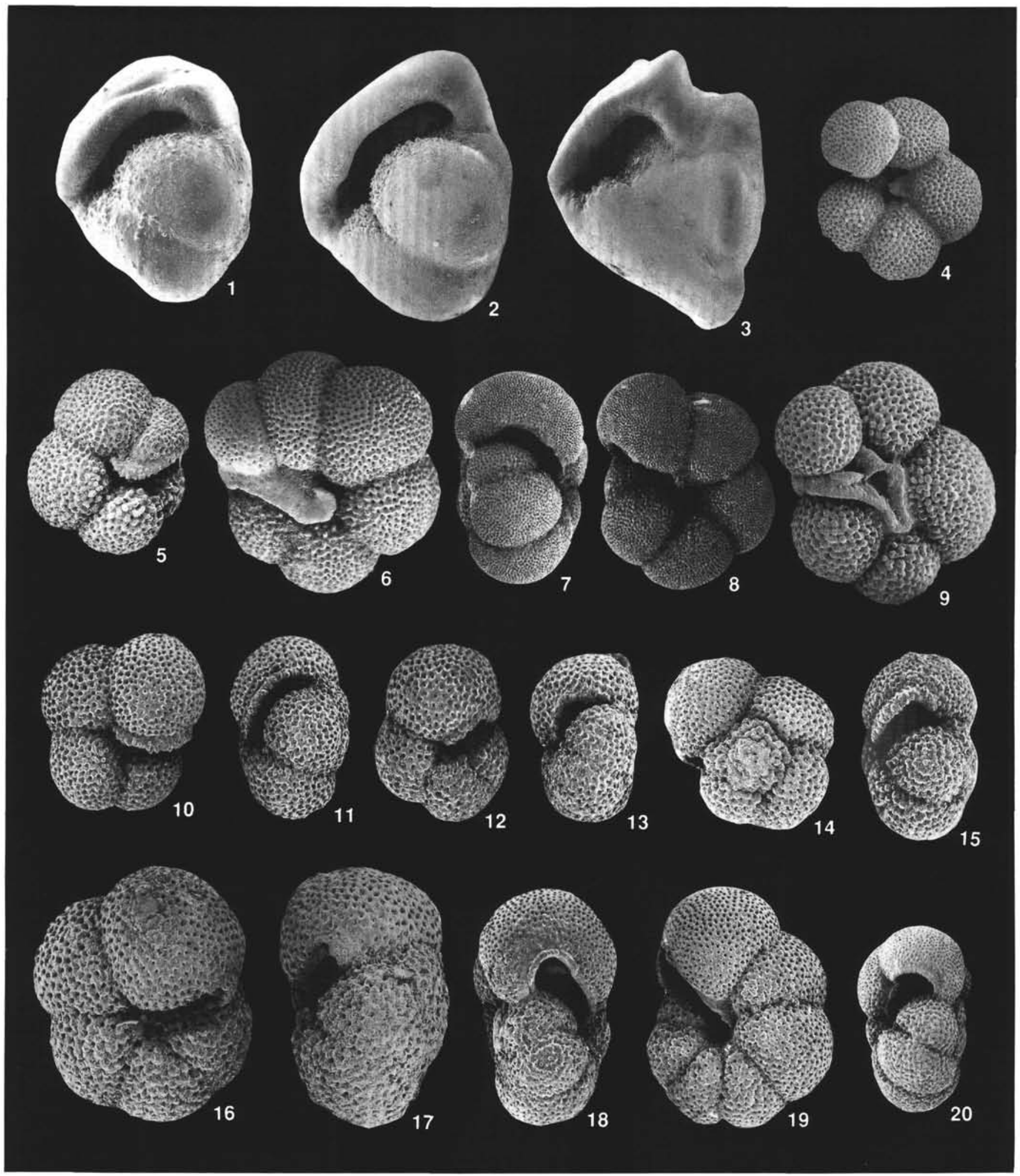

Plate 8. 1. Pulleniatina primalis. Sample $130-806 \mathrm{~B}-15 \mathrm{H}-5,29-31 \mathrm{~cm}, \times 100$. 2. Pulleniatina praespectabilis. Sample 130-806B-16H-CC, $\times 70$. 3. Pulleniatina spectabilis. Sample 130-806B-13H-2, 30-32 cm, $\times 70$. 4. Neogloboquadrina dutertrei. Sample 130-806B-17H-CC, $\times 70 . \quad$ 5. Neogloboquadrina acostaensis. Sample 130-806B-35X-CC, $\times 100$. 6. Neogloboquadrina $\mathrm{cf}$. N. acostaensis. Sample 130-806B-23H-1, $27-29 \mathrm{~cm}, \times 100$. 7-8. Neogloboquadrina humerosa. Sample 130-806B-24H-2, 24-26 cm, $\times 70$. 9. Neogloboquadrina cf. N. dutertrei. Sample 130-806B-17H-CC, $\times 100$. 10-11. Paragloborotalia nana. Sample 130-806B-63X-1, 32-34 cm, $\times 100$. 12-15. Neogloboquadrina continuosa. (12-13) Sample 130-806B-63X-6, 31-33 cm, $\times 100$; (14-15) Sample 130-806B-54X1,32-34 cm, $\times 100$. 16-20. Paragloborotalia mayeri s.l. (16-17) Sample 130-806B-76X-2,30-32 cm, $\times 150 ;(18-19)$ Sample 130-806B-63X-3,35-37 cm, $\times 100$; (20) Sample 130-806B-52X-2, 31-33 cm, $\times 70$. 

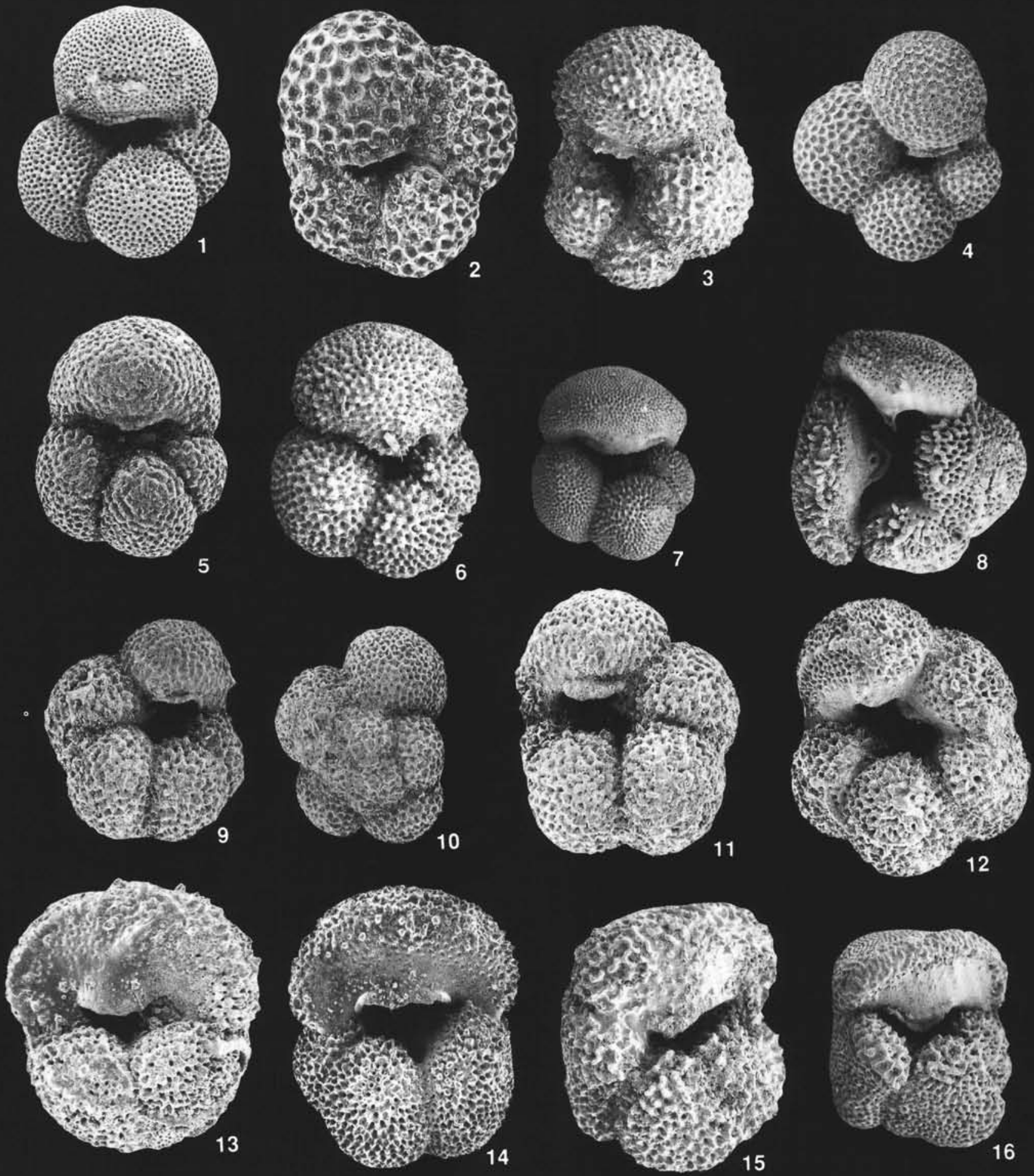

Plate 9. 1. Globoquadrina conglomerata. Sample $130-806 \mathrm{~B}-11 \mathrm{H}-2,49-51 \mathrm{~cm}, \times 70$. 2. Globorotaloides suteri. Sample 130-806B-72X-2, 30-32 cm, $\times 200$. 3. Globorotaloides variabilis. Sample $130-806 \mathrm{~B}-42 \mathrm{X}-2,32-34 \mathrm{~cm}, \times 100$. 4. Globorotaloides hexagona, Sample 130-806B-29H-4, 30-32 cm, $\times 100$. 5-7. Globoquadrina baroemoenensis. (5) Sample 130-806B-70X-CC, $\times 100$; (6) Sample 130-806B-54X-2, 31-33 cm, ×100; (7) Sample 130-806B-18H, 30-32 cm, $\times 45$. 8. Dentoglobigerina altispira. Sample $130-806 \mathrm{~B}-24 \mathrm{H}-2,24-26 \mathrm{~cm}, \times 70$. 9-11. Globoquadrina? cf. G. extans. (9) Sample 130-806B-69X-4, 31-33 cm, $\times 150$; (10) Sample 130-806B-74X-3, 28-30 cm, ×100; (11) Sample 130-806B-74X-3, 28-30 cm, $\times 150$. 12. Dentoglobigerina cf. D. altispira. Sample 130-806B-67X-CC, $\times 100$. 13. Globoquadrina binaiensis. Sample 130-806B-59X-5, 32-34 cm, $\times 100$. 14-16. Globoquadrina dehiscens. (14) Sample 130806B-63X-4, 32-34 cm, ×100; (15) Sample 130-806B-54X-2, 31-33 cm, $\times 150$; (16) Sample 130-806B-42X-3, 32-34 cm, $\times 70$. 


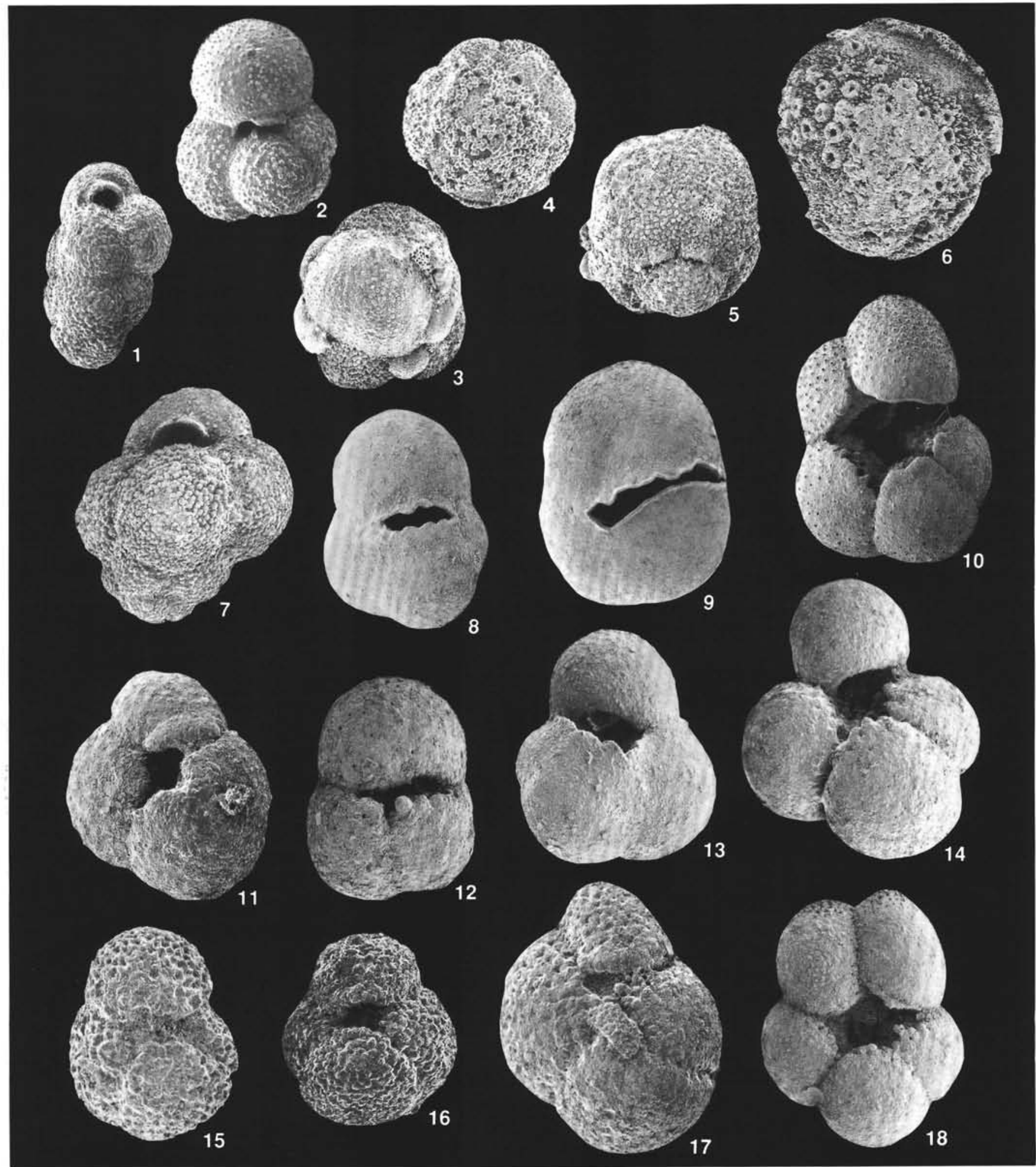

Plate 10. 1, 7. Globigerinita uvula. (1) Sample 130-806B-61X-2,29-31 cm, $\times 150$; (7) Sample 130-806B-65X-2, 31-33 cm, $\times 150$. 2. Globigerinita glutinata. Sample 130-806B-61X-2, 29-31 cm, $\times 150$. 3. Globigerinita glutinata-Globigerinatella insueta transition; Sample 130-806B-62X-CC, $\times 100$. 4-6. Globigerinatella insueta. (4) Sample 130-806B-62X-1, 33-35 cm, $\times 100$ (FO); (5) Sample 130-806B-61X-6, 31-33 cm, $\times 100$; (6) Sample 130-806B-57X-5, 36-38 cm, $\times 100$. 8, 11-13. Sphaeroidinellopsis seminulina. (8) Sample 130-806B-28H-5, 35-37 cm, $\times 70$; (11) Sample 130-806B-39X-2, 32-34 cm, $\times 100 ;(12)$ Sample 130-806B-39X-2, 32-34 cm, ×100; (13) Sample 130-806B-33H-2, 30-32 cm, $\times 70$. 9. Sphaeroidinellopsis paenedehiscens. Sample 130-806B-19H-3, 29-31 $\mathrm{cm}, \times 70 . \quad 10,14,18$. Sphaeroidinellopsis kochi. (10) Sample 130-806B-27H-2, 35-37 cm, $\times 70$; (14) Sample 130-806B-39X-CC, $\times 70$; (18) Sample 130-806B$44 \mathrm{X}-4,34-36 \mathrm{~cm}, \times 70$. 15. Globigerina druryi-Sphaeroidinellopsis disjuncta transition; Sample 130-806B-60X-2, 31-33 cm, $\times 150$. 16. Sphaeroidinellopsis disjuncta. Sample 130-806B-58X-5, 36-38 cm, $\times 100$. 17. Sphaeroidinellopsis disjuncta-S. seminulina transition. Sample 130-806B-50X-CC, $\times 100$. 